Andrews University

Digital Commons @ Andrews University

\title{
Teachers' Implementation of and Stages of Concern Regarding English Language Arts (ELA) Common Core State Standards (CCSS) in New York State
}

Alozie Augustine Ogbonna

Andrews University, ogbanna@andrews.edu

Follow this and additional works at: https://digitalcommons.andrews.edu/dissertations

Part of the Curriculum and Instruction Commons

\section{Recommended Citation}

Ogbonna, Alozie Augustine, "Teachers' Implementation of and Stages of Concern Regarding English Language Arts (ELA) Common Core State Standards (CCSS) in New York State" (2020). Dissertations. 1729.

https://digitalcommons.andrews.edu/dissertations/1729

https://dx.doi.org/10.32597/dissertations/1729

This Dissertation is brought to you for free and open access by the Graduate Research at Digital Commons @ Andrews University. It has been accepted for inclusion in Dissertations by an authorized administrator of Digital Commons@ Andrews University. For more information, please contact repository@andrews.edu. 


\begin{abstract}
TEACHERS' IMPLEMENTATION OF AND STAGES OF CONCERN REGARDING ENGLISH LANGUAGE ARTS (ELA) COMMON CORE STATE STANDARDS (CCSS) IN NEW YORK STATE
\end{abstract}

by

Alozie Augustine Ogbonna

Chair: Larry D. Burton, Ph.D. 


\title{
ABSTRACT OF GRADUATE STUDENT RESEARCH
}

\author{
Dissertation \\ Andrews University \\ College of Education and International Services
}

\section{Title: TEACHERS' IMPLEMENTATION OF AND STAGES OF CONCERN REGARDING ENGLISH LANGUAGE ARTS (ELA) COMMON CORE STATE STANDARDS (CCSS) IN NEW YORK STATE}

Name of researcher: Alozie Augustine Ogbonna

Name and degree of faculty chair: Larry D. Burton, Ph.D.

Date completed: June 2020

\section{Problem}

In the State of New York, the adoption and implementation of the Common Core State Standards (CCSS) and associated high-stakes assessments have sparked debates among educators, parents, students and politicians. Educators are concerned about its impact on students' test scores, graduation rates and school funding. With mounting accountability threats, teachers are forced to teach to the test in order to produce desirable test scores (Zimmerman, 2010, as cited in Pinar, 2012, p.17). Unfortunately, there were no studies that promoted understanding of teachers' concerns and the extent to which they were implementing the CCSS. The purpose of this study was to investigate teachers' concerns and the extent to which they were implementing the CCSS in language arts in the state of New York. 


\section{Method}

The design of this study is a non-experimental quantitative design using survey research methodology. A survey using a modified Stages of Concern Questionnaire (SoCQ) and a researcher-developed implementation of language arts core standards questionnaire were given to Grades 6-12 ELA teachers from 75 selected schools in New York state. Seventy-five teachers responded to the questionnaire with 53 useable responses. The data was analyzed using descriptive statistics and bivariate correlation.

\section{Results}

Respondents were mostly from urban/suburban schools (90.4\%). Teachers implement 13 of the 15 common core standards in language arts at least once a week $(M=4.02$ to $M=6.15)$. Levels of implementation were similar in both middle and high schools ( $\mathrm{p}>.05)$ and appear to be unrelated to number of years implementing the CCSS. Approximately half $(52.8 \%)$ were at concern stages 4 to 6 . And overall, there is no relationship between stage of concern and levels of implementation of the common core standards.

\section{Conclusions}

Teachers are adequately implementing language arts common core standards in New York. Half of the teachers' concerns are generally about how implementation of the standards affect their students and their colleagues. The other half are concerned about how implementation affects them personally. To achieve the objective of the curriculum and the Every Student Succeeds Act (ESSA), teachers must continue to receive targeted professional development in their identified areas of needs. 


\author{
Andrews University \\ College of Education and International Services
}

\title{
TEACHERS' IMPLEMENTATION OF AND STAGES OF CONCERN REGARDING ENGLISH LANGUAGE ARTS (ELA) COMMON CORE STATE STANDARDS (CCSS) IN NEW YORK STATE
}

\author{
A Dissertation \\ Presented in Partial Fulfillment \\ of the Requirements for the Degree \\ Doctor of Philosophy
}

by

Alozie Augustine Ogbonna

June 2020 


\title{
TEACHERS' IMPLEMENTATION OF AND STAGES OF CONCERN REGARDING ENGLISH LANGUAGE ARTS (ELA) COMMON CORE STATE STANDARDS (CCSS) IN NEW YORK STATE
}

\author{
A dissertation \\ presented in partial fulfillment \\ of the requirements for the degree \\ Doctor of Philosophy
}

by

Alozie Augustine Ogbonna

APPROVAL BY THE COMMITTEE:

Chair: Larry D. Burton

Member: Jimmy Kijai

Member: Grace Nwosu

Member: Sunimal Kulasekere
Alayne Thorpe, Dean, College of Education and International Services 
Dedicated to my widowed and hard-working mother, Comfort, in appreciation of her value for education and sacrifices she made to provide me the foundation to reach this academic milestone, and to my siblings who yielded to me to become the first graduate of the family. Also, I proudly dedicate this accomplishment to my dear wife, Rose, who took good care of me and our children: Chigo, Nneoma, Chisom, and Chinedum while I immersed myself in this rigorous enterprise. Thanks to my dissertation committee, my friends and family members who often inquired about my progress in the program. We have made it. 


\section{TABLE OF CONTENTS}

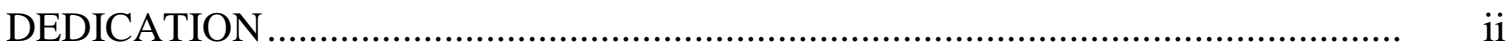

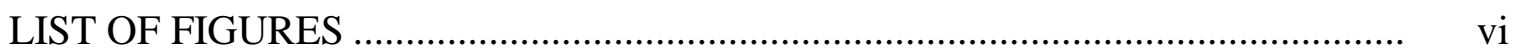

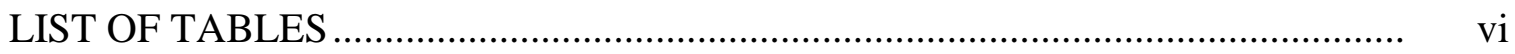

\section{Chapter}

1. INTRODUCTION ...........................................................................

Background of the Study ……………............................................... 1

Overview of Curriculum Innovation in America ............................. 1

Common Core State Standards ..................................................... 2

Statement of the Problem.............................................................. 5

Purpose of the Study ......................................................................... 8

Research Questions .................................................................... 8

The Significance of the Study ………………………………........

Theoretical and Conceptual Framework ................................................. 11

The Innovation-Decision Process ................................................ 11

Concerns-Based Adoption Model (CBAM).................................. 11

Stages of Concern (SoC) ............................................................ 14

Definition of Terms ........................................................................ 14

Delimitations of the Study …………………………......................... 17

Limitations of the Study ...................................................................... 18

Organization of the Dissertation........................................................... 18

2. REVIEW OF THE LITERATURE ........................................................ 20

The Search: Inclusion and Exclusion Criteria....................................... 20

Historical Framework of Reference ...................................................... 21

Trends in Curriculum Development .................................................... 23

The Common Core State Standards ........................................................ 24

Instructional Shifts Demanded in Common Core

State Standards ............................................................. 24

The Rationale for Common Core State Standards .......................... 25

Concerns Related to Common Core State Standards ....................... 26

Implementation/Teaching Concerns ............................................. 27

Testing and Evaluation Concerns................................................. 29

Students' Academic Success Concerns........................................... 30 
Accountability Concerns ............................................................... 32

Professional Development Concerns ............................................ 34

Government's Response................................................................. $\quad 38$

Recommendations for Implementing the Common Core

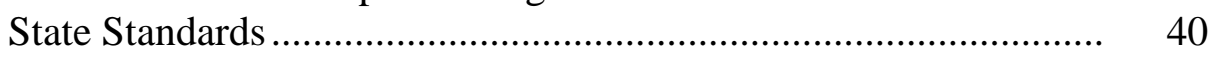

The Concerns-Based Adoption Model (CBAM) .................................. 41

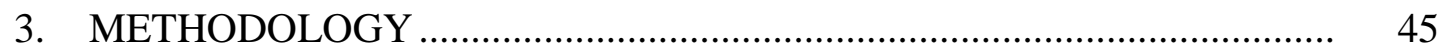

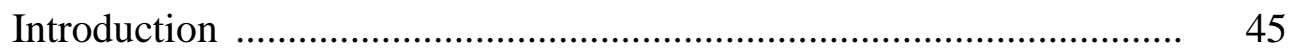

Research Questions ........................................................................ 45

Research Design ......................................................................... 46

Population and Sample.......................................................... 47

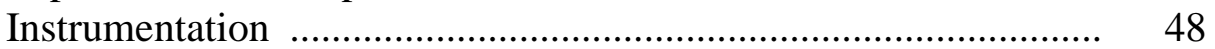

The Stages of Concern Questionnaire..................................... 48

Extent of Implementation Questionnaire ................................ 49

Validity and Reliability ..................................................... $\quad 50$

Procedures .......................................................................... 54

Data Analysis ........................................................................ 55

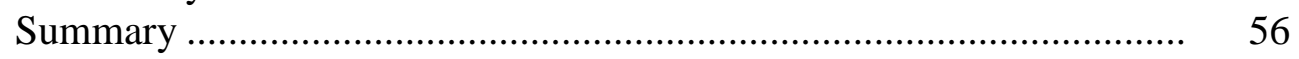

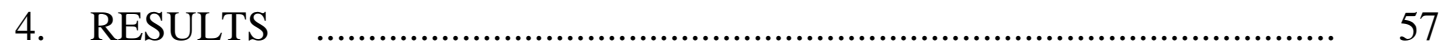

Introduction ........................................................................... 57

Description of Respondents .............................................................. 57

Analyses of Research Questions .......................................................... $\quad 59$

Research Question 1 .............................................................. 59

Research Question 2 .............................................................. 65

Research Question 3 ........................................................... 72

Research Question 4 ................................................................ 81

Summary of Key Findings ................................................................. 81

Research Question 1 ........................................................... 81

Research Question 2 ............................................................... 84

Research Question 3 ……........................................................ 85

Research Question 4 ............................................................. 86

5. SUMMARY, DISCUSSION, CONCLUSIONS, IMPLICATIONS, AND RECOMMENDATIONS ....................................................... 87

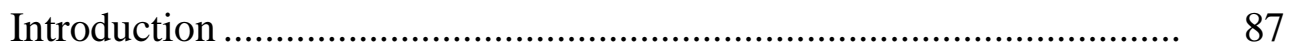

The Problem ………………………........................................ 87

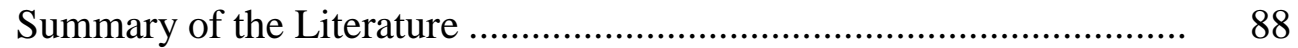

Trends in Curriculum Development............................................... 89

Implementation/Teaching Concerns …………………….............. 91

Testing and Evaluation Concerns.................................................. 91

Methodology ............................................................................ 92

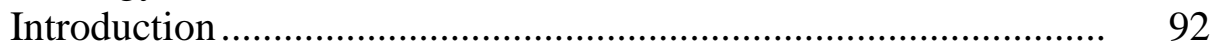




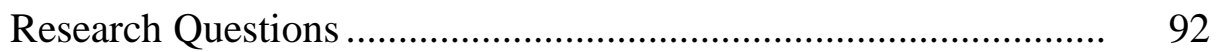

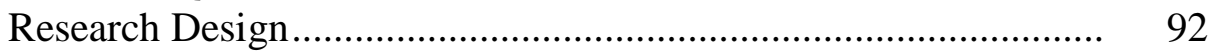

Population and Sample ....................................................... 93

Instrumentation ................................................................. 93

Reliability and Validity ......................................................... 93

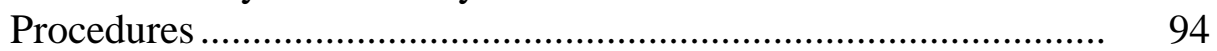

Data Analysis ....................................................................... 94

Summary of Key Findings ............................................................... 95

Discussion of Key Findings ............................................................. 96

Research Question 1 ............................................................... 96

Research Question 3 ............................................................... 101

Implications for Practice .................................................................. 105

Recommendation for Future Research .............................................. 109

Appendix

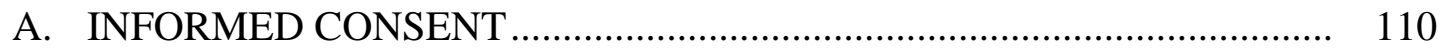

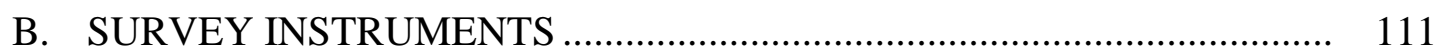

C. DANIELSON'S FRAMEWORK FOR TEACHING ………....................... 129

D. ANDREWS UNIVERSITY IRB APPROVAL ........................................... 130

E. NEW YORK CITY DEPARTMENT OF EDUCATION

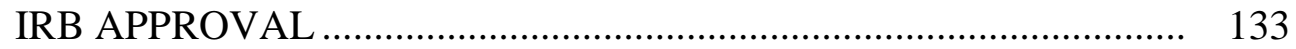

F. NIH CERTIFICATE OF COMPLETION OF TRAINING

ON PROTECTING HUMAN RESEARCH PARTICIPANTS ........................... 136

G. SOLICITATION FOR PARTICIPATION CARD ….................................... 137

H. SOLICITATION FOR PARTICIPATION IN

THE NYSUT NEWSPAPER ……………………....................... 138

I. SOLICITATION FOR PARTICIPATION IN

THE NEW YORK DAILY NEWS ................................................... 139

J. EMAIL SOLICITATION FOR PARTICIPATION ……………………....... 140

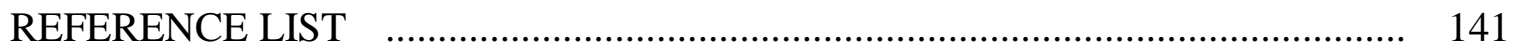

VITA 


\section{LIST OF FIGURES}

1. Typical Expression of Concern about the Innovation ........................................ 15

2. The Stages of Concern About an Innovation ................................................... 16

3. Common Core Instructional Shifts in ELA/Literacy ........................................... 26

4. Stages of Concern: Typical Expression of Concern About the Innovation........... 44

5. Frequency of Implementation Scales before Pilot Test........................................ 53

6. Frequency of Implementation Scales After Pilot Test ......................................... 53

\section{LIST OF TABLES}

1. Frequency of Implementation Scales ........................................................... 52

2. Demographic Characteristics: Gender, Ethnicity, and Level of Education .......... 58

3. Education-Related Characteristics of Participants ………................................... 60

4. Summary of Extent of Implementation of the Common Core State .................... 62

5. Level of teacher implementation of reading core standards ................................ 63

6. Level of teacher implementation of writing core standards .................................. 64

7. Level of teacher implementation of speaking/listening core standards ................. 66

8. Level of teacher implementation of language core standards .............................. 67

9. School Type Differences on Reading Core Standards ....................................... 68

10. School Type Differences on Writing Core Standards........................................... 69

11. School Type Differences on Speaking/Listening Core Standards......................... 70 
12. School Type Differences on Language Core Standards

13. Spearman rho correlation between core standards and years of teaching experience

14. Percent of teachers at different stages of concern

15. Unconcerned (Self): Little concern about or involvement with the CCSS Innovation

16. Informational (Self): A general awareness of the CCSS and interest in learning more details about it.

17. Personal (Self): Uncertainty about the demands of the CCSS, adequacy to meet them, and roles

18. Management (Task): Focuses on the processes and tasks using the CCSS and the best use of information and resources

19. Consequence (Impact): Focuses on the impact of CCSS on students in teacher's immediate sphere of influence

20. Collaboration (Impact): Focuses on coordinating and cooperating with others regarding use of the CCSS

21. Refocusing (Impact): Focuses on exploring ways to reap more universal benefits from the CCSS, making major changes to it or replacing it with a more powerful alternative

22. Spearman Rho Correlation between Implementation of Core Standards and Stage of Concern 


\section{CHAPTER 1}

\section{INTRODUCTION}

\section{Background of Study}

\section{Overview of Curriculum Innovation in America}

America has a long history of education reforms with a continuous shift in emphasis, currently in high-stakes testing and accountability. "As we enter the 21 st century, curricular controversy continues. National and state standards are a major issue in every school district; the debate on what is essential in English language arts arises in every state and national testing and a nation that looks at statistics for evidence of learning" (Maxwell \& Meiser, 2001, P. 37). According to Pinar (2008), "Attention to the history of the field is essential as it alerts scholars and schoolpersons [sic] that curriculum issues occur in historical time and in political context" (p. 11). Curriculum innovations mirror changes in national priorities. "During the 1980s and 1990s, efforts to improve teaching and learning processes moved away from discrete innovations and toward looking at the change in terms of organizations and systems" (George et al., 2013, p. 2). "This country," as Marshall et al. (2007) described it, "has become obsessed with the measurable academic progress of America's schoolchildren compared to those of other industrialized nations" (p.248).

The present Common Core State Standards reform initiative is no less controversial than those of the mid-1980s: A Nation at Risk in 1983, America 2000 in 
1987, and Goals 2000 in 2004 (Eisner, 2001, in Flinders \&Thornton, 2009, p. 327;

Sleeter \& Stillman, 2005, in Flinders \&Thornton, 2009, pp. 305-306; Darling-Hammond \& McCloskey, 2008, in Ornstein, Pajak \& Ornstein, 2011, p. 336, Schiro, 2013, pp. 3539, Schneider, 2015, pp. 1-19). By 1998, standards-based assessment became the dominant emphasis on education reform (Barlowe \& Cook, 2016, p. 6). As documented in the Hechinger Report, "There's a big push right now to improve U.S. high schools, with everyone from politicians to educators and foundations and corporations weighing in" (2016).

\section{Common Core State Standards}

Currently, the push is to get all American students to become capable of navigating, reflecting, and critically thinking about complex texts. According to curriculum scholars and education historians, the dissatisfaction with the performance of American schools when compared to other nations ushered in another wave of education reform, the Common Core Standards. As noted by Johnson (2002), "Evidence continues to build around the necessity for all students to engage and become proficient in rigorous curriculum content and problem-solving skills" (p. 10). However, the proposed curriculum initiatives are becoming more complicated and devastating than ever before, and the use of the data generated from the accompanying high stakes testing is equally of dismal consequences to students, teachers, administrators, and school districts. "Today, change incorporates much more comprehensive vision for school improvement. We have transitioned from clearly defined, easily delineated innovations to complex, multifaceted innovations and school improvement projects" (Hall et al., 2013, p.43). 
The Common Core State Standards were written in response to the push to get all American students to become reflective and critical thinkers capable of navigating complex texts, as noted earlier. The asserted goal of the Common Core Standards is to ensure that "all students, regardless of their circumstance, receive a content-rich education in the full range of the liberal arts and sciences, including English, mathematics, history, the arts, science, and foreign languages" (commoncore.org). New York State was one of the first states to adopt and implement the Common Core Standards as part of its Regents Reform Agenda to provide students for college and careers. The Board of Regents in its July 2010 meeting adopted the Common Core State Standards for English Language Arts \& Literacy and Mathematics and created the Common Core Learning Standards (CCLS) by and adding New York-specific components (EngageNY, 2013). In Spring 2014, New York State administered the first Regents Examination in English Language Arts (Common Core) to communicate to all educational stakeholders measures of student proficiency on the competencies students need for college and career success (EngageNY, 2014).

The good purpose and use of Common Core State Standards assessments are explicitly stated in both the New York City Department of Education and New York State Education Department websites. According to the New York City Department of Education,

Educators use student test results to assign students to appropriate classes and identify areas where the student needs extra help or more challenging material. Teachers and principals use the results from the ELA Test to make decisions about promotion and summer school. Educators also examine school-wide results to identify broad instructional areas that require improvement. (NYCDE) 
Also, the New York State Education Department's Office of State Assessments

(OSA) explains the importance of high-stakes State assessments noting that,

State exams are used to measure the extent to which individual students achieve the NYS learning standards in particular subjects and to determine whether schools, districts and the State meet the required progress targets specified in the NYS accountability system and in Every Student Succeeds Act (ESSA). (OSA, 2018)

According to the New York State Education Department (NYSED),

Fundamentally, ESSA is about creating a set of interlocking strategies to promote educational equity by providing support to districts and schools as they work to ensure that every student succeeds. New York State is committed to ensuring that all students succeed and thrive in school no matter who they are, where they live, where they come from or go to school. (nysed.org)

However, in New York and many other states in the nation, parents, teachers, teachers' unions, the private sector, and the State are at war over the Common Core State Standards and Common Core standardized testing. Year after year, in New York State, more and more students opt out of the high-stakes Common Core Assessment. According to (Lui 2014), "A revolt over excessive testing is heating up in New York." Barlowe and Cook (2016) have noted,

The large numbers of teachers and families of children in public schools participating in a movement to opt out of high-stakes, standardized testing indicate strong resistance to a school 'reform' that has done little to improve public education and much to undermine it." (p.4)

Furthermore, according to Disare (2017),

The Common Core standards have become a national lightning rod, with critics on the right saying they represent federal overreach (even though they were created by a consortium of states) and some educators insisting they made unrealistic demands of young students. Many states across the country have dropped the name Common Core and started their own revision processes.

In New York, the standards became closely linked with the high-stakes annual exams that students take. After one in five students boycotted those tests in 2015, Gov. Andrew Cuomo called for the standards to be revised. 
This scenario is not only challenging for educators but frustrating for students and their parents. Against this background, we can assume that educational reforms in America primarily aim at accountability, education funding, and career readiness. According to Ravitch (2010), Race to the Top funded data systems link test scores to individual teachers, thus rationalizing for using students' test scores to determine teachers' salaries (as cited in Pinar, 2012, p. 16). Ravitch (2010) suggests incorporating professional judgment and other measures of student achievement in any sound accountability system (as cited in Main 2012, p. 75).

\section{Statement of the Problem}

Curricular controversy has for long taken a center stage in America. Every education stakeholder defines curriculum in their terms and their expectation of educational outcomes differ accordingly. "They believe they know what should be taught in any given discipline, and equally important, just what a student should know or be able to do upon completion of that course study" (Maxwell \& Meiser, 2001, p. 36). The authors of the Common Core State Standards crafted them to ensure equitable educational opportunities for all students. All students, despite their situation, are expected to receive a comprehensive, high-quality education.

Unfortunately, the hasty adoption and implementation of the curriculum and the associated high-stakes testing are problematic for all education stakeholders. The punitive use of students' test scores in the evaluation of educators and school funding exacerbates the issues about the curriculum. Educators across America feel threatened because of the implications students' test scores and graduation rates have on the decisions regarding their 
retention or dismissal, school funding, and closing down of schools. "The Perception of a potential or real reduction in status can generate a strong threat response... a status threat can occur through ... simply suggesting someone is slightly ineffective at a task...." (Rock, 2008, pp. 3-4). The problem with the use of standardized test scores in this manner is the negative consequences it has on students, especially the poor. Zimmerman (2010) noted concerning the threat to close down underperforming schools under No Child Left Behind and Race to the Top initiatives, that government insistence on standardized testing as the sole educational achievement primarily victimizes poor students. When threatened with closure, schools "'tailor their curriculums as precisely as possible to the tests, even providing minute-by-minute scripts for the teachers'" (as cited in Pinar, 2012, p.17).

So, based on the evaluation measures built into Common Core State Standards, one can view it as more of an accountability tool than a curriculum. Munson (2011) noted that the Common Core Standards in and of themselves are not curriculum and will not mean much if implemented ineffectively (as cited in Main, 2012, p. 74). According to Dean Fixsen, founder of the National Implementation Research Network (NIRN), the effect of national educational reform efforts in the last 50 years on student outcomes has been zero. The reason being "ineffective implementation of effective practices and the effective implementation of ineffective practices" (as cited in Ecker, 2016, p. 1). This observation makes a case for taking a hard look at how any new curriculum initiative could upset the instructional Core - teachers, students, and content. Change in any form and place upsets the status quo.

Furthermore, as teachers continue to grapple with the implementation of the Common Core Standards, President Obama's administration in response to the nation- 
wide revolt against the curriculum signed into law Every Student Succeeds Act (ESSA)

in December of 2015 to which Weigarten (2016) remarked that,

The passage of the ESSA provides a much-needed opportunity to move past the era of high-stakes testing, and punitive sanctions, which left students stressed or bored, parents frustrated, and teachers demoralized. The ESSA is not perfect, but it maintains the original intent of the Elementary and Secondary Education Act by supporting the disadvantaged schools and children who need it most. (p. 1)

The passage of ESSA was supposed to resolve the issues surrounding the

Common Core. Still, according to Weingarten (2016), the day after the new law went into effect, more than 172,000 concerned educators and activists participated in a telephone town hall about the classroom effects of the new law (p. 1). This immediate reaction of educators indicated teachers were concerned about the fate of Common Core State Standards and its continuing implementation in the wake of the ESSA. Fullan (2001) noted that we have become so accustomed to the presence of change that we rarely stop to think what it means while experiencing it at a personal level. The crux of the innovation is how individuals come to grips with this reality (p. 29).

The conflicting view of the education stakeholders regarding the purpose of Common Core-related assessment data is problematic to educators and deserves to be studied. McMurrer and Frizzell (2013) evaluated efforts that were being made to implement the Common Core Standards, its adoption, and diffusion. They focused on the administration and implementation of the curriculum. Unfortunately, there were no studies to help in understanding teachers' concerns and the extent to which they were implementing the Common Core Standards. Given these problems, the following four research questions were used to achieve the purpose stated below. 


\section{Purpose of the Study}

New York State schools plan to transition from the Common Core State Standards (CCSS) to the Next Generation Standards. Successful implementation of any innovation can be challenging and, most times, complicated. In some cases, it involves a restructuring of the system is required. The purpose of this study was to examine teachers' concerns and the extent to which they were implementing the CCSS in English language arts in the State of New York.

\section{The Research Questions}

To following research questions were explored to understand the afore-stated problem.

1. The what extent do teachers in New York State implement the English Language Arts (ELA) Common Core State Standards?

2. Is the extent of implementation related to school level (middle vs. high school) and years of implementing common core standards?

3. What concerns do New York State ELA teachers have regarding the implementation of the Common Core State Standards (CCSS) and at what stages are their concerns?

4. What relationships exist between teachers' Stages of Concern and their extent of implementation of the ELA Common Core State Standards?

\section{Significance of the Study}

Standardized curriculum and testing have become a national obsession as well as a political talking point. According to City et al. (2009), “Americans are much more comfortable talking about changing the content and teaching than they are about 
changing the role of the student in instruction. We focus more attention on textbook adoptions and curriculum alignment... than we do on analyzing students' actual responses to the content, what motivates them to high levels of engagement with the content, and their actual role in the instruction process" (p. 26). According to Johnson (2002),

Assessing where your school or district is involves probing perceptions about why things are as they are. It means asking the hard questions: What are we doing? What is working? What is not working? Educators need to evaluate the services they offer students and how they are performed.

Questions should lead not to finger-pointing, but to identifying institutional policies and practices that affect student achievement. Determining where the school is requires individual and collective reflection. A climate of trust, risk taking, and openness must be fostered. (p. 127).

Learning, according to Black \& William (1998), is driven by the interaction of the teacher and the students in the classroom and the ability of the teachers to manage other complex factors and demanding situations efficiently. Therefore, ascertaining teachers' concerns and the extent to which they implement the curriculum is critically important in establishing trust, risk-taking, and openness in the school to ensure that effective teaching and learning are taking place. According to Dean Fixsen (n.d.),

We have the research and know what works. We also know the evidence-based practices (EBPs) - what to do. The gap is the to - we're not getting to implementation. In fact, we are not facing an implementation gap but a chasm with sharp peaks and overwhelming depths. Until we apply the same intentionality to implementation that we assign conducting research and identifying practice... we will continue to experience the same outcomes. Failure to address implementation as we work to improve student outcomes is tantamount to hoping Evel Knievel would land his motorcycle on the other side of the canyon, and instead watch him fall back off the ledge. We must no longer hurl research about practices across the canyons but strategically build the structure to support the implementation of those practices and improve student outcomes. (as cited in Ecker, 2016, pp. 1 \& 3) 
Also, we know that generally, the problem of implementation of educational reform is enormous and requires understanding teachers' concerns and the extent to which the application is taking place. "The nature of the individual teacher has a significant impact on their eventual implementation of an innovation (Evans \& Hopkins, 1988; Hopkins, 1990, cited in Hall, et al., 2013, p. 35). According to Maxwell and Meiser (2001) "Faced with curricular controversy, which appears to be a normal corollary in a democratic society, teachers need a strong, valid response (, 2001, P. 37).

It is worth noting that the revised standard, Next Generation, is not very different from the Common Core State Standards it is meant to replace. According to Disare (2017),

The new standards — which spell out the knowledge and skills students should acquire at each grade level - try to ensure students are learning the right skills at the appropriate grade level and clarify vague or confusing wording in the previous standards.

For instance, in an earlier draft of the revised standards, the state swapped the words "grade-level" text in a third-grade reading standard with "a variety of texts," presumably to meet the needs of students who can't yet read material written for students their age.

Therefore, this study's findings would benefit teachers and administrators as they embark on adopting and implementing the Next Generation, a presumably upgraded Common Core State Standards. First, the findings would help education administrators and policymakers in making effective adoption and implementation, and evaluation policies regarding any new curriculum. Second, district and school building administrators could use them to inform their policies, instructional planning, teacher collaboration, implementation monitoring and evaluation, and professional development for teachers and themselves. Third, teachers could use them to inform their instructional planning delivery, delivery, and assessment. Ballard \& Bates (2008) noted that 
"Regardless of the types of evaluation tools a school district implements for teachers, it is the responsibility of teachers themselves to be informed of educational practices and research that affects the instruction delivered to students" (p. 562).

\section{Theoretical and Conceptual Frameworks}

The theoretical frameworks for this study are the Innovation-Decision Process and the Concerns-Based Adoption Model (CBAM).

\section{The Innovation-Decision Process}

The theory of innovation-decision process asserts that an individual or a system's evaluation of a new idea and the decision to incorporate or not to incorporate it involves a process through which a series of choices and actions take place over time (Rogers, 2003, p. 168). The rate of adoption is "the relative speed with which an innovation is adopted by members of a social system" (Rogers, 2003, p. 23), such as the school system. The rate of adoption of innovation varies in different social systems, and many aspects of diffusion cannot be accounted for by individual behavior. The system's norms and its other characteristics have both direct and indirect impacts on the behavior of its members (Rogers, 2003, p. 23).

\section{Concerns-Based Adoption Model (CBAM)}

The CBAM provides ways for studying teacher change in the context of educational innovation (Wang, 2014, p. 23). The decisions to adopt or to resist the adoption of any innovation (such as the Common Core State Standards) occur in a social context that involves policymakers, administrators, teachers, students, and parents- $\mathrm{a}$ complex social structure. The social context of the adoption of the Common Core State 
Standards (CCSS) is replete with concerns related to its rigor, implementation, assessment, and use of the assessment scores. Katz (1961) opined that "it is unthinkable to study diffusion without some knowledge of the social structures in which potential adopters are located as it is to study blood circulation without adequate knowledge of theveins and arteries" (as cited in Rogers, 2003, p. 25).

Accordingly, the Concern- Based Adoption Model (CBAM) was used in this study to determine the socio-emotional structures that underlie teachers' concerns with regards to implementing the Common Core State Standards.

The CBAM framework assumes that there is a stage-defined progression of feelings, perceptions, reactions, and attitudes of individuals within a system toward innovations and that there are differences in the levels of use of innovation among individuals in the same system. "Reform," noted Johnson (2002), "ultimately personal and requires behavioral modification. Reflective questions that provoke professionals to assess their underlying assumptions in preparation for deep-level reforms are essential" (p. 127). The CBAM framework was appropriate for this study because it helped to understand at granular stages the complexity of teachers' concerns and the trajectory of their learning and development as they continue to grapple with the implementation of the Common Core Standards amidst the accountability intimidations. It provides ways for studying teacher change in the context of educational innovation (Wang, 2014, p. 23).

According to SEDL, nonprofit education research, development, and dissemination organization, a team of researchers at the Research and Development Center for Teacher Education at the University of Texas at Austin developed the Stages of Concern in the 1970s and 1980s as a component of the Concern-Based Adoption 
Model (CBAM). They have since tested it for reliability and validity. They updated it for reliability in 2006. Today, CBAM, SEDL, further noted, continues to be applied in a variety of educational, organizational, and research settings primarily to help leaders, evaluators, and researchers understand, monitor, and guide the complex process of implementing new and innovative practices.

The first rationale for using CBAM is that employees bring their aspirations and visions for the future, their interests, values, preferences, beliefs, and sets of commitments from outside to the workplace which impact the way they respond to both job and career (Morgan, 1998, p. 154). According to Holloway (2003), "Just as there are research-based educational innovations, there is a research-based program for aiding innovation - the Concern-Based Adoption Model or CBAM. It offers a way to understand and address educators' common concerns about change” (p. 1).

The second rationale for using CBAM is that other researchers have used it in many types of educational innovations. Newman (2011) discussed how several researchers used CBAM in studying the implementation of computers in schools. In this study, the researchers found CBAM potent in explaining the actions of teachers. Khobili and O'toole (2012) also discussed a particular example of how a small group of teachers in Lesotho, who through the lens provision of CBAM, engaged in action research to investigate their understanding and practice in a scenario of externally imposed innovation. Also, Hollingshead (2009), in a study of a district-wide implementation of a character education program in Rockwall Texas, used the CBAM framework (as cited in Wang, 2014, p. 24). 


\section{Stages of Concern (SoC)}

The Stages of Change (SoC) has to do with the progression of peoples' feelings, perceptions, reactions, and attitudes in a change process (Hall and Hord, 2011, pp. 68, 93). The Concern-Based Adoption Model (CBAM) provides ways for studying teacher change in the context of educational innovation (Wang, 2014, p. 23). The SoC elemental expressions are illustrated in Figure 1 below. The $\mathrm{SoC}$ framework is presented in Figure 2.

The use of the innovation-decision making process as an underpinning theory is appropriate for this study. It is fitting because its process components can be subsumed in the Concerns-Based Adoption Model (CBAM). CBAM tools-Stages of Concern Questionnaire (SoCQ) and Levels of Use Interview Protocol (LoUIP) have been found appropriate for identifying and labeling innovation adopters' stages of concern and levels of use or implementation of an innovation. Both tools ask questions that practically pertain to the various elements of the innovation-decision making process and implementation of innovation. In this study, to get a broader perspective than possible with the Levels of Use Interview, a self-developed, pilot-tested survey instrument was used instead of the Levels of Use Interview Protocol to ascertain the extent to which teachers are implementing the Common Core State Standards. This approach to the study is critically important because "The structure of a social system can facilitate or impede the diffusion of innovations" (Rogers, 2003, p. 25).

\section{Definition of terms}

1. Common Core Standards. A brief description of the Common Core or Common Core State Standards 


\begin{tabular}{|c|c|c|}
\hline & Stages of Concern (SoC) & Expression of Concern \\
\hline 6 & Refocusing & $\begin{array}{l}\text { - I have some ideas about something that } \\
\text { would work even better. }\end{array}$ \\
\hline 5 & Collaboration & $\begin{array}{l}\text { - I am concerned about relating what I am } \\
\text { doing with what my co- workers are doing. }\end{array}$ \\
\hline 4 & Consequence & $\begin{array}{l}\text { How is my use affecting my clients } \\
\text { (students)? }\end{array}$ \\
\hline 3 & Management & $\begin{array}{l}\text { - I seem to be spending all my time getting } \\
\text { materials ready. }\end{array}$ \\
\hline 2 & Personal & - How will using it affect me? \\
\hline 1 . & Informational & - I would like to know more about it. \\
\hline 0 & Unconcerned & - How will using it affect me? \\
\hline
\end{tabular}

Figure 1. Typical expression of concern about the innovation. Adapted from Hall \& Hord, 2011, p. 72.

2. Curriculum. The arrangement of subjects, a structure of prescribed knowledge (Maxine Green, 1971, in Flinders \& Thornton, 2009, p. 155).

3. Stages of Concern (SoC). The progression of peoples' feelings, perceptions, reactions, and attitudes in a change process (Hall and Hord, 2011, pp. 68, 93)

4. Implementation. Teaching of lessons that inculcate in students the skills delineated in the Common Core State Standards.

5. ESSA. Every Student Succeeds Act is a federal legislation that requires that all students be given opportunity they need to experience academic success (nysed.org).

6. The Concerns-Based Adoption Model (CBAM). A conceptual framework for studying teacher change in the context of educational innovation (Wang, 2014, p. 23). 


\begin{tabular}{|c|c|c|c|}
\hline \multirow{3}{*}{$\sum^{e}$} & 6 & Refocusing & $\begin{array}{l}\text { The individual focuses on exploring ways to reap more } \\
\text { universal benefits from the innovation, including the possibility } \\
\text { of making major changes to it or replacing it with a more } \\
\text { powerful alternative. }\end{array}$ \\
\hline & 5 & Collaboration & $\begin{array}{l}\text { The individual focuses on coordinating and cooperating with } \\
\text { others regarding use of the innovation. }\end{array}$ \\
\hline & 4 & Consequence & $\begin{array}{l}\text { The individual focuses on the innovation's impact on students } \\
\text { in his or her immediate sphere of influence. Considerations } \\
\text { include relevance of the innovation for students; the evaluation } \\
\text { of student outcomes, including performance and competencies; } \\
\text { and the changes needed to improve student outcomes. }\end{array}$ \\
\hline$\frac{u}{6}$ & 3 & Management & $\begin{array}{l}\text { The individual focuses on the processes and tasks of using the } \\
\text { innovation and the best use of information and resources. } \\
\text { Issues related to efficiency, organizing, managing, and } \\
\text { scheduling dominate. }\end{array}$ \\
\hline \multirow{3}{*}{$\frac{5}{5}$} & 2 & Personal & $\begin{array}{l}\text { The individual is uncertain about the demands of the } \\
\text { innovation, his or her adequacy to meet those demands, and/or } \\
\text { his or her role with the innovation. The individual is analyzing } \\
\text { his or her relationship to the reward structure of the } \\
\text { organization, determining his or her part in decision making, } \\
\text { and considering potential conflicts with existing structures or } \\
\text { personal commitment. Concerns also might involve the } \\
\text { financial or status implications of the program for the } \\
\text { individual and his or her colleagues. }\end{array}$ \\
\hline & 1 & Informational & $\begin{array}{l}\text { The individual indicates a general awareness of the innovation } \\
\text { and interest in learning more details about it. The individual } \\
\text { does not seem to be worried about himself or herself in relation } \\
\text { to the innovation. Any interest is in impersonal, substantive, } \\
\text { aspects of the innovation, such as its general characteristics, } \\
\text { effects, and requirements for use. }\end{array}$ \\
\hline & $\overline{\mathbf{0}}$ & Unconcerned & $\begin{array}{l}\text { The individual indicates little concern about or involvement } \\
\text { with the innovation. }\end{array}$ \\
\hline
\end{tabular}

Figure 2. The Stages of Concern about an innovation. Source: George, A. A., Hall, G. E., Stiegelbauer, S. M., 2006, p. 8. 


\section{Delimitations of the Study}

First, the inclusion and exclusion criteria limited participation in this study to Grades 6-12 English Language Arts teachers. Only tenured and non-tenured, who had implemented the Common Core State Standards, one or more years participated.

Second, although the Stages of Concern Questionnaire (SoCQ) is proven to be reliable when properly used, the producers strongly recommend strictly limiting its use for diagnostic purposes for personnel directly involved in the process of an innovation adoption or production (George et al., 2013, p. 55). As a result, to ensure the validity of the data for this study, only public school teachers participated. Private school teachers did not participate; they are not subject to the same performance evaluation consequences as public school teachers, and their concerns and extent of implementation may not be relevant to this study. The purpose of the use of exclusion criteria was to identify those factors that could interfere with the interpretation of the findings and potentially confound the results (Portney \& Watkins, 2000, p. 140).

Third, in some cases, sub-questions help to further specify the central question into some areas for inquiry (Creswell, 2013, p. 140). The demographic data generated from the sub-questions can help in determining why the intensity of particular concerns varies at certain stages (George et al., 2013, p. 31). Although the demographic page attached to the SoC Questionnaire provides demographic data such as age, gender, years of teaching experience, and cycles of experience with the innovation, there have not been remarkable relationships demonstrated between standard demographic variables and Stages of Concern data. The state of the user, as hypothesized in the Concerns-Based Adoption Model, significantly trumps the importance of the usual demographic variables 
in the determination of a user's response to an innovation (George et al., p. 52). So, I included in this study analyses of the demographic data collected to shed more light on the significant findings. This study's findings represent a preliminary road map to broader studies on teachers' Stages of Concern and extent of implementation of the Common Core States Standards among English Language Arts teachers.

\section{Limitations of the Study}

This study's limitations include potential misuse of the Stages of Concern Questionnaire and sample size. The use of survey instruments in the quantitative component of the research has a few weaknesses that limit data collection in some ways, such as response rate and completeness of responses. Thus, the findings and conclusions are limited to the number of thoroughly completed responses. Furthermore, the literature review for current applications of the Stages of Concern is complicated, and the discussion of the SoC is often done in combination with that of the Levels of Use (LoU) or Innovation Configurations (another Concern-Based Adoption Model's diagnostic component). Different people use the $\mathrm{SoC}$ in different ways for various purposes, with some adaptations of the SoCQ that compromise its reliability and original intent (George, et al., 2013, p. 57).

\section{Organization of the Dissertation}

In Chapter 2, I reviewed the literature on the topic of this study that pertains to the inclusion and exclusion criteria, the historical framework of reference, concerns related to Common Core State Standards (CCSS) and implementation concerns, and recommendations for implementing the Common Core State Standards. In Chapter 3, I 
discussed the procedures and methodology used in the study: The research design, population and sample, instrumentation, reliability, validity, procedures, and data analysis. In Chapter 4, the reported the statistical analysis of the data collected and rendered outputs rendered in tables and briefly explained them. Last, in Chapter 5, I summarized the study findings, including explanations of conclusions reached from the analyses and evaluation of the data. I finally discussed the implications of the results and proffer recommendations for practice and further study. 


\section{CHAPTER 2}

\section{LITERATURE REVIEW}

\section{The Search: Inclusion and Exclusion Criteria}

Bearing in mind the topic that Common Core State Standards was a recent curriculum reform initiative with fewer researches done on the nature of issues of its implementation challenges, I conducted a literature review on various electronic databases. I combed through EBSCO, ProQuest, and ERIC. The Andrews University and Lehman College libraries provided access to these electronic databases. To focus this literature review on standards-based curriculum issues, implementation challenges, and testing, I searched specific keywords and phrases to ensure that only articles related to the topic of the search are retrieved and included in the review. I searched keywords such as curriculum reforms in the United States, Common Core State Standards, Common Core Learning Standards, common core standards, and standards-based curriculum, testing, and standardized tests in the electronic databases and web browsers. I read every retrieved article or study to determine its relevance to the topic of this proposed study. I included only those articles or studies that are relevant to my research topic in the review. The same criterion applied to the books searched. 


\section{Historical Framework of Reference}

Schiro (2013) provides a concise history of Curriculum reform in the United States, dating back to the 1800s. Charles W. Eliot (1834-1926) was the president of Harvard University, a scholar academic and proponent of academic education. He believed that through the development of their mental power - their thinking and reasoning power through the study of their cultural heritage, the intellectual development of people could be achieved. William Torrey Harris (1835-1909), an elementary school teacher, believed that the essence of schooling was to elevate children above their savage nature and to prepare them for a civilized life for participation in the American democracy. Both Eliot and Harris were notable figures in the curriculum movements of the 1800s. The National Education Association's (NEA) first panel on education created in 1892 - the Committee of Ten, with Eliot as the chairman. Eliot and Harris were prominent members of the Committee, and the Committee's report in 1893 reflected their beliefs - the standardization of the high school academic curriculum: 4 years of English, history, mathematics, and foreign language and 3 years of science, and since then that recommendation had come to stay. The committee's recommendation provided for equal access to an excellent education to all children (p. 35-38, see also Pinar, 2021, pp. 15-42). The present day's Every Student Succeeds Act, ESSA) is nothing more than a recast of the committee's recommendation.

The Scholar Academic ideology goals were reflected in the crafting of the 20thcentury reports such as A NATION AT RISK IN 2004, TEACHING AT RISK IN 2004, the Goals 2000: Educate America Act in 2004, and the No Child Left Behind Act (NCLB) in 2002 (Schiro, 2013, pp. 38-39, see also Pinar, 2021, pp. 15-42). 
Between the mid-1960s to the mid-1980s, another wave of fear ran through the American public. Other ideologues overtook the Scholar Academic initiatives as the National Assessment of Education Progress (NAEP) report showed declines in student achievement in academic subjects when compared to those of other nations around the world. The National Commission on Excellence in Education (NCEE) published A NATION AT RISK to illuminate the threat facing the United States. The recommendations in the report were almost identical to those in the Elliot and Harris' Committee of Ten made 90 years past. With the publication of A NATION at Risk, new curriculum initiatives emerged, many of which promoted Academic Scholar agendas (Schiro, 2013 pp.39-40, see also Pinar, 2021, pp. 15-42).

History as we know, repeats itself. In recent times, the demand for curriculum reform has become a global zeitgeist. Like in other nations, the debate and fight over curriculum reform are continuing to rage in America. It is multi-faceted and often involves different stakeholders. Longstreet (1993) noted that "Every few years, a major movement of some kind appears" (as cited in Marshall et al., 2007, p. 269). Raising the standards of learning through schooling has become an important national priority that has caught the attention of many nations in recent years, causing governments, the world over, to vigorously pursue this goal (Black \& William, 1998).

As a result, the search for the concerns and implementation challenges related to the Common Core State Standards and standardized testing was broad-based. Studies and articles on standard-based curriculum and instruction provided an understanding of the general curriculum issues and implementation challenges that fundamentally apply to the Common Core State Standards reform. Bounded within this study's historical framework 
of reference are trends in curriculum development in the United States concerning the Common Core State Standards, implementation and teaching concerns, and testing and evaluation concerns, students' academic success concerns, accountability concerns, and professional development concerns.

\section{Trends in Curriculum Development}

The Common Core State Standards is one of the many curriculum innovations in the history of American education and is not immune to the harsh scrutiny that those before it suffered. As the pressure on education from the outside intensifies, Randi Weingarten, President of the American Federation of Teachers (AFT), has noted that "Public education has been subjected to countless reforms that were undermined by hasty, inadequate implementation" (2016, p. 1). On the same note, Wraga (1999) opined that "Politicians have encoded national education goals and subobjectives [sic] into federal law and have touted the 'voluntary' adoption of national standards and assessments by state and local education agencies" (p.4). Across the nation, states have developed curriculum standards that delineate what students should learn, and this has equally led to the raising of standards for student learning. The curriculum has focused on what schools should do, fundamental values and beliefs about how the youngsters should perceive the society, and the expectations of adults as they enter the world (Sleeter \& Stillman, 2005, in Flinders \&Thornton, 2009, p. 303).

Two curriculum standards movement and alignment arguments appeal to parents, policymakers, and politicians, according to Fenwick English (1992, as cited in Wraga, 1999): equity and accountability arguments. The equity argument maintains that majority-culture students are favored by the socio-economic bias in standardized tests 
and work in tandem against minority-culture students and limit their educational opportunities and life chances. The accountability argument, English asserted, projects curriculum alignment as a useful teacher-management tool (p. 6). Likewise, Eisner (2001) argued that the formulation of standards of measurement of performance had always aimed at making teachers and school administrators accountable to the stakeholders and for the public to know which schools are performing and which ones are not (in Flinders \& Thornton 2009, p. 327).

The spate of curriculum reforms in America has a constitutional origin. America is one of the few nations where the national ministry of education is not responsible for schools. Under the 10th Amendment to the U.S. Constitution requires that states are responsible for any responsibilities inexplicitly assigned to the federal government, and education is one of those responsibilities not mentioned in the Constitution. Consequently, every state's department of education has the burden of formulating its education standards, which accounts for the differences in what constitutes the curriculum standards of each state, resulting in the educational issues in the country (Eisner, 2001, in Flinders \& Thornton, 2009, p. 327).

\title{
The Common Core State Standards (CCSS)
}

\author{
Instructional Shifts Demanded \\ in Common Core State Standards
}

The Common Core State Standards is a core curriculum that seeks to ensure that all students, regardless of their circumstance, receive a content-rich education in the full range of the liberal arts and sciences, including English, mathematics, history, the arts, 
science, and foreign languages. The Common Core State Standards framework comprises six instructional shifts (see Figure 3), namely, balancing informational and literary texts for Pre-K-5, and for grades 6-12, knowledge in the disciplines, staircase of complexity, text-based answers, writing from sources, and academic vocabulary (EngageNY, 2012 ).

The Rationale for Common Core State Standards

As noted in the problem statement, the purpose of the Common Core standards is to ensure that all students, irrespective of their situation, receive a comprehensive, highquality education (commoncore.org, homepage). However, school improvement initiatives give rise to some issues. Eisner (2001) identified six issues that emanate from the features of rationalization as a concept for school improvement (in Flinders \& Thornton, 2009, pp. 327-335).

First, rationalization is dependent on the precise specification of the intended outcome, which is the intention for standards and rubrics. The argument is that standards and rubrics are necessary if we are to function rationally. So, our school reform efforts are rationalized primarily in the specification of intended outcomes and holding people accountable for results. Second, rationalization uses measurement (such as standardizedtests) as a means for assessing the quality of product and performance quality. Third, the basis for the rationalization of practice is the ability to control and make a prediction (using test scores). Fourth, rationalization does not emphasize interactions, and it does not take into account the totality of the conditions that interact in education and impact achievement. Fifth, rationalization promotes comparison, and comparison entails commensurability (which is lacking in education systems). Sixth, rationalization motivates action with extrinsic incentives, and the use of voucher system likens schools 


\begin{tabular}{l|l|l}
\hline Shift 1 & $\begin{array}{l}\text { Balancing } \\
\text { Informational } \\
\text { \& Literary Text }\end{array}$ & $\begin{array}{l}\text { Students read a true balance of informational and literary } \\
\text { texts. }\end{array}$ \\
\hline Shift 2 & $\begin{array}{l}\text { Knowledge in } \\
\text { the Disciplines }\end{array}$ & $\begin{array}{l}\text { Students build knowledge about the world (domains/ content } \\
\text { areas) through TEXT rather than the teacher or activities }\end{array}$ \\
\hline Shift 3 & $\begin{array}{l}\text { Staircase of } \\
\text { Complexity }\end{array}$ & $\begin{array}{l}\text { Students read the central, grade appropriate text around which } \\
\text { instruction is centered. Teachers are patient, create more time } \\
\text { and space and support in the curriculum for close reading. }\end{array}$ \\
\hline Shift 4 & $\begin{array}{l}\text { Text-based } \\
\text { Answers }\end{array}$ & $\begin{array}{l}\text { Students engage in rich and rigorous evidence based } \\
\text { conversations about text. }\end{array}$ \\
\hline Shift 5 & $\begin{array}{l}\text { Writing from } \\
\text { Sources }\end{array}$ & $\begin{array}{l}\text { Writing emphasizes use of evidence from sources to inform or } \\
\text { make an argument. }\end{array}$ \\
\hline Shift 6 & $\begin{array}{l}\text { Academic } \\
\text { Vocabulary }\end{array}$ & $\begin{array}{l}\text { Students constantly build the transferable vocabulary they } \\
\text { need to access grade level complex texts. This can be done } \\
\text { effectively by spiraling like content in increasingly complex } \\
\text { texts. }\end{array}$ \\
\hline
\end{tabular}

Figure 3. Common Core Instructional Shifts in ELA/Literacy. Adapted from EngageNY.org (2012)

to businesses that go out of business if they don't produce useful results (test scores) (pp. 327-328; see also Mohammed \& Fleck, 2010).

\section{Concerns Related to Common Core State Standards}

A common core curriculum that demands content and performance standards would be a significant departure from the existing policy and practice that provide differentiated curricula commensurate with the diversity of students' abilities and interests (McPartland, \& Schneider, p. 66). Much of the policy-making decisions 
regarding education in the United States, both before the No Child Left Behind Act (NCLB) and presently, aim at accomplishing two conflicting goals. That is, incorporating significant aspects of a widely acknowledged way of regulating curriculum content through a top-down approach while simultaneously maintaining the long-standing American tradition that allows control of education to local authorities (as opposed to national or state-level decision-makers). The No Child Left Behind legislation, unfortunately, failed to work as intended (Lin et al., 2002, in Schmidt \& Prawat 2006, p. 653). Khon (2010) noted that a national standardized test would accompany the core standards (in Main, L. F., 2012, p.75).

Weingarten (2016), the day after President Obama signed the Every Student Succeeds Act (ESSA), wondering how the new law could affect the classroom opined that it is common knowledge among educators that by creating a test-and-punish environment in America's schools, No Child Left Behind and Race to the Top policies despite the good motives behind them went wrong (p. 1). No wonder Pinar (2012) opined that "Standardization makes everyone stupid" (p. 55).

\section{Implementation/Teaching Concerns}

Learning is driven by what happens in the classroom between the teacher and the students. If teachers effectively manage other complex factors and demanding situations that exist in the classroom, standards can be raised (Black \& Wiliam, 1998). Knowing students' progress and difficulties would help teachers adapt their work to meet students' needs. They can know students' progress and problems through observations, class discussions, and reading students' work (Black \& Wiliam, 1998; see also Troia \& Olinghouse, 2013). 
Teachers in New York State teach a diverse population of students and under inequitable conditions that can positively and negatively impact their implementation of the Common Core State Standards or any new curriculum. The use of students' test scores to evaluate teachers and schools could provoke a status reduction threat to teachers and school administrators, and this could adversely impact their extent of implementation of any curriculum and the administration of the schools, respectively. "The Perception of a potential or real reduction in status can generate a strong threat response... a status threat can occur through ... simply suggesting someone is slightly ineffective at a task..." (Rock, 2008, pp. 3-4).

Sawchuk (2012) opined that "By any accounting, the challenge of getting the nation's 3.2 million K-12 public school teachers to integrate the expected changes into their practice is enormous" (p. 4). Teachers may be willing to implement the curriculum but may not have an adequate structure to facilitate the adoption of the innovation. "The structure of a social system can facilitate or impede the diffusion of innovations" (Rogers, 2003, p. 25). Teachers, by compulsion and with little or no attention to their concerns, already are implementing the standards at the same time they are trying to understand it. Pitching the standards at a level that may require teachers to function at a higher cognitive plane has become a matter of concern (Sawchuk, 2012, p. 4). Wallender (2014) predicted that the Common Core State Standards reform initiative would require several changes in philosophy, curriculum, instruction, and assessment (Wallender, 2014). This prediction may become real in the light of the fact that "Making a difference in the lives of students requires care, commitment, and passion as well as the intellectual know-how 
to do something about it" (Fullan 30), which seems to not to be the case with the Common Core.

\section{Testing and Evaluation Concerns}

Although No Child Left Behind legislation passed in 2001 aimed and reinforced achievement with test-based accountability as a means of raising achievement, yet the nation has fallen further behind on international assessments of student learning (DarlingHammond \& McCloskey, 2008, as cited in Ornstein, Pajak, \& Ornstein, 2011, p. 337). Under the standards-based accountability system, subjects outside the core (those that are not tested) are likely to be undermined (Siskin, 2003, in Flinders \& Thornton, 2009, pp. 318-319). "U. S. teachers have suffered mightily throughout the nation's new policies, and they resent it" (Hargreaves \& Shirley, 2008, in Ornstein, Pajak, \& Ornstein, 2011, p. 319).

Over-emphasis in student and teacher accountability has become an obsession.

Students are rigorously tested, and their test scores are used to evaluate their teachers and schools. "The public education," noted Johnson, "is currently in an era of accountability, high-stakes standardized testing, and standards-based reform" (Johnson, 2002, p. 4; See also Anderson \& Krathwohl, 2001, p. 250). The focus of accountability efforts in the United States is on the achievement of higher test scores. However, the kind of teaching and learning systems and practices capable of developing a widespread capacity for significantly greater learning was lacking (Darling-Hammond \& McCloskey, 2008, as cited in Ornstein, Pajak, \& Ornstein, 2011, p. 344).

Furthermore, according to Longstreet (1993) of the University of New Orleans, the federal government's pursuit of subject-oriented national assessments as a sole 
remedy or reform for education is a drawback to the early years of twentieth-century modernism. It delimits students' intellectual experiences in a pluralizing society (as cited in Marshall, et al., 2007, p.272; see also Snow-Gerono, p. 275). Pinar (2012), on the same token noted that, "By linking the curriculum to student performance on standardized examinations, politicians have, in effect, taken control of what is to be taught: the curriculum. Examination-driven curricula demote teachers to technicians in service of the state...." (p. 2).

\section{Students' Academic Success Concerns}

High-stakes testing has dramatically impacted the teaching and learning process. It has affected not only the curricula that teachers teach their students but also the way they teach them and how they and their students are evaluated. As Barlowe \& Cook (2016) noted, "High-stakes, test-driven assessment inhibits collaboration among educators, hinders student engagement, and undermines critical thinking" (p. 6). Anderson \& Krathwohl (2001) have also said that "increasingly teachers are confronted with state curriculum standards and corresponding state testing programs.... Generally, these assessments are referred to as 'high-stakes' assessments because critical decisions about students, teachers, and schools are made based on their results"(p. 248). The importance attached to these tests, they further noted, has risen correspondingly and has dire consequences both for the teacher, students, and administrators. `Students may be retained at a particular grade level for two or three years or denied a high school diploma altogether. Schools may be publicly labeled 'low performing' or in South Carolina, for example, 'critically impaired,' and the state Board of Education may take them over (Anderson \& Krathwohl, 2001, p. 249) 
Hargreaves and Shirley (2008) have remarked that the over-prized high-stakes standardized assessments which measure short-term academic gains have weakened the U.S. educational systems and turned them into "Enrons of educational change" (in Ornstein, Pajak, \& Ornstein, 2011, p. 319). Therefore, the development of teaching and learning systems and practices are critically important in any educational system that emphasizes high-stakes standardized testing. As a result, "compliance with the standards is enforced mainly through testing and textbooks" (Sleeter \& Stillman, 2005, in Flinders \& Thornton, 2009, p. 312).

Some scholars argue against standardized tests and standardized scores because it robs subjectivity and intellectual qualities out of education. One claim is that standardized test scores are meaningless, and standardized tests "foreclose originality, creativity, and independence of mind" (Grummet, 1988, as cited in Pinar, 2012, p. 30). Pinar (2012) argues that "Installing the instrumentalization of teaching as preparation to standardized tests vitiates academic study by stripping it of both subjectivity and the world, leaving us with neither intellect nor soul" (p. 33). Pinar (2012) further argues that "Without the agency of subjectivity, education evaporates, replaced by the conformity compelled by scripted curricula and standardized tests" (p. 43).

Another dimension of the problem is that the Common Core standardized tests are enforced simultaneously with the Common Core State Standards (CCSS). However, "Simply having a standard in place is no assurance that higher education and K-12 teaching are aligned to the standard and the expectations for college-level work" (Phillips \& Vandal, 2011). The Common Core State Standards for Writing and Language (CCSSWL), for example, there is no guidance provided for the teaching of grammar skills in 
writing in the Common Core State Standards for Writing and Language (CCSS-WL). Yet, struggling writers are not exempt from meeting higher writing standards (Troia \& Olinghouse, 2013).

Therefore, ascertaining teachers' stages of concern regarding the Common Core State Standards and their extent of implementing it is very vital for students' academic success. Main (2012) asserts that, "While the standards have promise, there is much work to be done as a nation before we are ready to implement them, especially with our youngest students" (p. 73). Change in educational practice occurs at the classroom level with the teachers and what they are doing with their students. As such the implementation of educational change involves a change in what teachers do (Fullan, 2001, p. 38).

\section{Accountability Concerns}

According to Daniel T. Willington, a professor of psychology at the University of Virginia, in Charlottesville, more challenging standards for students translate to more challenging content for teachers and also impacts the support teachers needed to receive (as cited in Sawchuk, 2012, p. 4). Wraga (199) also noted, "The heightened value placed on high-stakes testing by politicians and policymakers has compelled many educational leaders to search for legitimate and promising methods to raise student achievement levels" (p. 4). Such measures could include teaching to the test at the expense of teaching critical thinking skills in students.

Standards and accountability measures on their own are no guarantee for a successful implementation of the classroom; they are just part of the whole instructional core. The elements of instructional core- teacher, student and content (curriculum) do not function in isolation. What upsets one upsets the rest. "Intervening on any single axis 
of the instructional core means that you have to intervene on the other two to have a predictable effect on student learning" (City, E., et al., 2009, P. 26). According to Heifetz and Linsky (2004), "Policymakers are demanding performance accountability measures for students and educators that bring into question deeply held notions of good teaching, good learning, and success in the classroom....” (p. 37). Similarly, Stigler and Hiebert (n.d., as cited in Black \& Wiliam, 1998), have noted that estimating standards and accountability over teaching and learning processes do not translate to teacher improvement (p. 81).

Also, we must bear in mind that accountability measures can be threatening and negatively impact performance. "Performance reviews often generate status threats, explaining why they are often ineffective at stimulating behavior change....When threatened, people may defend a position that doesn't make sense, to avoid the perceived pain of a drop in status" (Rock, 2008, p. 4). Linking learning to test scores does not serve a useful purpose. It encourages the drop out of students who are weak in the core subjects and lack the motivation to learn them, and the expulsion of students whose failing scores could cause the schools to lose the bonuses that increased test scores attract (Ravitch, 2010, as cited in Pinar 2012, p. 18).

Therefore, as New York State transitions into a newer curriculum, the Next Generation, ascertaining the teachers' stages of concern regarding predecessor curriculum, the Common Core State Standards, and the extent of its implementation in the wake of Every Student Succeeds Act (ESSA) becomes necessary. "No matter how honorable the motives," noted Fullan (2001), "each and every individual who is necessary for effective implementation will experience some concerns about the meaning 
of new practices, goals, beliefs, and means of implementation” (p. 47). So, ascertaining the teachers' stages of concern and the extent of its implementation is necessary because their concerns or perceived status threats can impede their rate or level of adoption of any new curriculum. The rate of adoption is "the relative speed with which an innovation is adopted by members of a social system" (Rogers, 2003, p. 23), like the school system. It is also necessary to ascertain other factors of concern to teachers that affect their extent of implementation of the curriculum. The rate of adoption for innovation varies among people in different social systems. It is directly affected by the system-related factors and indirect influence of other individual member-related behavior (Rogers, 2003, E., p. 23).

\section{Professional Development Concerns}

The professional development of the prospective implementers is at the heart of any curriculum reform initiative. First, the teacher factor is a critical component of any curriculum innovation. A good curriculum in the hand of an incompetent teacher is as ineffective as the teacher. According to City et al. (2009), "The idea that instruction is at the core of school improvement is typically not a particularly hard sell with educators in this period of high-stakes accountability" (p. 86). Besides, overemphasis on the standards could lead to overlooking the much-needed investment ineffective curriculum and professional developments for teachers (Main, 2012, p. 73; see also McPartland \& Schneider). "Curriculum workers in our current climate," Snow-Gerono of Boise State University noted, "must learn to work within moves toward high-stakes testing and standardization" (as cited in Marshall et al., 2007, p. 274).

Second, cooperation between the school level and district level administrators and teachers, and collaboration among teachers would effectively address teachers' concerns 
regarding the implementation of the Common Core curriculum. Implementation of a coherent and rigorous curriculum requires leadership, cooperation, and collaboration (Reyes \& Lappan, 2007, as cited in Main, 2012, p. 74). Curriculum innovation poses an adaptive challenge-requires solutions that lie in people, teachers in this case. "It is a mistake to go it alone. By creating alliances even before your initiative becomes public, you can increase the probability that both you and your ideas will succeed" (Heifetz \& Linsky, 2004, p. 35).

As noted in the purpose statement, the significance of this study derives also from its prospective benefit of helping to determine the professional development needs of teachers as they grapple with the implementation of the Common Core or any new curriculum. Professional development opportunities for teachers are essential for enhancing their effectiveness in implementing the new curriculum. Investment in teacher expertise and curriculum resources are also very critical, not just investment in welldesigned assessments (Darling-Hammond, 2010, as cited in Main, 2012, p. 74). According to City et al. (2009),

Standards only operate by influencing the level of the content that's actually being taught. Their effect in actual classrooms depends on whether there are materials that reflect the standards, whether teachers know how to teach what the materials and standards require, and whether students find the work they are being asked to do worthwhile and engaging.

What about professional development? One may ask. Professional development works, if it works at all, by influencing what teachers do, not by changing what they think they ought to do or what the professional developers think teachers ought to do. The quality and impact of professional development depend on how teachers are learning what they are being taught and whether they can put them to practice in their classrooms. 
(p. 24). "Rich sources of data exist in schools that can tell compelling stories about equitable and inequitable policies and practices" (Johnson, 2002, p. 162). Administrators can utilize the data in creating and steering professional development for teachers.

The National Association for the Education of Young Children (NAEYC) evokes the ethical responsibility to use standards, noting that full implementation of standards is unattainable without the much-needed policies and funding (NAEYC, 2009, as cited in Main, 2012, pp. 75-76). This study would help in making a funding case for teacher centers across the nation that clamor for money and resources that are need for teacher improvement.

More so, understanding teachers' concerns about the Common Core State Standards or any other curriculum for that matter and the extent to which they implement it is critically important when we consider the obvious. That one or two professional development sessions do not guarantee that they understand it and how to use it correctly in the classroom. According to Hall and Horde (2011),

A frequent problem for teachers and others who are expected to implement new practices is that they are not clear about what they are being asked to do. Even when training materials are provided, there is a big leap from preparing to do something to actually doing it. In the end what teachers do in the classroom may bear little resemblance to what the creators of the change had in mind originally. All [of] the teachers may call it the same thing, but in practice what they do may look very different. (p. 42)

Similarly, concerning the persistent superficial nature of professional development, Ball and Cohen (1999) noted that, "Although a good deal of money is spent on staff development in the United States, most is spent on sessions and workshops that are often intellectually superficial, disconnected from deep issues of curriculum and learning, fragmented and noncumulative" (pp. 3-4, as cited in Fullan, 2001, p. 34). 
In response to the stress imposed on schools by the State mandates for improvement or be taken over by the Board of Education, or even closed down, many schools are in a dilemma of implementing different kinds of programs. Johnson (2002) observed that:

Many low-performing schools suffer from program overload combined with a fragmentation of efforts. Although the goals of the programs appear to be good, they may exacerbate the problems of low achievement. All kinds of 'silver bullet' type programs are adopted, often out of desperation to raise test scores. (Johnson, 2002, p. 199)

Furthermore, the pressure on teachers to implement the Common Core Standards when they had not fully understood the instructional shifts could have rendered the new curriculum vulnerable to misinterpretation and implementation. "Teachers can misinterpret reform and change surface features...but fail to alter their basic approach to teaching ...” (Stigler \& Hiebert, 1999, pp. 106-107, as cited in Fullan, 2001, p. 35). A teacher can implement new curriculum without a change in the teaching approach. Or a teacher even without understanding the underlying conceptions or principles of a new curriculum could alter some teaching behaviors and use the new curriculum materials (Fullan, 2001, p. 39).

From the foregoing, it is obvious that a clear understanding of teachers' stages of concern regarding the Common Core State Standards and to what extent they are using them is critically important. Understanding teachers' stages of concern would help administrators and policymakers to determine and provide the necessary instructional and human resources, as well as the professional development, teachers need to prepare their students for academic success effectively. This is critically important because, "Teachers' concerns, beliefs, and behaviors are situated in their world of practice" (Tsui, 2003, as 
cited in Wang, 2014, p. 25). Moreover, whether change occurs or not is at the individual level (Fullan, 2001, p. 47). So, "Being aware of the concerns" Holloway (2003) noted, "allows those in charge of the innovation to tailor aid given to individuals (p.2).

Finally, it is important to note that a failure to attend to teachers' professional development and expertise as part of the improvement strategy results in low-level teaching of high-level content - a phenomenon that is commonplace in American classrooms (City, et al., 2009, p.25). Curriculum change upsets the instructional content, any change in the curriculum upsets changes in the other elements of the instructional core - the teacher and the students. City, et al. (2009) opined that "Making meaningful and productive changes in instructional practices requires us to confront how they upset and, in some sense, reprogram our past ways of doing things" (p. 22). Heifetz \& Linsky (2004) noted,

For teachers to learn a new set of competencies to help them leave fewer children behind in their classrooms, they may have to endure a temporary loss of confidence as they face the gap between the demands for performance and their current practices. And developing this competence will probably require the school to make adaptive changes as well, adopting new norms of supervision, experimentation, and collaboration". (p. 35)

\section{Government's Response}

The Common Core State Standards, like any curriculum reform before it did not have a safe landing. Sawchuk (2012) noted that "A quiet, sub-rosa fear is brewing among supporters of the Common Core State Standards Initiative that the standards will die the slow death of poor implementation in K-12 classrooms" (p. 4). Ujifusa (2013) noted that:

State education leaders are moving to calm political tempests over the Common Core State Standards by adopting or reaffirming policies aimed at asserting local control over data, curriculum, and materials. But the classroom-level impact of 
those moves could be negligible as states forge ahead on common core implementation. (p. 1)

Politicians and policymakers in response to the pressures of parents, educators, and community members felt compelled to slowly begin to respond to the "collateral damage" caused by high-stakes testing, which has multiple implications such as school closures, demoralizing of students, and teachers. Testing has suddenly become a fundamental issue in local elections (Barlowe \& Cook, 2016, p. 4). In New York, for example, Barlowe and Cook (2016) further noted that Governor Andrew Cuomo, with his legislature, started de-emphasizing high-stakes testing and approved a teacher evaluation system in which standardized test scores would account for up to 50 percent of a teacher's evaluation.

In December 2015, a task force created by the governor and charged to review the Common Core State Standards and their alignment to test standardized tests recommended stopping the use of such assessments in the evaluation of teacher and student performance. The governor embraced the recommendations of the task force (p. 5). However, it remains uncertain whether these recent developments alleviate the concerns of teachers implementing the Common Core State Standards, especially in the wake of the ESSA.

As a concerned English Language Arts teacher, I am aware of the challenges and stress involved in implementing the Common Core State Standards. I am involved in the struggle to implement the curriculum and have many concerns about it. This study provided an outlet for teachers in New York State, to express their concerns to the consumers of this study's findings, especially policymakers and educational administrators. It would help in persuading them to pay more attention to teachers' 
concerns and their professional development needs than to engage in intimidating them with accountability based on students' test scores.

\section{Recommendations for Implementing \\ Common Core State Standards}

Understanding how high schools are responding to the new state accountability policies requires an examination of the internal differences that characterize the comprehensive high school. An examination of how different subjects and departments receive and respond to the common standards and standardized tests is needed.

Also, looking at the evidence at the subject and department levels is needed to understand the kind of changes that are taking place under the current policy shift. And, aggregating or averaging data at the school level may cause loss of data on massive changes taking place at the subject and department level (Siskin, 2003, in Flinders \& Thornton, 2009, p. 319).

Finland's educational system has lessons for societies aspiring for exceptional educational and economic achievements. Finland's educational system fosters a strong connection between education and economic development without downplaying culture

and creativity (Hargreaves, A. \& Shirley, D., 2008, in Ornstein, Pajak, \& Ornstein, 2011, p. 320). It is time for the U.S. education to look outside the book and to other nations about the most productive ways forward (Hargreaves, A. \& Shirley, D., 2008, in Ornstein, Pajak, \& Ornstein, 2011, p. 325). Studies have shown that students perform better on tests when there is an alignment of standards, instructions, and assessment (Smithson \& Collares, 2007, as cited in Mohammed \& Fleck, 2010, p. 132). 
This review is by no means exhaustive. Effort was made to avoid skewing towards the demerits of Common Core State Standards and the accompanying standardized tests. At time of this study, there were limited studies on Common Core States Standards available for this review. For instance, two focused on implementation processes (Supovitz, et al., 2016, p. 1) and on professional/networking resources schools might utilize in developing instructional capacity internally (Polikoff, 2017, p. 1). According to Barshay (2019), children's test scores initially dropped when New York, one of the first states to adopt Common Core standards and administer tougher tests in 2013. But student performance began to improve when teachers had time to develop lesson plans and adjust to new curricula. However, after five years of implementing Common Core standards in high schools, suddenly, the failure rate in high school has increased. There is a need for further investigation on the merits of Common Core State Standards, especially as the State transitions to a new curriculum, the Next Generation.

\section{The Concerns-Based Adoption Model (CBAM)}

The Concern-Based Adoption Model (CBAM) originated from the work of Frances Fuller in 1969 and others in response to the innovation focus approach to educational change that was prevalent in the diffusion and adoption era that characterized the 1960s and 1970s. The CBAM researchers believed that change begins at the individual level, usually the teacher or faculty member. They focused their early efforts on understanding what happens to teachers and university faculty when presented with an innovation. The Stages of Change (SoC), as it developed over time, became the hallmark of CBAM work, providing a framework for understanding the personal side of the change process from the individual point of view. The other diagnostic dimensions of the CBAM 
that emerged were the Levels of Use and Innovation Configuration (Hord, Rutherford, Huling, \& Hall, 1987, as cited in Hall, et al., 2006, p. 1).

The Stages of Concern Questionnaire (SoCQ) development went through a rigorous process to ensure its validity and reliability. The original development lasted three years. Before settling on a final structure, the developers explored several formats and methodologies that resulted in a SoCQ. They tested it for estimates of reliability, internal consistency, and validity with several samples and 11 innovations. It all began in the fall of 1973 when they made the first attempts to assess individuals' concerns about a specified innovation. They developed the first pilot instrument consisting of an openended concerns statement and forced ranking. They also explored variations in openended formats that included the use of Likert scales, adjective checklists, and interview protocols. By the spring of 1974, the researches had identified two strategies for measuring the Stages of Concern about an innovation -primarily a quick-scoring penciland-paper questionnaire, which became the SoCQ. The second strategy involved the development of a clinical instrument that utilized open-ended questions and an objective scoring protocol for classifying individual responses - which became known as the OpenEnded Concerns Statement (Newlove \& Hall, 1976, as cited in George, et al., 2013, p. 11).

In the first step in the SoCQ development, the developers used definitions and scale points in the original Concerns-Based Adoption Model (CBAM) paper to identify the potential statements of concerns about an innovation that could indicate a concern of an individual at a particular stage of adopting and implementing an innovation (Hall, Wallace, \& Dossett, 1973, as cited in George, et al., 2013, p. 11). Of the 544 potential 
statements generated by the staff, ten people used the concerns definitions from the original CBAM paper to sort the statements into eight groups that correspond to the seven Stages of the Concern and one "unacceptable" category. The Q-sort results indicated that at least 400 of the statements were related to a given Stage of Concern, as endorsed by six or more of the judges. Those 400 statements were further edited for redundancy and reworded into complete sentences, thus reduced the number of statements to 195, which were pilot tested in May 1974 with a sample of teachers and college faculty stratified according to years of experience with innovation. They began the construction of the subscales using 363 questionnaires that were returned. Item correlation and factor analysis indicated that seven factors explained more than $60 \%$ of the common variance among the 195 items and that the hypothesized scales corresponded to the factor scales. To validate the scales, people who had completed the pilot questionnaire were selected and interviewed to assess their concerns about the specified innovation. The developers used criteria set by the judges to subjectively correlate these data with a person's classification on the 195-item measure. They reduced the selected five items for each of the seven stages, which resulted in a reduction of the questionnaire to 35 questions following a pilot study (George, et al., 2013, p. 12). 


\begin{tabular}{|c|c|c|}
\hline & $\begin{array}{l}\text { Stages of Concern } \\
\text { (SoC) }\end{array}$ & Expression of Concern \\
\hline 6 & Refocusing & $\begin{array}{l}\text { - I have some ideas about something that would work } \\
\text { even better. }\end{array}$ \\
\hline 5 & Collaboration & $\begin{array}{l}\text { - I am concerned about relating what I am doing with } \\
\text { what my co- workers are doing. }\end{array}$ \\
\hline 4 & Consequence & - How is my use affecting my clients (students)? \\
\hline 3 & Management & $\begin{array}{l}\text { - I seem to be spending all my time getting materials } \\
\text { ready. }\end{array}$ \\
\hline 2 & Personal & - How will using it affect me? \\
\hline 1 & Informational & - I would like to know more about it. \\
\hline 0 & Unconcerned & - How will using it affect me? \\
\hline
\end{tabular}

Figure 4. CBAM's seven Stages of Concern: Typical expression of concern about an innovation. Adapted from Hall \& Hord, 2011, p. 72. 


\section{CHAPTER 3}

\section{METHODOLOGY}

\section{Introduction}

The purpose of this study was to investigate the extent to which teachers in New York were implementing the state common core standards in language arts as well as their concerns about implementation of the standards. In this chapter, I restate the research questions and explained the research design, population and sample, instrumentation, data collection procedures and data analysis strategies.

\section{Research Questions}

1. To what extent do teachers implement the Common Core State Standards?

2. Is the extent of implementation related to school level (middle vs. high school) and years of implementing common core standards?

3. What concerns do New York State English Language Arts teachers have regarding the implementation of the Common Core State Standards (CCSS) and at what stages are their concerns?

4. What relationships exist between teachers' Stages of Concern and their extent of implementation of the Common Core State Standards? 


\section{Research Design}

The design of this study is a non-experimental quantitative design using survey research methodology. Grades 6-12 language arts teachers were requested to complete an online survey consisting of questions related to the extent of implementation of English Language Arts (ELA) common core state standards (CCSS) as well as their stage of concerns for the implementation of these standards.

According to McMillan and Schumacher (2010), the researcher in a survey design either administers a questionnaire to a selected sample of subjects or interviews them to collect data. Educational researchers frequently use surveys to describe attitudes, beliefs, opinions, and other types of information. Usually, survey researches are designed in such a way that information about the population can be inferred from the data obtained from a smaller group of the subjects or sample (pp. 22-23). Polikoff (2017) noted,

At the basic level, it is not obvious how to measure whether teachers are actually implementing the standards. It would be simple to survey representative samples of teachers in CCS state and ask them, 'To what extent are you implementing the Common Core Standards?' (p. 3).

According to Schutt (1996, as cited in McMillan and Schumacher 2010), "Survey research is popular in education, primarily for three reasons: versatility, efficiency, and generalizability" (p.236). McMillan and Schumacher (2010) explain that,

Surveys are versatile because they can be used to investigate almost any problem or questions. Many doctoral dissertation use surveys; state departments of education use surveys to determine levels of knowledge and to ascertain needs in order to plan programs; schools use surveys to evaluate aspects of curriculum or administrative procedures; governmental agencies use surveys to form public policy.

Surveys are popular because credible information from a large population can be collected at a relatively low cost.... Surveys are also efficient because data on many variables can be gathered without substantial increase in time or cost. Also, small samples can be selected from larger populations in ways that permit generalizations to the population. In fact, surveys are often the only means of 
obtaining a representative description of traits, beliefs, attitudes, and other characteristics of the population. Surveys also allow for generalizability across the population, in which subgroups or different contexts can be compared. (p. 236)

\section{Population and Sample}

The population for this study comprised of Grades 6-12 English Language Arts teachers in the New York State Public School system. This study utilized purposeful sampling (a nonprobability sampling approach). Purposeful sampling involves the selection of a group of individuals known as samples from the population, the whole group to which results can be generalized. As a matter of research protocol, upon identification of an accessible population, the researcher must plan and recruit participants for the study from all members of the subpopulation, or a smaller group (Portney \&Watkins, 2000, p. 140). Based on his knowledge of the population, the researcher selects samples judged to possess specific characteristics of that population that would be representative or informative about the research topic. Develis (2012), noted that "A reliable questionnaire that is completed by half of the respondents yields more information than an unreliable questionnaire completed by all respondents" (p. 15).

Accordingly, I surveyed a purposeful sample of fifty-three Grades 6-12 English Language Arts public school teachers, tenured and non-tenured, who have one or more years of Common Core State Standards implementation experience. I recruited the participants through the New York State Union of Teachers (NYSUT) monthly journal, NYSUT United, The New York Daily News, in-person distribution of solicitation cards in New York City public schools, and email distribution of the request for participation. Demographic characteristics of teachers who participated in this study are presented in the next chapter (Chapter 4). 


\section{Instrumentation}

Two instruments were used in this study. The first was the Stages of Concern Questionnaire. The second was a researcher-developed questionnaire (the Extent of Implementation Questionnaire) designed to assess the extent to which teachers were implementing the Common Core State Standards in Language Arts.

\section{The Stages of Concern Questionnaire (SoCQ)}

Concerns regarding the implementation of the Common Core State Standards were studied quantitatively with the Stages of Concern Questionnaire (SoCQ), which is based on the Concern-Based Adoption Model (CBAM) diagnostic components (Stedman 1984; George \& Rutherford, 1978; Mitchell, 1988a; Savage 1992, as cited in Hall et al., 2103, p. 31). Hall et al. (2006) noted that the SoC addresses the affective aspects of change (p. 1).

I used a seven-path Stages of Concern Questionnaire comprising of 35 focused items: Stage 0 (5 items): Unconcerned, which measures aspects of the innovation that teachers are not concerned about; Stage 1 (5 items): Informational, which measures concerns regarding what teachers would like to know about the innovation. In this study, this stage helped to find out the knowledge levels of teachers regarding the Common Core Standards. Stage 2 (5 items): Personal, which measures concerns related to how the use of the innovation would affect the teacher. The concerns expressed in this stage helped to determine to what extend other personal matters were impacting teachers' implementation of the Common Core Standards. Stage 3 (5 items): Management, which measures teachers' concerns about how they spend their time implementing the innovation. The expression of concerns in this stage helped to find out how factors 
related to time and daily work load were impacting their implementation of the curriculum. Stage 4 (5 items): Consequence, which measures concerns regarding how the use of innovation is affecting the students. This stage helped in ascertaining how teachers were developing as reflective practitioners, especially in regards to the impact of their implementation of the curriculum on their students. Stage 5 (5 items): Collaboration, which measures concerns regarding what teachers are doing collaboratively. With the concerns expressed in this stage, we can see the extent to which collaboration was taking place as teachers engaged in the implementation of the Common Core Standards. Last, Stage 6 (5 items): Refocusing, which measures concerns about using alternative ideas teachers have to implement the innovation. Through the concerns expressed in this stage, the extent to which implementation was plateauing was determined. We can see how desirous teachers were about changing the curriculum to something better.

The Stages of Concern scaling technique is 0 to 7 , with 0 rating indicate "irrelevant," ratings between 1 to 2 indicate "Not true of me now," ratings from " 3 , to 5" indicate "Somewhat true of me now," and ratings from 6 to 7 indicate "Very true of me now" as delineated in the Stages of Concern Questionnaire (SoCQ) (George, et al., 2006, pp. 79-81). CBAM was appropriate for this study because, in addition to its compatibility with the study design, many researchers have used this model to study educational innovations (Newman, 2011; Khobili \& O’Toole, 2012; Hollingshead, 2009; Wang, 2014).

\section{Extent of Implementation Questionnaire}

I developed the Extent of Implementation Questionnaire (see Appendix A) to assess the extent to which Grade 6-12 language arts teachers in the State of New 
York were implementing the state common core standards in language arts. The questionnaire consists of 34 items representing 15 core standards: 5 in reading, 5 in writing, 3 in speaking/listening and 2 in language. Each of the 34 item is measured along an 8 points modified Likert scale: 1-never, 2-very rarely (once a month or less), 3-rarely (2-3 times a month), 4-Occasionally (once a week), 5-Somewhat frequently (2-3 times a week), 6-Frequency (once a day), 7-Very frequently (2-3 a day) and 8-Always (more than 3 times a day). Each item began with the stem "I give and emphasize activities that require students to ...”.

\section{Validity and Reliability}

According to McMillan and Schumacher (2010), "It is critical to pilot test both the instructions and the survey before distributing them to the identified sample" (p. 237).

The Stages of Concern Questionnaire

The Stages of Concern Questionnaire (SOCQ) is a widely recognized reliable instrument. "Since its development in the 1970s, researchers, evaluators, and change facilitators have been using the Stages of Concern (SoC) Questionnaire to assess teacher concerns about new programs and practices" (Lulu.com; see also Hall \& Hord, (2011, pp. 282-284). The advantages of the SoCQ technique for assessing concerns include strong reliability and validity and the capability of using it to develop concerns profiles. The SoCQ is particularly useful for formal implementation assessment efforts (Creswell, 2013, p. 81). George, et. al. (2013) discussed quite extensively the development and psychometric properties of the SOCQ (see Chapter 2). 
The Extent of Implementation Questionnaire

The validity of the Extent of Implementation Questionnaire (EIQ) was determined in three phases. In phase 1, during item generation, I ascertain that the items in the EIQ are aligned to the New York State common core standards in language arts. In Phase 2, I asked members of my dissertation committee to determine if the items I generated reasonably reflect the NY state common core standards in language arts. In Phase 3, I recruited eleven (11) grade 6-12 English teachers (language arts and new language) to take the EIQ with the instructions to review the survey instrument items for clarity, relevance to the curriculum-specific standards, and representation of their actual practices in implementing the curriculum. I allowed them the freedom to annotate the instrument with their comments as much as necessary. Each teacher had two weeks to review the tool and personally returned it to me or put it in my mailbox in the main office. Of the eleven teachers recruited, eight (73\%) participated. The remaining three teachers said the tool was clear and relevant to them, but they did not return it. Each teacher holds a master's degree and has implemented and is currently implementing the English Language Arts Common Core State Standards. The average number of years of implementation by the participants is 2.5 years. The average number of years of teaching ELA is 9.75.

Five of the eight of participants claim the frequency scales make sense and added comments that gave more insight into the changes needed to make the instrument more reliable and valid. A summary of the comments from the teachers are reported in Table 1. 
Table 1

Frequency of Implementation Scales

\begin{tabular}{|c|c|c|c|}
\hline Question & Yes & No & Comments \\
\hline $\begin{array}{c}\text { Are the frequency of implementation } \\
\text { scales representative of each time } \\
\text { you teach the Common Core } \\
\text { Standards? }\end{array}$ & 6 & 0 & $\begin{array}{l}\text { - "What about every two } \\
\text { weeks" } \\
\text { - "Looks good! Everything was } \\
\text { clear and concise." }\end{array}$ \\
\hline $\begin{array}{l}\text { Do the frequency scales make sense } \\
\text { to you or not? Please explain. }\end{array}$ & 5 & 0 & $\begin{array}{l}\text { - } \text { "Not for every question. } \\
\text { Maybe having 'daily' as a } \\
\text { choice" } \\
\text { - "I have a problem with 'More } \\
\text { than three times a day' unless } \\
\text { you are referring to all } \\
\text { students that you have on a } \\
\text { daily basis." } \\
\text { "No, they are too restricted. It } \\
\text { does not allow for } \\
\text { differentiation." }\end{array}$ \\
\hline
\end{tabular}

Changes made to the instrument

Based on the comments feedback from the participants, I revised the instrument. The word "Daily" was inserted in wherever applicable in the response options to account for the extent of implementation of the CCSS and differentiation by teachers who teach mixed-grade levels. 'Also, I integrated the suggested phrase "Of all the students I teach daily" into the response option as "Across all classes, I teach.” Figures 5 and 6 below illustrate the response options before and after the pilot test. 
Figure 5

Frequency of Implementation Scales before Pilot Test

\begin{tabular}{cccccccc}
\hline 1 & 2 & 3 & 4 & 5 & 6 & 7 & 8 \\
\hline Never & $\begin{array}{c}\text { Very } \\
\text { Rarely } \\
\end{array}$ & Rarely & Occasionally & Somewhat & Frequently & $\begin{array}{c}\text { Very } \\
\text { Frequently }\end{array}$ & More than \\
& $(2-3$ & $(1$ time/week) & Frequently & (Daily) & & (More than \\
& $/$ & times & & & & $2-3$ & 3 \\
& $\begin{array}{c}\text { Month } \\
\text { or less) }\end{array}$ & /month) & & (2-3Times & & times/Day & times/Day) \\
& & & & & & \\
\hline
\end{tabular}

Figure 6

Frequency of Implementation Scales After Pilot Test

\begin{tabular}{cccccccc}
\hline 1 & 2 & 3 & 4 & 5 & 6 & 7 & 8 \\
\hline \multirow{4}{*}{ Never } & & & & & & & \\
& & & & & & & \\
& Once & Once & Once & 2-3Times & Once & $2-3$ & More \\
& Every & Every & Weekly & Weekly & Daily & Times & than 3 \\
& Month & Second & Across All & Across & Across & Daily & Times \\
& Across & Week & Classes I & All & All & Across & Daily \\
& All & Across & Teach & Classes I & Classes I & All & Across \\
& Classes & All & & Teach & Teach & Classes I & All \\
& I & Classes I & & & & Teach & Classes I \\
& Teach & Teach & & & & & Teach \\
& & & & & &
\end{tabular}

* Implementation of each standard anywhere between scales 5-8 is considered

moderately adequate to strongly adequate. Implementation anywhere below scale 5 is considered inadequate. 


\section{Procedures}

Approval for this study were obtained from the Institutional Review Board at Andrews University once my dissertation committee had approved my proposal. I also obtained approval from the New York City Board of Education. After these approvals, I administered the online battery of questionnaires (SOCQ and EIQ) using Survey Monkey platform with specific instructions that the survey is to be taken only by Grades 6-12 language arts teachers.

The link to the online survey was "https://www.surveymonkey.com/r/NYS_ELA" . Invitation to participate in this study was placed in several media: a website I created for the study (http://commoncorestudy.weebly.com/), publication in the New York State Union of Teachers' monthly journal, NYSUT United, The New York Daily News, and other media services. The first page of the survey contained the informed consent that explicitly stated that it was anonymous and would not impact the participants

psychologically, socially, and economically. It also said that participants were free to optout of any further participation in the study if need be (see Appendix A).

I ensured the protection of participants from psychological risks and guaranteed confidentiality in all phases of this study. I obtained and disclosed to participants IRB approvals from Andrews University and New York City Board of Education to administer a modified Stages of Concern Questionnaire (SoCQ) as well as the Extent of Implementation Questionnaire to participants. In doing this, I complied with the requirement that participants should be adequately informed about the study even though participation through questionnaires and surveys does not require physical interaction with participants (Portney \& Watkins, 2000, p. 312). 


\section{Data Analysis}

1. To what extent do teachers implement the Common Core State Standards?

Descriptive statistics (mean, standard deviation and frequency) were used to determine the extent of implementation of the common core standards. For the purpose of interpretation, raw scores of 1(never) and 2(monthly) are considered inadequate; scores of 3(once biweekly), 4(once a week) and 5 (2-3 a week) are considered moderately adequate; and 6(one a day), 7(2-3 times a day) and 8 (more than 3 times a day) are considered adequate.

2. Is the extent of implementation related to school level (middle vs. high school) and years of implementing common core standards? Independent samples t-test was used to compare middle and high school teachers' levels of implementations. Spearman rho correlation was used to determine the relationship between levels of implementation and years of experience implementing the common core standards. Teachers indicated their years of experience in categories (ordinal).

3. What concerns do New York State English Language Arts teachers have regarding the implementation of the Common Core State Standards (CCSS) and at what stages are their concerns? Frequency distributions were used to determine the stage of concerns with teachers' implementation of the common core standards.

4. What relationships exist between teachers' Stages of Concern and their extent of implementation of the Common Core State Standards? Spearman rho correlation coefficients were used to determine relationship between implementation and stage of concerns. Stages of concerns are assumed to be ordinal. 


\section{Summary}

In this chapter, I restated the purpose and the research questions. I explained the procedure I used to implement the research design I used, how I collected my data and what strategies I used to analyzed the data. In the next chapter, I present the results of my analyses. 


\section{CHAPTER IV}

\section{RESULTS}

\section{Introduction}

The purpose of this study was to examine teachers' implementation of and stages of concern regarding English Language Arts (ELA) Common Core State Standards (CCSS) in New York State. In this chapter, I describe the demographic characteristics of the participants and report the results of the data analyses.

\section{Description of Respondents}

Data presented in 8 indicate 53 teachers participated in this study. Using the electronic survey made diversity in participants possible. Participants represent different gender, ethnicity, and levels of education. The fifty-three participants in this study were primarily female $(66.0 \%)$, white $(62.7 \%)$, and about three-fourths $(73.6 \%)$ have a master's degree with additional credits. Gender wise, $66.0 \%$ seems appropriate considering that usually there are more women in the teaching profession than men. This data is vital because, "In New York, for instance, the demographic difference between teachers and students has jumped five percentage points since 2011” (Boser, 2014). According to Boser (2014), teacher demographics by state and race showed that for New York were White $76 \%$ ), Black (9\%), Hispanic (10\%), other (4\%), and two or more races (11\%) (see Table 2). 
Table 2

Demographic Characteristics: Gender,

Ethnicity, and Level of Education ( $n=53)$

\begin{tabular}{lccc}
\hline & Variable & $\mathrm{N}$ & $\%$ \\
\hline Gender & Male & 12 & 22.6 \\
& Female & 35 & 66.0 \\
& Prefer Not to Answer & 6 & 11.3 \\
\hline Ethnicity & & & \\
& African-American & 7 & 13.7 \\
& Asian & 2 & 3.9 \\
& Hispanic & 4 & 7.8 \\
White & 32 & 62.7 \\
& Other & 6 & 11.8 \\
\hline Level of Education & & \\
& Bachelor's & 1 & 1.9 \\
Master's & 9 & 17.0 \\
& Master's + & 39 & 73.6 \\
Doctorate & 4 & 7.5 \\
& & \\
\hline
\end{tabular}

Also, almost three-fourths of all participants (73.6\%) have a master's degree with additional credits. By established standards, these teachers were "highly qualified" to teach the subject at expected levels of content proficiency. Therefore, their concerns and their extent of implementation of the standards, if taken seriously, could be useful in improving the application of the curriculum. Similarly, age-wise, the participants can be relied upon to give reliable information about their concerns and extent implementation of the curriculum. The average age of the participants is 44.55 years $(\mathrm{SD}=12.48)$.

Another remarkable feature of this study's participants is school-type related diversity. Diversity in the research of this nature is essential in making recommendations 
that would be equitable to all school types. About $60 \%$ of participants in this study were mostly suburban middle and high school teachers (59.6\%), most of whom were certified to teach ELA and ENL, LEP students (86.5\%). They consisted primarily of high school teachers $(69.2 \%)$ and middle school teachers $(30.8 \%)$. General education teachers comprised $62.3 \%$ of the participants. Teachers with $10-19$ years of experience in teaching ELA constituted a more substantial portion of the participants $(84.3 \%)$, and $33.3 \%$ were those with 20 or more years. They were mostly tenured (88.5\%) and are therefore experienced. In terms of implementing the ELA Common Core Standards, $73.1 \%$ of participants had four years of experience (Table 3).

Table 3 shows that participants in this study were mostly suburban teachers (59.6\%), high school teachers $(69.2 \%)$, especially Grade 9 teachers (32.7\%). Most of the participants were certified to teach ELA and ENL, LEP students (86.5\%), and $88.5 \%$ of them were tenured. General education teachers comprised $62.3 \%$ of the participants. Teachers with $10-19$ years of experience in teaching ELA constituted a more significant portion of the participants (84.3\%), and $33.3 \%$ were those with 20 or more years. In terms of implementing the ELA Common Core Standards, $73.1 \%$ of participants had four years of experience.

\section{Analyses of Research Questions}

\section{Question 1}

To what extent do teachers implement the Common Core State Standards? Means and standard deviations for each of the 15 Common Core Standards in language arts are reported in Table 4. Levels of implementation range from a low mean of $3.22(\mathrm{SD}=1.43)$ for response to literature (writing) to a high mean of $6.15(\mathrm{SD}=1.36)$ for key ideas and details (reading). Earlier in Chapter 3, I defined inadequate implementation if teachers 
Table 3

Education-Related Characteristics of Participants $(n=53)$

\begin{tabular}{lrrr}
\hline & Variable & $\mathrm{N}$ & $\%$ \\
\hline Public School Type & & & \\
& Urban & 16 & 30.8 \\
Suburban & 31 & 59.6 \\
Rural & 5 & 9.6 \\
Certified to Teach ELA and/or ENL, LEP students & & \\
Yes & 45 & 86.5 \\
No & 7 & 13.5 \\
Tenure Status & & \\
& Tenured & 46 & 88.5 \\
On Track & 2 & 7.7 \\
Untenured & 4 & 3.8
\end{tabular}

Grade Level(s) Taught

Middle School:

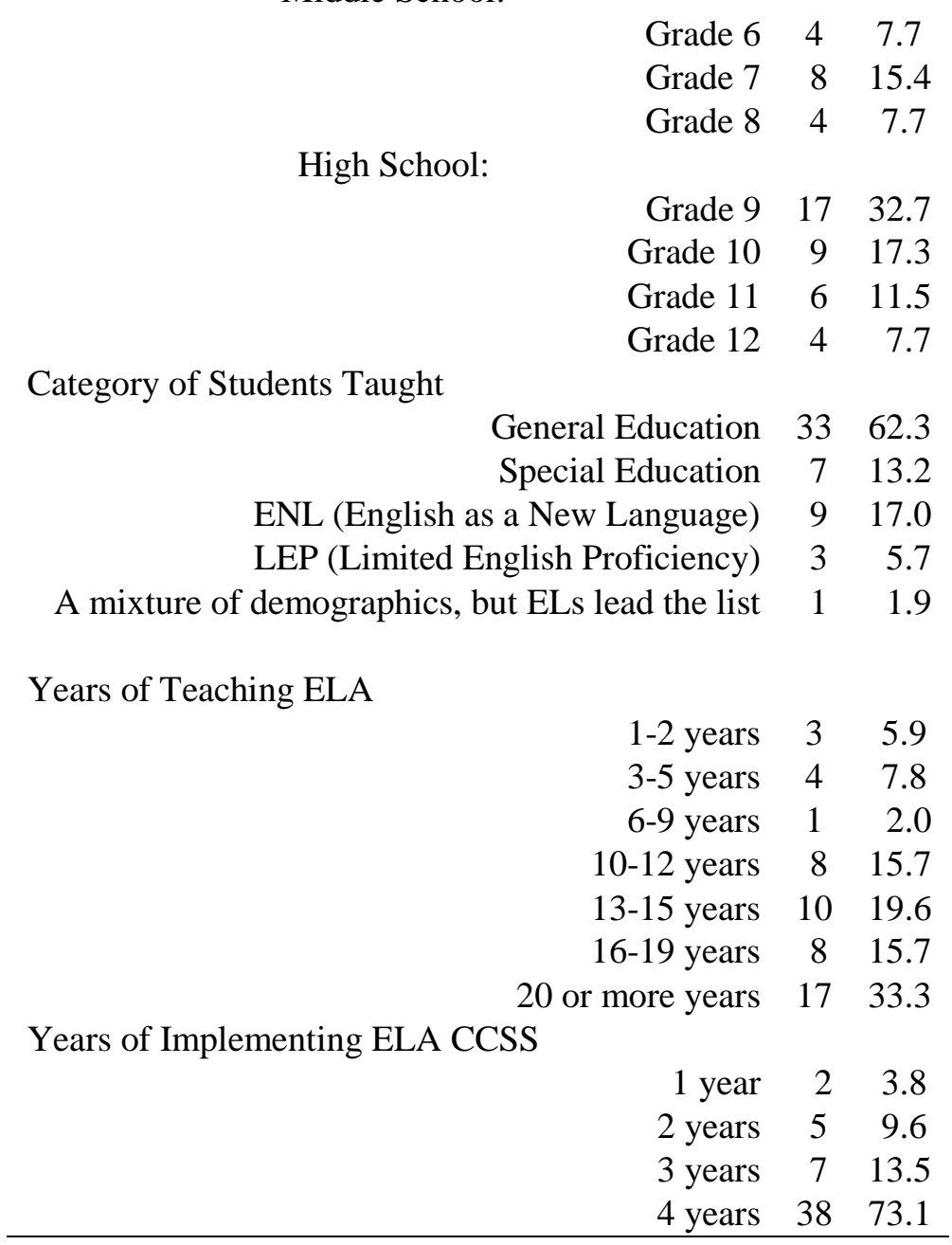


Table 4

Summary of Extent of Implementation

of the Common Core State Standards $(n=53)$

\begin{tabular}{llrrr}
\hline \multirow{1}{*}{ Area } & \multicolumn{1}{c}{ Core Standards } & N & Mean* & SD \\
\hline Reading & Key ideas and details & 53 & 6.15 & 1.36 \\
& Crafts and structures & 53 & 5.57 & 1.66 \\
& Integration of knowledge and ideas & 53 & 4.79 & 1.72 \\
& Range of reading and levels of text & 53 & 5.83 & 1.98 \\
& Complexity & & & \\
& Response to literature & 53 & 5.80 & 1.87 \\
& Text types and purpose & & & \\
Writing & Production and distribution of writing & 53 & 4.02 & 1.85 \\
& Research to build and present knowledge & 53 & 5.37 & 1.68 \\
& Range of writing & 53 & 4.55 & 1.83 \\
& Response to literature & 49 & 3.22 & 1.43 \\
& Comprehension and collaboration & 53 & 5.28 & 1.73 \\
& Presentation of knowledge and ideas & 53 & 4.31 & 2.03 \\
Speaking/Listening & 52 & 6.14 & 1.94 \\
& Conventions of standard English & & & \\
& Knowledge of language & 51 & 5.33 & 2.16 \\
& Vocabulary acquisition and use & 53 & 5.99 & 1.73 \\
& & & & \\
\hline
\end{tabular}

*1=Never, $2=$ once a month, 3=biweekly, 4=weekly, 5=2-3 times/week, $6=$ daily, $7=2-3$ times/day, $8=$ more than 3 times/day

only implement the standards monthly, moderately adequate if they implement them weekly, and adequate if they implement them daily. Thus, means less than 2.5 would be considered inadequate, 2.5 to 5.5 would be moderately adequate and means above 5.5 would be considered as adequate. Using these interpretive criteria, an examination of the results in Table 4 show that teachers implement 9 of the 15 core standards moderately adequately (e.g. Response to the literature $(M=3.22)$ and production and distribution of 
writing (M=5.37). Teachers implement 6 of the 15 core standards adequately (e.g. Crafts and structures $(M=5.57)$ and key ideas and details $(M=6.15)$.

Percent of teachers implementing specific items in each core areas (reading, writing, speaking/listening and language are reported in Tables 5 through 8 . As a reminder, responses of 1 and 2 are considered inadequate, 3-5 are considered moderately adequate and 6-8 are deemed adequate levels of implementation.

\section{Reading Standards (R)}

Levels of implementation of the key elements of the reading core standards are reported in Table 5. Adequate implementation range from a low of $30.2 \%$ for analyzing 'how two or more texts address similar themes' to a high of $84.9 \%$ for "activities that require students to read closely to determine what the text says." A close inspection of the results in Table 5 indicate that approximately $77 \%$ to $98 \%$ of teachers are moderately adequate or adequately implementing the reading core standards.

\section{Writing Standards (W)}

Levels of implementation for the writing standards are reported in Table 6. In only two areas are most teachers adequately implementing: activities requiring students to produce clear and coherent writing (62.3\%) and developing and strengthening the writing process $(54.8 \%)$. More than half of the teachers are inadequately implementing to 'write narratives to develop real or imagined experience or events' $(56.6 \% 0$; ' $g a t h e r$ relevant information from multiple print and digital sources and integrate the information while avoiding plagiarism' $(52.8 \%)$ and 'implement activities that require students to conduct short and sustained research projects' $(67.9 \%)$. 
Table 5

Level of teacher implementation of reading core standards, $(n=53)$

\begin{tabular}{|c|c|c|c|}
\hline Statement & $1^{\mathrm{a}}$ & $2^{b}$ & $3^{\mathrm{c}}$ \\
\hline $\begin{array}{l}\text { (KID)I implement activities that require students to read closely to } \\
\text { determine what the text says explicitly and to make logical inferences } \\
\text { from it, and cite specific textual evidence }\end{array}$ & 3.8 & 11.3 & 84.9 \\
\hline $\begin{array}{l}\text { determine central ideas or themes of a text and analyze their } \\
\text { development; summarize the key supporting details and ideas }\end{array}$ & 1.9 & 34.0 & 64.1 \\
\hline $\begin{array}{l}\text { analyze how and why individuals, events, and ideas develop over the } \\
\text { course of a text. }\end{array}$ & 1.9 & 43.4 & 54.7 \\
\hline $\begin{array}{l}\text { (CS) I implement activities that require students to interpret words and } \\
\text { phrases as they are used in a text, and how specific word choices shape } \\
\text { meaning or tone. }\end{array}$ & 7.5 & 34.0 & 58.5 \\
\hline $\begin{array}{l}\text { analyze the structure of texts, including how specific sentences, } \\
\text { paragraphs, and larger portions of the text relate to each other and the } \\
\text { whole. }\end{array}$ & 9.4 & 43.4 & 47.2 \\
\hline $\begin{array}{l}\text { assess how point of view or purpose shapes the content and style of a } \\
\text { text. }\end{array}$ & 9.4 & 45.3 & 45.3 \\
\hline $\begin{array}{l}\text { (IKI) I implement activities that require students to integrate and } \\
\text { evaluate content presented in diverse formats and media. }\end{array}$ & 15.1 & 52.8 & 32.1 \\
\hline delineate and evaluate the argument and specific claims in a text. & 17.0 & 43.4 & 39.6 \\
\hline analyze how two or more texts address similar themes or topics. & 22.6 & 47.2 & 30.2 \\
\hline $\begin{array}{l}\text { (RLTC) I implement activities that require students to read and } \\
\text { comprehend complex literary and informational texts independently } \\
\text { and proficiently. }\end{array}$ & 11.3 & 30.2 & 58.5 \\
\hline $\begin{array}{l}\text { (RL) I implement activities that require students to respond to literature } \\
\text { by employing knowledge of literary language, textual features, and } \\
\text { forms. }\end{array}$ & 9.4 & 32.1 & 58.5 \\
\hline
\end{tabular}

aPercent 'Not Adequate” bercent 'Moderately adequate" cPercent 'adequate' 
Table 6

Level of teacher implementation of writing core standards, $(n=53)$

apercent 'Not Adequate" 'Percent 'Moderately adequate" 'Percent 'adequate'

$\begin{array}{llll}\text { Statements } & 1^{\mathrm{a}} & 2^{\mathrm{b}} & 3^{\mathrm{c}}\end{array}$

(W-TTP) I implement activities that require students to write arguments

$24.5 \quad 43.4 \quad 32.1$ to support claims in an analysis of topics or texts, using valid reasoning and relevant and sufficient evidence

write informative/explanatory texts to examine and convey complex

$24.5 \quad 47.2 \quad 28.3$ ideas and information clearly and accurately.

write narratives to develop real or imagined experiences or events.

$\begin{array}{lll}56.6 & 28.3 & 15.1\end{array}$

(W-PDW) I implement activities that require students to produce clear and coherent writing.

develop and strengthen writing process

$9.4 \quad 35.8 \quad 54.8$

use technology to produce and publish writing and to interact and

$\begin{array}{lll}35.8 & 34.0 & 30.2\end{array}$

collaborate with others.

(R-RBPK) I implement activities that require students to conduct short

$67.9 \quad 17.0 \quad 15.1$ as well as more sustained research projects based on focused questions.

gather relevant information from multiple print and digital sources, and

$\begin{array}{lll}52.8 & 30.2 & 17.0\end{array}$ integrate the information while avoiding plagiarism.

draw evidence from literary or informational texts to support analysis, reflection, and research.

(W-RW) I implement activities that require students to write routinely

$24.5 \quad 39.6 \quad 35.9$ over extended time frames (reflection and revision) and shorter time frames for a range of tasks, purposes, and audiences.

(W-RL) I implement activities that require students to develop personal,

$34.0 \quad 58.5-7.5$ cultural, and thematic connections across genres. 


\section{Speaking and Listening Standards (SL)}

In Table 7, percent of teachers implementing speaking/listening core standards at three different levels are reported. Over $90 \%$ of the teachers moderately adequately and adequately implemented 'activities that required students to prepare for and participate effectively in a range of conversations and collaborations with diverse partners.' However, only about $60 \%$ implemented making 'strategic use of digital media and visual displays' and 'adapt speed to a variety of contexts and communicative tasks." About $80 \%$ integrated and evaluate 'information presented in diverse media and formats' and implemented 'activities that required students to present information, findings, and supporting evidence'.

\section{State Standards for Language $(\mathrm{L})$}

Levels of implementation for language core standards among the 53 teachers who participated in this study are reported in Table 8 . More than $50 \%$ of the teachers adequately implemented all features of the language core standards. Only $15 \%$ or less implemented them inadequately. Perhaps the best implemented standard is to 'acquire and use accurately a range of general academic and domain-specific words and phrases'. Question 2. Is the extent of implementation related school level (middle vs. high school) and years of implementing common core standards?

\section{Question 2}

\section{School type and reading core standards}

Independent samples t-test was used to determine if there were differences between middle and high school teachers' implementation of the language arts common 
Table 7

Level of teacher implementation of speaking/listening core standards, $(n=53)$

Statements

$1^{\mathrm{a}} \quad 2^{\mathrm{b}} \quad 3^{\mathrm{c}}$

(SL-CC) I implement activities that require students to prepare for and

$\begin{array}{lll}7.5 & 28.3 & 64.2\end{array}$ participate effectively in a range of conversations and collaborations with diverse partners.

integrate and evaluate information presented in diverse media and

$20.8 \quad 39.6 \quad 36.6$ formats.

evaluate a speaker's point of view, reasoning, and use of evidence and

$\begin{array}{lll}11.4 & 50.9 & 37.7\end{array}$ rhetoric.

(PKI) I implement activities that require students to present information, $22.6 \quad 43.4 \quad 34.0$ findings, and supporting evidence such that listeners can follow the line of reasoning and the organization, development, and style.

make strategic use of digital media and visual displays of data to express

$\begin{array}{lll}39.7 & 37.7 & 22.6\end{array}$ information and enhance understanding of presentations.

adapt speed to a variety of contexts and communicative tasks, demonstrating command of formal English when indicated or appropriate.

aPercent 'Not Adequate" 'Percent 'Moderately adequate" 'Percent 'adequate' 
Table 8

Level of teacher implementation of language core standards, $(n=53)$

\begin{tabular}{llll}
\hline Statements & $1^{\mathrm{a}}$ & $2^{\mathrm{b}}$ & $3^{\mathrm{c}}$
\end{tabular}

(CSE) I implement activities that require students to demonstrate

$5.7 \quad 20.8 \quad 73.5$
command of the conventions of standard English grammar and usage when writing or speaking.

demonstrate commend of the conventions of standard English

$11.3 \quad 18.9 \quad 69.8$ capitalization, punctuation, and spelling when writing.

(L-KL) I implement activities that require students to apply knowledge of language to understand how language functions in different contexts, to make effective choices for meaning or style, and to comprehend more fully when reading or listening.

(L-VAU) I implement activities that require students to determine or clarify the meaning of unknown and multiple-meaning words and phrases.

demonstrate understanding of figurative language, word relationships, and nuances in word meanings.

acquire and use accurately a range of general academic and domainspecific words and phrases.

aPercent 'Not Adequate" ' ${ }^{b}$ Percent 'Moderately adequate" cPercent 'adequate'

core standards. Table 9 reports the group means, standard deviations, effect sizes and ttest results for reading. At $\alpha=.05$, there are no statistically significant differences between middle and high schools on all 5 reading core standards. With means at or above 5, middle and high school teachers, on the average, appear to be implementing reading core standards adequately. Effect sizes range from 0.04 for response to literature to 0.33 for key ideas and details. Thus, any differences between middle and high schools are small at best. 
Table 9

School Type Differences on Reading Core Standards $(n=53)$

\begin{tabular}{llllllll}
\hline Core Standards & School Type & N & M & SD & t* & p & ES(d) \\
\hline Key ideas and details & Middle & 16 & 6.52 & .91 & 1.10 & .28 & 0.33 \\
& High & 35 & 6.07 & 1.49 & & & \\
Crafts and structures & Middle & 16 & 5.50 & 1.68 & 0.31 & .76 & 0.09 \\
& High & 35 & 5.66 & 1.71 & & & \\
& Middle & 16 & 5.00 & 1.68 & 0.54 & .59 & 0.16 \\
$\begin{array}{l}\text { Integration of } \\
\text { knowledge and ideas }\end{array}$ & High & 35 & 4.71 & 1.80 & & & \\
$\begin{array}{l}\text { Range of reading and } \\
\text { levels of text }\end{array}$ & Middle & 16 & 5.69 & 2.33 & 0.37 & .71 & 0.11 \\
complexity & High & 35 & 5.92 & 1.88 & & & \\
$\begin{array}{l}\text { Response to literature } \\
\text { Middle }\end{array}$ & High & 16 & 5.75 & 1.91 & 0.14 & .89 & 0.04 \\
& & 35 & 5.83 & 1.93 & & & \\
\hline
\end{tabular}

$* \mathrm{df}=49$

\section{School Type and Writing Core Standards}

In Table 10, means, standard deviations, effect sizes and the Independent samples t-test are summarized for writing core standards. Implementations appear to be slightly higher for middles schools than high schools in text types and purpose, production and distribution of writing, and research to build and present knowledge, but lower in range of writing and response to literature. However, at $\alpha=.05$, there are no statistically 
Table 10

School Type Differences on Writing Core Standards $(n=53)$

\begin{tabular}{|c|c|c|c|c|c|c|c|}
\hline $\begin{array}{c}\text { Core } \\
\text { Standards }\end{array}$ & School Type & $\mathrm{N}$ & $\mathrm{M}$ & SD & $\mathrm{t}^{*}$ & $\mathrm{p}$ & $\mathrm{ES}(\mathrm{d})$ \\
\hline $\begin{array}{l}\text { Text types and } \\
\text { purpose }\end{array}$ & $\begin{array}{l}\text { Middle School } \\
\text { High School }\end{array}$ & $\begin{array}{l}16 \\
35\end{array}$ & $\begin{array}{l}4.25 \\
3.90\end{array}$ & $\begin{array}{l}1.88 \\
1.89\end{array}$ & 0.61 & .55 & 0.18 \\
\hline $\begin{array}{l}\text { Production and } \\
\text { distribution of } \\
\text { writing }\end{array}$ & $\begin{array}{l}\text { Middle School } \\
\text { High School }\end{array}$ & $\begin{array}{l}16 \\
35\end{array}$ & $\begin{array}{l}5.89 \\
5.15\end{array}$ & $\begin{array}{l}1.67 \\
1.68\end{array}$ & 1.47 & .15 & 0.44 \\
\hline $\begin{array}{l}\text { Research to } \\
\text { build and } \\
\text { present } \\
\text { knowledge }\end{array}$ & $\begin{array}{l}\text { Middle School } \\
\text { High School }\end{array}$ & $\begin{array}{l}16 \\
35\end{array}$ & $\begin{array}{l}3.75 \\
3.47\end{array}$ & $\begin{array}{l}1.98 \\
1.82\end{array}$ & 0.50 & .62 & 0.15 \\
\hline $\begin{array}{l}\text { Range of } \\
\text { writing }\end{array}$ & $\begin{array}{l}\text { Middle. School } \\
\text { High School }\end{array}$ & $\begin{array}{l}16 \\
35\end{array}$ & $\begin{array}{l}4.75 \\
5.06\end{array}$ & $\begin{array}{l}2.41 \\
2.14\end{array}$ & 0.46 & .65 & 0.14 \\
\hline $\begin{array}{l}\text { Response to } \\
\text { literature }\end{array}$ & $\begin{array}{l}\text { Middle Sch. } \\
\text { High School }\end{array}$ & $\begin{array}{l}15 \\
32\end{array}$ & $\begin{array}{l}2.80 \\
3.41\end{array}$ & $\begin{array}{l}1.47 \\
1.39\end{array}$ & -1.37 & .18 & 0.41 \\
\hline
\end{tabular}

$* \mathrm{df}=49$

significant differences in the level of implementation between middle and high schools in all 5 writing core standards. Any differences between middle and high schools are small (Effect sizes (d) of .14 to .44.

\section{School Type and Speaking and Listening Core Standards}

The independent samples t-test results for comparing speaking/listening core standards between middle and high school teachers are reported in Table 11. Levels of implementation appear to be slightly higher among middle school teachers in 2 of the 3 
Table 11

School Type Differences on Speaking/Listening Core Standards $(n=53)$

\begin{tabular}{|c|c|c|c|c|c|c|c|}
\hline Core Standards & School Type & $\mathrm{N}$ & M & $\mathrm{SD}$ & $\mathrm{t}^{*}$ & $\mathrm{p}$ & $\mathrm{ES}(\mathrm{d})$ \\
\hline \multirow{2}{*}{$\begin{array}{l}\text { Comprehension and } \\
\text { collaboration }\end{array}$} & Middle & 16 & 5.40 & 2.06 & \multirow[t]{2}{*}{0.28} & \multirow[t]{2}{*}{.78} & \multirow[t]{2}{*}{0.24} \\
\hline & High & 35 & 5.25 & 1.65 & & & \\
\hline \multirow{2}{*}{$\begin{array}{l}\text { Presentation of } \\
\text { knowledge and ideas }\end{array}$} & Middle & 16 & 4.52 & 2.29 & \multirow[t]{2}{*}{0.50} & \multirow[t]{2}{*}{.62} & \multirow[t]{2}{*}{0.15} \\
\hline & High & 35 & 4.21 & 1.98 & & & \\
\hline \multirow{2}{*}{$\begin{array}{l}\text { Conventions of } \\
\text { standard English }\end{array}$} & Middle & 16 & 6.03 & 2.28 & \multirow[t]{2}{*}{-0.15} & \multirow[t]{2}{*}{.89} & \multirow[t]{2}{*}{0.04} \\
\hline & High & 34 & 6.12 & 1.82 & & & \\
\hline
\end{tabular}

standards. Overall, these three core standards appear to be moderately adequately and adequately implemented. However, differences between teachers in the two types of schools are not statistically significant ( $p>.05)$. With effect sizes (ES) from $0.15-0.24$ ), these differences are small.

\section{School Type and Language Core Standards}

Table 12 reports the independent samples t-test results for comparing middle and high school teachers' implementation of the language core standards. With $\mathrm{p}>.05$, there were no statistically significant differences in levels of implementation between teachers of the two types of schools. For example, in this study between middle and high school teachers, there was no statistically significant difference in the implementation of knowledge of the language, $t(49)=-0.31, p>.76$. All the means for the standards in this 
Table 12

School Type Differences on Language Core Standards $(n=53)$

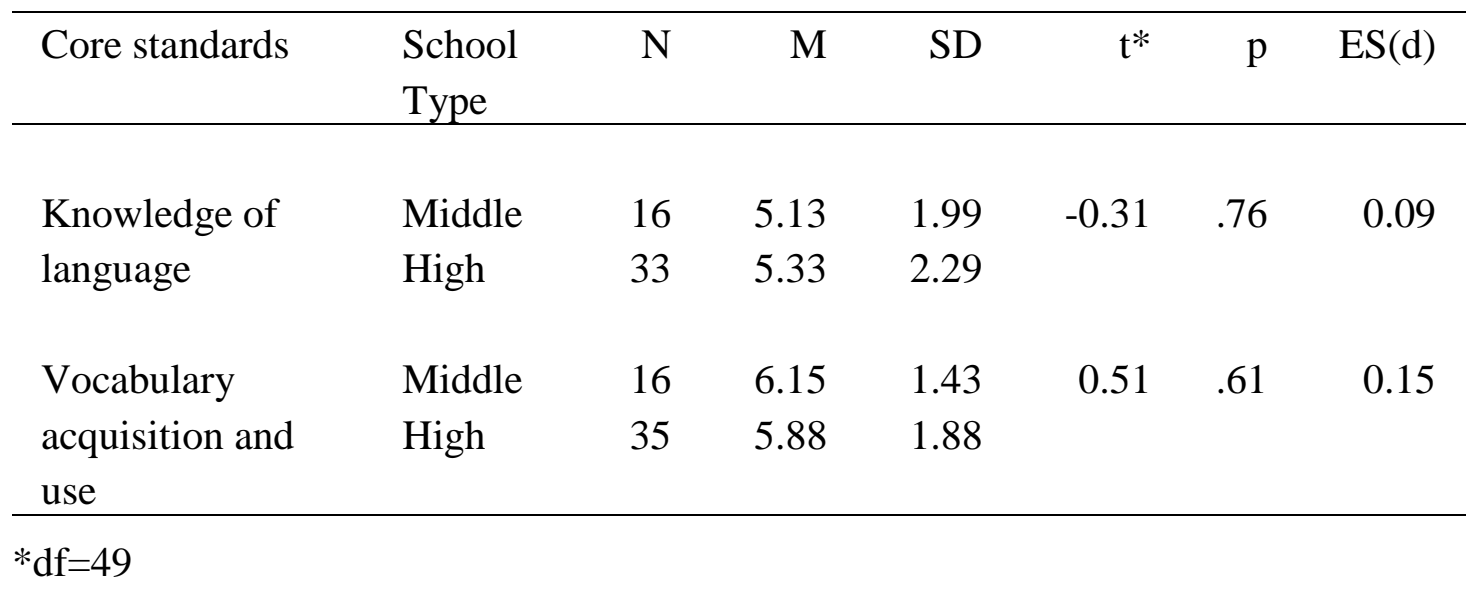

domain were 5 and above in both school levels and indicate adequate implementation. Any differences between middle and high schools were small (ES (d) from $0.04-0.15$ ).

\section{Is the extent of implementation related to} years of implementing common core standards?

Table 13 reports descriptive statistics and spearman rho correlation between the implementation of Common Core Standards and years of experience implementing them. Correlation coefficients are negligible ( $\mathrm{r}=.060$ between 'range of reading and levels of complexity' and years of implementation) to weak ( $r=.339$ between 'key ideas and details' and years of implementation'). Only two correlation coefficients are statistically significant $(\mathrm{p} \leq .05)$ : between years of implementation and key ideas/details $(\mathrm{r}=.339)$ and production and distribution of writing $(\mathrm{r}=.307)$. These results seem to suggest that 
Table 13

Spearman rho correlation between core standards

and years of teaching experience $(n=53)$

\begin{tabular}{llrrrr}
\hline \multicolumn{1}{c}{ Area } & \multicolumn{1}{c}{ Core Standards } & N & Mean & SD & \multicolumn{1}{c}{$\mathrm{r}$} \\
\hline Reading & Key ideas and details & 53 & 6.15 & 1.36 & $.33 *^{*}$ \\
& Crafts and structures & 53 & 5.57 & 1.66 & .164 \\
& Integration of knowledge and ideas & 53 & 4.79 & 1.72 & .150 \\
& Range of reading and levels of text & 53 & 5.83 & 1.98 & .060 \\
& complexity & & & & \\
& Response to literature & 53 & 5.80 & 1.87 & .265 \\
Writing & Text types and purpose & 53 & 4.02 & 1.85 & .178 \\
& & & & & \\
& Production and distribution of writing & 53 & 5.37 & 1.68 & $.307 *$ \\
& Research to build and present knowledge & 53 & 3.55 & 1.83 & .099 \\
& Range of writing & 53 & 4.87 & 2.22 & .190 \\
Speaking/Listening & 49 & 3.22 & 1.43 & .145 \\
& Response to literature & 53 & 5.28 & 1.73 & .113 \\
& Comprehension and collaboration & & & & \\
& Presentation of knowledge and ideas & 53 & 4.31 & 2.03 & .158 \\
& Conventions of standard English & 52 & 6.14 & 1.94 & .085 \\
Language & Knowledge of language & 51 & 5.33 & 2.16 & .179 \\
& & & & & \\
& Vocabulary acquisition and use & 53 & 5.99 & 1.73 & .202 \\
\hline
\end{tabular}

implementation of the Common Core Standards were not related to the number of years teachers have been implementing them.

\section{Question 3}

What concerns do New York State English Language Arts teachers have regarding the implementation of the Common Core State Standards (CCSS) and at what stages are their concerns? The stages of concern questionnaire (SOCQ) consists of 35 items measuring 7 stages of concerns (0 to 6). Each stage is measured by 5 items. Score for each stage is 
computed by taking the sum of the responses such that each stage can have a range of scores from 0 to 30 . The stage of concern for each participant is then determined by using the stage with the largest sum. If the sum scores are tied, we used the sum score associated with the higher stage. For example, if Teacher A has the following sum scores for each stage: $0-22,1-20,2-28,3-24,4-28,5-28,6-18$, then he/she would be assigned a Stage 5 concern.

Using these scoring criteria, Table 14 reports the percent of teachers at each of the stage of concern. Approximately 50 percent of the teachers were in Stages 4 through 6, at which they were concern about how implementation affect their students, and colleagues. The remaining half were concerned about implementations affect them personally. Item level statistics for each stage are reported in Tables 15-21.

\section{Concern Stage 0}

Table 15 shows that all five Stage 0 concerns were somewhat true among the five teachers in this stage. For example, a little over one-fourth $(26.4 \%, \mathrm{M}=3.62, \mathrm{SD}=2.2)$ of teachers in Stage 0 was preoccupied with things other than the innovation, making this the most expressed concern of the five teachers. And less than one-fourth $(17.3 \%$, $\mathrm{M}=2.88, \mathrm{SD}=2.21$ ) was not concerned at about the innovation, making this the least expressed Stage 0 concern. Teachers who expressed Stage 0 concerns can be described as late adopters.

\section{Concern Stage 1}

As shown in Table 16, four of the five Stage 1 concerns were somewhat true among the six teachers in this stage $(32.1 \%, \mathrm{M}=3.17, \mathrm{SD}=2.54$ to $50.9 \%, \mathrm{M}=4.49 \%$, 
Table 14

Percent of teachers at different stages of concern $(n=53)$

\begin{tabular}{llrr}
\hline Stage & \multicolumn{1}{c}{ Expression of concern } & n & \% \\
\hline 0 & How will it affect me? & 5 & 9.4 \\
1 & I would like to know more about it. & 6 & 11.3 \\
2 & How will using it affect me? & 12 & 22.6 \\
3 & I seem to be spending all my time getting materials ready. & 2 & 3.8 \\
4 & How is my use affecting my students? & 11 & 20.8 \\
5 & I am concerned about relating what I am doing with what my & 12 & 22.6 \\
& coworkers are doing. & & \\
6 & I have some ideas about something that would work even & 5 & 9.4 \\
& better & & \\
\hline
\end{tabular}

Table 15

Unconcerned (Self): Little concern about or involvement with the CCSS innovation

\begin{tabular}{|c|c|c|c|c|}
\hline Innovation Statement & $\mathrm{N}$ & M & SD & $\%$ \\
\hline $\begin{array}{l}21 \text { In terms of the Common Core State Standards as an } \\
\text { innovation I am preoccupied with things other than } \\
\text { the innovation }\end{array}$ & 53 & 3.62 & 2.22 & 26.4 \\
\hline 3 I am more concerned about another innovation & 52 & 3.17 & 2.42 & 30.8 \\
\hline $\begin{array}{l}30 \text { Currently, other priorities prevent me from focusing } \\
\text { My attention on the innovation. }\end{array}$ & 53 & 3.11 & 2.43 & 32.1 \\
\hline 12 I am not concerned about the innovation at this time. & 53 & 2.94 & 2.42 & 26.4 \\
\hline 23 I spend little time thinking about the innovation. & 52 & 2.88 & 2.21 & 17.3 \\
\hline
\end{tabular}


Table 16

Informational (Self): A general awareness of the CCSS

and interest in learning more details about it $(n=53)$

Innovation Statement

$\mathrm{N} \quad \mathrm{M} \quad \mathrm{SD} \quad \%$

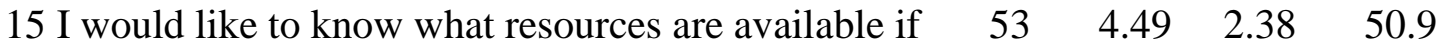

we decide to adopt the innovation.

35 I would like to know how the innovation is better

than what we have now/used to have.

$\begin{array}{llll}53 & 4.34 & 2.5 & 49.1\end{array}$

26 In terms of the Common Core State Standard as an innovation I would like to know what the use of the

$\begin{array}{llll}53 & 4.25 & 2.27 & 41.5\end{array}$

innovation will require in the immediate future.

14 I would like to discuss the possibility of using the $\begin{array}{llll}53 & 3.17 & 2.54 & 32.1\end{array}$ innovation.

6 In terms of the Common Core State Standards as an innovation I have a very limited knowledge of the innovation.

$\%$ (3-7) Somewhat to Very True of Me Now

$\mathrm{SD}=2.38)$. Stage 1 concern about knowing what resources were available when teachers decide to adopt the innovation was the most expressed Concern $(50.9 \%, \mathrm{M}=4.49, \mathrm{SD}=$ 2.38). On the contrary, Stage 1 concern about having "very limited knowledge of the innovation" was not somewhat true within the six teachers $(15.1 \%, \mathrm{M}=2.11, \mathrm{SD}=1.94)$, making it the least expressed Stage 1 concern.

Teachers in Stage 1 had a general knowledge of the curriculum and interest in learning more details about it. They were not concerned about other personal interests or priorities like those teachers in Stage 0 who represent late adopters. Stage 1 teachers represent early adopters and would benefit from targeted professional development. 


\section{Concern Stage 2}

In Table 17, all Stage 2 concerns were somewhat true among the twelve teachers in this stage $(26.4 \%, \mathrm{M}=96, \mathrm{SD}=2.42$ to $60.4 \%, \mathrm{M}=4.87, \mathrm{SD}=2.41)$. Stage 2 concern about knowing who would make decisions in the new system was the most expressed concern $(60.4 \%, \mathrm{M}=4.87, \mathrm{SD}=2.41)$. Stage 2 concern about knowing the effect of reorganization on teachers' professional status was the least expressed Stage 2 concern $(26.4 \%, \mathrm{M}=96, \mathrm{SD}=2.42)$. Stage 2 teachers' concern was not just about learning more details about the curriculum like teachers in Stage 1. Beyond Stage 1 concerns, they were interested in knowing more about the demands of the curriculum innovation, their adequacy to meet them, and the roles they were expected to play. Teachers in Stage 2 also represent early adopters and would benefit from targeted professional development.

Table 17

Personal (Self): Uncertainty about the demands of the CCSS, adequacy to meet them, and roles $(n=53)$

\begin{tabular}{|c|c|c|c|c|}
\hline Innovation Statement & $\mathrm{N}$ & $\mathrm{M}$ & SD & $\%$ \\
\hline $\begin{array}{l}13 \text { I would like to know who will make decisions in the } \\
\text { new system. }\end{array}$ & 53 & 4.87 & 2.41 & 60.4 \\
\hline $\begin{array}{l}28 \text { I would like to have more information on time and } \\
\text { energy commitments required by the innovation. }\end{array}$ & 53 & 4.19 & 2.35 & 43.4 \\
\hline $\begin{array}{l}33 \text { I would like to know how my role will change when I } \\
\text { am using the innovation. }\end{array}$ & 53 & 3.85 & 2.51 & 41.5 \\
\hline $\begin{array}{l}17 \text { I would like to know how my teaching or } \\
\text { administration is supposed to change. }\end{array}$ & 53 & 3.85 & 2.42 & 41.5 \\
\hline $\begin{array}{l}7 \text { I would like to know the effect of reorganization on my } \\
\text { professional status. }\end{array}$ & 53 & 2.96 & 2.42 & 26.4 \\
\hline
\end{tabular}




\section{Concern Stage 3}

The data presented in Table 18 shows that among the two participants who were in Concern Stage 3, four of the five concerns for this stage were somewhat true of them (26.4\%, $\mathrm{M}=3.43, \mathrm{SD}=2.40$ to $50 \%, \mathrm{M}=4.33, \mathrm{SD}=2.53$ ). Having enough time to organize self each day was the most expressed Stage 3 concern $(50 \%, \mathrm{M}=4.33, \mathrm{SD}=$ 2.53). The conflict between teachers' interests and their responsibilities was not true of the two teachers in this stage of concern $(4.5 \%, \mathrm{M}=2.14, \mathrm{SD}=1.66)$; hence the least expressed concern. Teachers in this stage were one step ahead of the Stage 2 teachers. Beyond trying to figure out their adequacy and roles in implementing the curriculum, teachers in Concern Stage 3 had started reflecting on management demands of the innovation - the processes and tasks using the curriculum and how to utilize information and resources available to them effectively.

\section{Concern Stage 4}

Concern Stage 4 is the first of the three impact stages of the Concerns-Based Adoption Model (CBAM). Table 19 shows that all Stage 4 concerns were Somewhat True of among the eleven teachers in this stage (35.8\%, M=3.74, SD=2.32 to 51.9\%, $\mathrm{M}=4.60, \mathrm{SD}=2.49$ ). Concern about how innovation affects students was the most expressed of the five concerns in this stage (51.9\%, M=4.60, SD =2.49). Concern about students' attitudes toward to curriculum innovation was the least expressed concern (35.8\%, $\mathrm{M}=3.74, \mathrm{SD}=2.32)$. Teachers in this stage were one step ahead of those in Stage

3. Teachers in this stage were reflecting on the impact of their implementation of the curriculum on their students. 
Table 18

Management (Task): Focuses on the processes and tasks using the CCSS and the best use of information and resources $(n=53)$

\begin{tabular}{|c|c|c|c|c|}
\hline Innovation Statement & $\mathrm{N}$ & $\mathrm{M}$ & SD & $\%$ \\
\hline $\begin{array}{l}4 \text { I am concerned about not having enough time to organize } \\
\text { myself each day. }\end{array}$ & 52 & 4.33 & 2.53 & 50.0 \\
\hline $\begin{array}{l}25 \text { I am concerned about time spent working with } \\
\text { nonacademic problems related to the innovation. }\end{array}$ & 52 & 3.6 & 2.38 & 30.8 \\
\hline $\begin{array}{l}16 \text { In terms of the Common Core State Standards as an } \\
\text { innovation I am concerned about my inability to manage all } \\
\text { that the innovation requires. }\end{array}$ & 53 & 3.45 & 2.52 & 32.1 \\
\hline $\begin{array}{l}34 \text { Coordination of tasks and people is taking too much of my } \\
\text { time. }\end{array}$ & 53 & 3.43 & 2.40 & 26.4 \\
\hline $\begin{array}{l}8 \mathrm{I} \text { am concerned about conflict between my interests and my } \\
\text { responsibilities. }\end{array}$ & 44 & 2.14 & 1.66 & 4.5 \\
\hline
\end{tabular}

Table 19

Consequence (Impact): Focuses on the impact of CCSS

on students in teacher's immediate sphere of influence $(n=53)$

\begin{tabular}{lrrrr}
\hline \multicolumn{1}{c}{ Innovation Statement } & $\mathrm{N}$ & $\mathrm{M}$ & $\mathrm{SD}$ & $\%$ \\
\hline $\begin{array}{l}\text { 11 In terms of the Common Core State Standards as an } \\
\text { innovation I am concerned about how the innovation } \\
\text { affects students. }\end{array}$ & 4.60 & 2.49 & 51.9 \\
$\begin{array}{l}\text { 24 I would like to excite my students about their part in } \\
\text { this approach. }\end{array}$ & 50 & 4.22 & 2.30 & 44.0 \\
$\begin{array}{l}32 \text { I would like to use feedback from students to change } \\
\text { the program. }\end{array}$ & 53 & 4.19 & 2.26 & 45.3 \\
$\begin{array}{l}19 \text { I am concerned about evaluating my impact on } \\
\text { students. }\end{array}$ & 53 & 4.17 & 2.24 & 37.7 \\
$\begin{array}{l}1 \text { In terms of the Common Core State Standards as } \\
\text { innovation I am concerned about students' attitude } \\
\text { toward to innovation. }\end{array}$ & 53 & 3.74 & 2.32 & 35.8 \\
\end{tabular}

\% (3-7) Somewhat to Very True of Me Now 


\section{Concern Stage 5}

Concern Stage 5 is the second of the four impact stages of the CBAM. In Table 20 , we see that the four expressions of concern in this stage were somewhat true among the twelve teachers in this stage. Teachers' concern about how to coordinate their efforts with others to maximize the innovation's effects was the most expressed of the four concerns in this stage $(39.6 \%, \mathrm{M}=2.32, \mathrm{SD}=39.6)$. Teachers in this stage were least concerned about familiarizing other departments or persons with the progress of this curriculum innovation $(26.4 \%, \mathrm{M}=2.43, \mathrm{SD}=26.4)$. Teachers in Concern Stage 5 were one step ahead of those in Stage 4. These teachers were concerned about how to coordinate and cooperate with their colleagues in implementing the curriculum.

Table 20

Collaboration (Impact): Focuses on coordinating and cooperating with others regarding use of the CCSS $(n=53)$

\begin{tabular}{|c|c|c|c|c|}
\hline Innovation Statement & $\mathrm{N}$ & $M$ & SD & $\%$ \\
\hline $\begin{array}{l}27 \text { I would like to coordinate my efforts with others to } \\
\text { maximize the innovation's effects. }\end{array}$ & 53 & 4.11 & 2.32 & 39.6 \\
\hline $\begin{array}{l}10 \text { I would like to develop working relationships with both } \\
\text { our faculty and outside faculty using this innovation. }\end{array}$ & 53 & 3.70 & 2.37 & 32.1 \\
\hline $\begin{array}{l}5 \text { I would like to help other faculty in their use of the } \\
\text { innovation. }\end{array}$ & 52 & 3.63 & 2.26 & 30.8 \\
\hline $\begin{array}{l}18 \text { I would like to familiarize other departments or persons } \\
\text { with the progress of this new approach. }\end{array}$ & 53 & 3.04 & 2.43 & 26.4 \\
\hline Valid N (listwise) & 51 & & & \\
\hline
\end{tabular}

\% (3-7) Somewhat to Very True of Me Now 


\section{Concern Stage 6}

Stage 6 is the last impact and the highest stage of concern in the CBAM. The data in Table 21 shows that all five expressions of concern in this stage were somewhat true among the six teachers in this stage. The most expressed concern in this stage was knowledge of some other approaches that might work better than the Common Core Standards $(50.9 \%, \mathrm{M}=4.38, \mathrm{SD}=2.32)$. Teachers in Stage 6 concern were least concerned about revising their use of the curriculum $(17.0 \%, \mathrm{M}=2.60, \mathrm{SD}=2.04)$. Teachers in Concern Stage 6 were one step ahead of those in Stage 5. These teachers appear to have plateaued and were refocusing - exploring ways to other ways to reap more universal benefits from the curriculum, make significant changes to it, or replace it with a more robust alternative.

Table 21

Refocusing (Impact): Focuses on exploring ways to reap more universal benefits from the CCSS, making major changes to it or replacing it with a more powerful alternative $(n=53)$

\begin{tabular}{|c|c|c|c|c|}
\hline Innovation Statement & $\mathrm{N}$ & M & SD & $\%$ \\
\hline $\begin{array}{l}2 \text { I now know some of the other approaches that might } \\
\text { work better. }\end{array}$ & 53 & 4.38 & 2.32 & 50.9 \\
\hline $\begin{array}{l}22 \text { I would like to modify our use of the innovation based } \\
\text { on the experiences of our students. }\end{array}$ & 53 & 4.00 & 2.11 & 34.0 \\
\hline $\begin{array}{l}31 \text { In terms of the Common Core State Standard as an } \\
\text { innovation I would like to determine how to supplement, } \\
\text { enhance, or replace the innovation. }\end{array}$ & 53 & 3.96 & 2.11 & 35.8 \\
\hline 20 I would like to revise the innovation's approach. & 53 & 3.62 & 2.45 & 34.0 \\
\hline 9 I am concerned about revising my use of the innovation. & 53 & 2.60 & 2.04 & 17.0 \\
\hline
\end{tabular}

$\%$ (3-7) Somewhat to Very True of Me Now 


\section{Question 4}

\section{Relationship Between Teachers' Stages of Concern and Their Extent of}

Implementation of the Common Core State Standards. Table 22 show means, standard deviations of implementations of common core standards, and their correlations with the stage of concern. Correlations between stage of concern and implementation of core standards were statistically significant for 'range of reading and levels of text complexity' $(\mathrm{r}=.331)$ and 'response to literature' $(\mathrm{r}=.314)$. There were no statistically significant correlations between stages of concern and the remaining core standards. These results suggest that a higher frequency of implementation of the two core standards (range of reading/levels of text complexity and response to literature) were associated with higher stages of concerns.

\section{Summary of Key Findings}

\section{Research Question 1}

To what extent do teachers implement the Common Core State Standards? Overall, levels of implementation of the 15 Common Core Standards range from moderately adequate, low mean 3.22 ( $\mathrm{SD}=1.43$ to adequate, a high mean of $6.15(\mathrm{SD}=1.36)$. Teachers implement 9 of the 15 core standards moderately adequately and 6 of the 15 core standards adequately. Percent of teachers implementing specific items in each core areas (reading, writing, speaking/listening and language) reported in Tables 6 through 9 are as follows: 
Table 22

Spearman Rho Correlation between Implementation

of Core Standards and Stage of Concern $(n=53)$

\begin{tabular}{|c|c|c|c|c|c|}
\hline Area & Core Standards & $\mathrm{N}$ & Mean & $\mathrm{SD}$ & $\mathrm{r}$ \\
\hline \multirow[t]{5}{*}{ Reading } & Key ideas and details & 53 & 6.15 & 1.36 & .131 \\
\hline & Crafts and structures & 53 & 5.57 & 1.66 & .078 \\
\hline & Integration of knowledge and ideas & 53 & 4.79 & 1.72 & .030 \\
\hline & $\begin{array}{l}\text { Range of reading and levels of text } \\
\text { complexity }\end{array}$ & 53 & 5.83 & 1.98 & $.331 *$ \\
\hline & Response to literature & 53 & 5.80 & 1.87 & $.314 *$ \\
\hline \multirow[t]{5}{*}{ Writing } & Text types and purpose & 53 & 4.02 & 1.85 & .032 \\
\hline & Production and distribution of writing & 53 & 5.37 & 1.68 & .093 \\
\hline & Research to build and present knowledge & 53 & 3.55 & 1.83 & .067 \\
\hline & Range of writing & 53 & 4.87 & 2.22 & .113 \\
\hline & Response to literature & 49 & 3.22 & 1.43 & .109 \\
\hline \multirow[t]{3}{*}{ Speaking/Listening } & Comprehension and collaboration & 53 & 5.28 & 1.73 & -.024 \\
\hline & Presentation of knowledge and ideas & 53 & 4.31 & 2.03 & .114 \\
\hline & Conventions of standard English & 52 & 6.14 & 1.94 & .230 \\
\hline \multirow[t]{2}{*}{ Language } & Knowledge of language & 51 & 5.33 & 2.16 & .165 \\
\hline & Vocabulary acquisition and use & 53 & 5.99 & 1.73 & .167 \\
\hline
\end{tabular}

\section{Reading:}

a. Approximately $77 \%$ to $98 \%$ of teachers were moderately adequate or adequately implementing the reading core standards.

b. Adequate implementation range from a low of $30.2 \%$ for analyzing 'how two or more texts address similar themes to a high of $84.9 \%$ for "activities that require students to read closely to determine what the text says." 


\section{Writing:}

a. Most teachers were adequately implementing activities in two areas: activities requiring students to produce clear and coherent writing $(62.3 \%)$ and developing and strengthening the writing process $(54.8 \%)$.

b. More than half of the teachers were inadequately implementing to 'write narratives to develop real or imagined experience or events' $(56.6 \% 0$; 'gather relevant information from multiple print and digital sources and integrate the information while avoiding plagiarism' (52.8\%) and 'implement activities that require students to conduct short and sustained research projects' $(67.9 \%)$.

\section{Speaking/Listening:}

a. Over $90 \%$ of the teachers moderately adequately and adequately implemented 'activities that required students to prepare for and participate effectively in a range of conversations and collaborations with diverse partners.'

b. Only about $60 \%$ implemented making 'strategic use of digital media and visual displays' and 'adapt speed to a variety of contexts and communicative tasks."

c. About $80 \%$ integrated and evaluate 'information presented in diverse media and formats' and implemented 'activities that required students to present information, findings, and supporting evidence'.

\section{Language:}

a. More than $50 \%$ of the teachers adequately implemented all items of the language core standards.

b. Only $15 \%$ or less implemented them inadequately. 
c. The best implemented standard is to 'acquire and use accurately a range of general academic and domain-specific words and phrases'.

\section{Research Question 2}

Is the extent of implementation related to school level (middle vs. high school) and years of implementing common core standards?

School Type and Reading: At $\alpha=.05$, there are no statistically significant differences between middle and high schools on all 5 reading core standards. With means at or above 5, middle and high school teachers, on the average, appear to be implementing reading core standards adequately.

School Type and Writing: Implementations appear to be slightly higher for middles schools than high schools in text types and purpose, production and distribution of writing, and research to build and present knowledge, but lower in range of writing and response to literature. However, at $\alpha=.05$, there are no statistically significant differences in the level of implementation between middle and high schools in all 5 writing core standards.

School Type and Speaking and Listening: Levels of implementation appear to be slightly higher among middle school teachers in 2 of the 3 standards. Overall, these three core standards appear to be moderately adequately and adequately implemented. However, differences between teachers in the two types of schools are not statistically significant ( $>$.05). 
School Type and Language: With $p>.05$, there are no statistically significant differences in levels of implementation between teachers of the two types of schools. All the means for the standards in this domain were 5 and above in both school levels and indicate adequate implementation.

Implementation and Years of Experience: Overall, at $\mathrm{p} \leq .05$, only two correlation coefficients are statistically significant $(\mathrm{p} \leq .05)$ : between years of implementation and key ideas/details ( $\mathrm{r}=.339)$ and production and distribution of writing $(\mathrm{r}=.307)$.

Correlation coefficients are negligible $(\mathrm{r}=.060$ between 'range of reading and levels of complexity' and years of implementation) to weak ( $\mathrm{r}=.339$ between 'key ideas and details' and years of implementation'). These results seem to suggest that implementation of the Common Core Standards is not related to teachers' years of experience with implementing them.

\section{Research Question 3}

What concerns do New York State English Language Arts Teachers have regarding the Implementation of the Common Core State Standards (CCSS) and at what stages are their concerns? Approximately 50\% of the teachers were in Stage 4 through 6 in which teachers were concerned about how the implementation of the core standards affects their students and their colleagues and that they may have better ideas of implementing the standards. 


\section{Research Question 4}

What relationships exist between teachers' Stages of Concern and their extent of implementation of the Common Core State Standards? Overall, there are no correlations between implementation of core standards stage of concern. 


\section{CHAPTER V}

\section{SUMMARY, DISCUSSION, CONCLUSIONS, IMPLICATIONS,}

AND RECOMMENDATIONS

\section{Introduction}

This chapter comprises of four sections - summary of the study, discussion of findings and conclusions drawn from the data, implications for teaching and learning, and recommendations for future research.

\section{Summary of the Problem}

The Common Core State Standards were crafted to ensure equitable educational opportunities for all students. But the hasty adoption and implementation of the curriculum and the associated high-stakes testing and the corresponding punitive accountability measures are controversial. Educators across the nation feel unsafe in their jobs because of the punitive use of students' test scores on Common Core assessments and graduation rates. According to Rock (2008) the awareness of a possible or real reduction in status can cause a strong threat reaction (pp. 3-4). "Faced with curricular controversy, which appears to be a normal corollary in a democratic society, teachers need a strong, valid response (Maxwell \& Meiser, 2001, P. 37). Understanding teachers' stages of concern as they grapple with the implementation of the curriculum is necessary to determine the trajectory of their learning, understanding, and extent to which 
they are implementing the curriculum, and what to do to help them to implement the curriculum effectively and comfortably. McMurrer and Frizzell's (2013) evaluation of efforts that were being made to implement the Common Core Standards, its adoption, and diffusion focused on the administration and implementation of the curriculum.

Unfortunately, there were no studies on teachers' stages of concerns and the extent to which they were implementing the Common Core Standards. Hence the purpose of this study is to examine teachers' implementation of and stages of concern regarding English Language Arts (ELA) Common Core State Standards (CCSS) in New York State.

\section{Summary of the Literature}

Curriculum is the arrangement of subjects, a structure of prescribed knowledge (Maxine Green, 1971, in Flinders \& Thornton, 2009, p. 155). Historically, the politics of curriculum reform and standards movement in the United States is not new. As a result, the search for the issues and implementation challenges Common Core State Standards and standardized testing was broad-based. I reviewed studies and articles on standardbased curriculum and instruction to understand the general curriculum issues and implementation challenges that characteristically relate to the Common Core State Standards reform and testing. This study's problem and rationale are bounded within a historical framework of reference which includes trends in curriculum development in the United States, implementation and teaching concerns, and testing and evaluation concerns.

School reform is not a new phenomenon in America. According to Longstreet (1993, as cited in Marshall et al., 2007), "Every few years, a major movement of some kind appears" (p. 269). Raising the standards of learning through schooling has become 
an important national priority that has caught the attention of many nations in recent years, causing governments, the world over, to vigorously pursue this goal (Black \& William, 1998). Curriculum scholars have noted that the dissatisfaction with the performance of American schools, when compared to other nations ushered in another wave of education reform, the Common Core Standards. This wave is similar to those of the mid-1980s: A Nation at Risk in 1983, America 2000 in 1987, and Goals 2000 (Eisner, 2001, in Flinders \&Thornton, 2009, p. 327; Sleeter \& Stillman, 2005, in Flinders \&Thornton, 2009, pp. 305-306; Darling-Hammond \& McCloskey, 2008, in Ornstein, Pajak \& Ornstein, 2011, p. 336).

The Common Core State Standards is a core curriculum that seeks to ensure that all students, regardless of their circumstance, receive a content-rich education in the full range of the liberal arts and sciences, including English, mathematics, history, the arts, science, and foreign languages. The Common Core State Standards framework comprises six instructional shifts, namely, balancing informational and literary texts for Pre-K-5, and for grades 6-12, knowledge in the disciplines, staircase of complexity, text-based answers, writing from sources, and academic vocabulary (EngageNY, 2012).

\section{Trends in Curriculum Development}

The Common Core State Standards is one of the many curriculum innovations in the history of American education and is not immune to the harsh scrutiny that those before it suffered. As the pressure on education from the outside intensifies, Randi Weingarten, President of the American Federation of Teachers (AFT), has noted that "Public education has been subjected to countless reforms that were undermined by hasty, inadequate implementation" (2016, p. 1). On the same note, Wraga (1999) opined 
that "Politicians have encoded national education goals and subobjectives into federal law and have touted the 'voluntary' adoption of national standards and assessments by state and local education agencies" (p.4). Consequently, every state's department of education has the burden of formulating its education standards, which accounts for the differences in what constitutes the curriculum standards of each state, resulting in the educational issues in the country (Eisner, 2001, in Flinders \& Thornton, 2009, p. 327).

Studies have shown that despite the issues and challenges associated with the Common Core State Standards, states and school districts are doing all they can to make it work (Phillips \& Vandal, 2011). Recent studies show that opinions about the curriculum vary across the authorizing community of educational stakeholderspoliticians, school boards and policymakers, teachers, students, and parents. McMurrer and Frizzell (2013) of the Center on Education Policy (CEP) reported that with a stronger emphasis on college and career readiness for all students, the Common Core Learning Standards demand a better partnership between K-12 education systems and postsecondary education institutions in the adopting states. Whereas the study focused on the administration and implementation of the Common Core State Standards, qualitative research by Ballard, K. \& Bates, A. (2008) focused on a broad examination of the perceptions of the complex mix of factors involved in the implementation of the new curriculum. The importance and significance of this study derive from its suggestion that student achievement is not solely determined by teacher-related factors, but by a complicated nexus of other factors.

Therefore, a common core curriculum that demands content and performance standards would be a significant departure from the existing policy and practice that 
provide differentiated curricula commensurate with the diversity of students' abilities and interests (McPartland, \& Schneider, 1996, p. 66). City, et al. (2009) noted that "Making meaningful and productive changes in instructional practices requires us to confront how they upset and, in some sense, reprogram our past ways of doing things" (p. 22).

\section{Implementation/Teaching Concerns}

Learning is driven by what happens in the classroom between the teacher and the students. If teachers effectively manage other complex factors and demanding situations that exist in the classroom, standards can be raised (Black \& William, 1998). Knowing students' progress and difficulties would help teachers in adapting their work to meet students' needs. They can know students' progress and difficulties through a variety of ways such as observations, class discussions, and reading students' work (Black\& William, 1998; see also Troia \& Olinghouse, 2013).

\section{Testing and Evaluation Concerns}

Although No Child Left Behind legislation passed in 2001 aimed and reinforced achievement with test-based accountability as a means of raising achievement, yet the nation has fallen further behind on international assessments of student learning (DarlingHammond \& McCloskey, 2008, in Ornstein, Pajak, \& Ornstein, 2011, p. 337). Under the standards-based accountability system, subjects outside the core (those that are not tested) are likely to be undermined (Siskin, 2003, in Flinders \& Thornton, 2009, pp. 318-319). 'U. S. teachers have suffered mightily throughout the nation's new policies, and they resent it" (Hargreaves \& Shirley, 2008, in Ornstein, Pajak, \& Ornstein, 2011, p. 319). 


\section{Methodology}

Introduction

In this research, I used a non-experimental quantitative survey approach to examine teachers' implementation of and stages of concern regarding English Language Arts (ELA) Common Core State Standards (CCSS) in New York State. Statistical analyses of data involved descriptive and correlational analyses. Results are summarized in Tables.

\section{Research Questions}

Accordingly, the study was explored the following research questions:

1. To what extent do teachers implement the Common Core State Standards?

2. Is the extent of implementation related to school level (middle vs. high school) and years of implementing common core standards?

3. What concerns do New York State English Language Arts teachers have regarding the implementation of the Common Core State Standards (CCSS) and at what stages are their concerns?

4. What relationships exist between teachers' Stages of Concern and their extent of implementation of the Common Core State Standards?

\section{Research Design}

This research is a non-experimental quantitative survey study of fifty-three public school Grades 6-12 ELA teachers in New York State. Because of its versatility, efficiency, and generalizability, survey research is commonly used in education (Schutt, 1996, as cited in McMillan and Schumacher 2010, P. 236). 


\section{Population and sample}

This study's population comprised of Grades 6-12 English Language Arts teachers in the New York State Public School system. This study utilized a nonprobability sampling approach called purposive sampling. This sampling technique involves the selection of a group of individuals known as samples from the population or the whole group to which results can be generalized. Accordingly, a purposeful sample of fifty-three Grades 6-12 English Language Arts public school teachers, tenured and nontenured, who have one or more years of Common Core State Standards implementation experience participated in this study.

\section{Instrumentation}

Stages of Concern. Teachers' Stages of Concern regarding the Common Core State Standards were studied quantitatively with the Stages of Concern Questionnaire (SoCQ). SoCQ is an electronic survey instrument. I used a seven-path Stages of Concern (SoC) questionnaire comprising of 35 focused items.

Extent of Implementation. I designed the extent of implementation questionnaire specifically for this study using the Common Core State Standards.

\section{Reliability and Validity}

To ensure the reliability and the validity of the instruments, I pilottested both the modified Stages of Concern Questionnaire (SoCQ) and the Extent of Implementation Questionnaire with a sample representative of the target population. Experts judges in the field, Jimmy Kijai, Ph.D., Grace Nwosu, Ph.D., and Larry Burton, Ph.D., scrutinized the instruments and 
offered recommendations. I modified them accordingly and resubmitted them for their approval before I administered them.

\section{Procedures}

I ensured the protection of participants from psychological risks and guaranteed confidentiality in all phases of this study. I obtained and disclosed to participants IRB approvals from Andrews University and New York City Board of Education to administer a modified Stages of Concern Questionnaire (SoCQ) as well as the Extent of Implementation Questionnaire to participants. In doing this, I complied with the requirement that participants should be adequately informed about the study even though participation through questionnaires and surveys does not require physical interaction with participants (Portney \& Watkins, 2000, p. 312).

I administered the surveys together electronically using the SurveyMonkey platform. I used Emails, newspaper advertisements, and postcards with a link to the questionnaires to promote participation in the study.

\section{Data Analysis}

1. To what extent do teachers implement the Common Core State Standards? Descriptive statistics (mean, standard deviation and frequency) were used to determine the extent of implementation of the common core standards. For interpretation purpose, raw scores of 1(never) and 2(monthly) are considered inadequate; scores of 3(once biweekly), 4(once a week) and 5 (2-3 a week) are considered moderately adequate; and 6(once a day), 7(2-3 times a day) and 8 (more than 3 times a day) are considered adequate. 
2. Is the extent of implementation related to school level (middle vs. high school) and years of implementing common core standards? Independent samples t-test was used to compare middle and high school teachers' levels of implementations. Spearman rho correlation was used to determine the relationship between levels of implementation and years of experience implementing the common core standards. Teachers indicated their years of experience in categories (ordinal).

3. What concerns do New York State English Language Arts teachers have regarding the implementation of the Common Core State Standards (CCSS) and at what stages are their concerns? Frequency distributions were used to determine the stage of concerns with teachers' implementation of the common core standards.

4. What relationships exist between teachers' Stages of Concern and their extent of implementation of the Common Core State Standards? Spearman rho correlation coefficients were used to determine relationship between implementation and stage of concerns. Stages of concerns are assumed to be ordinal.

\section{Summary of Key Findings}

New York State's Grade 6 -12 public school teachers in this study implemented 13 of the 15 English Language Arts (ELA) Common Core State Standards (CCSS) at least once a week $(M=4.02$ to $M=6.15)$. Overall, levels of implementation of the 15 CCSS ranged from moderately adequate, low mean $3.22(\mathrm{SD}=1.43)$ to adequate, a high mean of 6.15 ( $\mathrm{SD}=1.36)$. Teachers seem to selectively implement the standards. Levels of implementation were similar in both middle and high schools ( $\mathrm{p}>.05)$ and appeared to be unrelated to number of years implementing the CCSS. Approximately half (52.8\%) of 
the participants were at concern stages 4 to 6 . Overall, there was no relationship between Stage of Concern and levels of implementation of the CCSS.

\section{Discussion of Key Findings}

Research Question One

To what extent do teachers implement the Common Core State Standards?

Reading. The finding that approximately $77 \%$ to $98 \%$ of teachers were

moderately adequate or adequately implementing the reading core standards. This finding is important for several reasons. First, it is important given the emphasis on reading in the Common Core Instructional Shifts. Four of the five shifts focus on activities that help students to developing reading competencies in reading a variety of complex informational and literary texts and to develop knowledge in various disciplines to "engage in rich and rigorous evidence based conversations about text" (EngageNY, 2012).

Second, this finding is important because several reading standards-related skills are tested in the Common Core assessments. As noted in the New York City Department of Education website (https://www.schools.nyc.gov) regarding ELA assessment for both middle and high school,

The ELA test is an untimed test that contains several different kinds of questions. Students answer multiple-choice questions based on short passages they read, and write responses to open-ended questions based on stories, articles, or poems they listen to or read. (NYCDE)

The Common Core-aligned Regents examinations often have reading comprehension passages and written response questions that require students to demonstrate mastery in reading and analyzing parallel texts to determine common themes 
or claims. Students are always required to demonstrate the ability of these skills in responding to the argument essay question. For example, in the Regents High School Examination of Monday, January 22, 2018, Part 2, Argument, the following prompt was given:

Directions: Closely read each of the four texts provided on pages 11 through 17 and write a source-based argument on the topic below.... [emphasis added] Topic: Could algae be the solution to our energy problems? Your Task: Carefully read each of the four texts provided [emphasis added]. Then, using evidence from at least three of the texts, write a welldeveloped argument regarding whether or not algae could be the solution to our energy problems [emphasis added]. Clearly establish your claim, distinguish your claim from alternate or opposing claims, and use specific, relevant, and sufficient evidence from at least three of the texts to develop your argument. Do not simply summarize each text. (OSA, 2020, p. 10)

Third, this relatively high level of reading standards implementation is important because reading is a foundational skill for academic success. Walpole \& McKennna (2004) have noted that failure to establish early literacy competence has long-term academic consequences (p. 163).

Writing. In writing, most teachers were adequately implementing activities in two areas: activities requiring students to produce clear and coherent writing (62.3\%) and developing and strengthening the writing process (54.8\%). These findings are important for two reasons. One, these findings suggest that teachers might be selectively emphasizing and teaching the standards. The two most implemented standards above are 
geared more toward Common Core and Regents assessments and instructional shift 5:

"Writing emphasizes use of evidence from sources to inform or make an argument" (EngageNY, 2012). George (2015) found,

the majority of the teachers felt that the use of state/district standardized testing pressured them to teach standards and content that are on the state/district test, to eliminate curriculum materials that are not tested, to spend a lot of time on testtaking skills, and on rote drill in teaching, to emphasize factual recall knowledge, and to use explicit instruction, clarify learning goals, and be more effective teachers to students who struggle academically. (p. 87)

The Common Core-aligned Regents examinations often have argument essay (see the previous example) and text analysis response questions that echo instructional shift 5 and the two standards most teachers are implementing (EngageNy, 2012). For instance, in the Regents High School Examination of Tuesday, January 21, 2020, Part 3, TextAnalysis Response, the following prompt was given:

Part 3

\section{Text-Analysis Response}

Your Task: Closely read the text provided on pages 22 and 23 and write $a$ welldeveloped, text-based response of two to three paragraphs [emphasis added]. In your response, identify a central idea in the text and analyze how the author's use of one writing strategy (literary element or literary technique or rhetorical device) develops this central idea [emphasis added]. Use strong and thorough evidence from the text to support your analysis [emphasis added]. Do not simply summarize the text. You may use the margins to take notes as you read and scrap paper to plan your response. Write your response in the spaces provided on pages 7 through 9 of your essay booklet. 


\section{Guidelines:}

Be sure to:

- Identify a central idea in the text

- Analyze how the author's use of one writing strategy (literary element or literary technique or rhetorical device) develops this central idea. Examples include: characterization, conflict, denotation/connotation, metaphor, simile, irony, language use, point-of-view, setting, structure, symbolism, theme, tone, etc.

- Use strong and thorough evidence from the text to support your analysis

- Organize your ideas in a cohesive and coherent manner

- Maintain a formal style of writing

- Follow the conventions of standard written English (OSA, 2020, p. 21)

A writing task of this nature and context requires the two skills most teachers are implementing. More than half of the teachers were inadequately performing activities that help students to develop real or imagined experience or events' (56.6\%), to 'gather relevant information from multiple print and digital sources and integrate the information while avoiding plagiarism' (52.8\%); and to 'conduct short and sustained research projects' (67.9\%). These standards are not explicitly emphasized in the Common Core Instructional Shifts (EngageNY, 2012) and are not tested in the Regents exam.

Therefore, the selective implementation of the writing standards is an important finding considering that colleges want entering students to come in having mastered these the least implemented writing standards. According to Butrymowicz (2017), "The vast majority of public two- and four-year colleges report enrolling students - more than half a million of them-who are not ready for college-level work." Selective implementation of the standards may cause students to spend more time and money in college. "A gap in skill level is often met with remedial English courses in the first semester of college" (Center for Online Education, 2019). 
Speaking and Listening. The speaking and listening standards, like the reading and writings standards, were also selective implemented. Over $90 \%$ of the teachers moderately adequately and adequately implemented 'activities that required students to prepare for and participate effectively in a range of conversations and collaborations with diverse partners.' Although this standard is not directly tested in the Common Core assessments, this high percentage is not surprising considering that many school districts are emphasizing group work and problem-based learning, and collaboration, all of which requires the skills incorporated in this standard. In my school district, it is mandatory for students to seat in groups of four and they are expected to engaging in task-oriented conversations while work collaboratively. Additionally, these skills are explicitly stated in Instructional Shift 4: "Students engage in rich and rigorous evidence based conversations about text" (EngageNY, 2012). This shows that teachers are more likely to tailor their teaching to meet certain accountability expectations.

Language. More than $50 \%$ of the teachers adequately implemented all items of the language core standards. The best implemented standard is to 'acquire and use accurately a range of general academic and domain-specific words and phrases'. Again, this finding follows teachers' pattern of teaching in alignment with the Common Core Instructional Shifts 2 (EngageNY, 2012) and the Common Core standardized assessments. This is an essential skill that cuts across reading, writing, and speaking and listening, as well as CCSS assessments.

In all, the findings regarding the extent to which teachers are implementing the CCSS beg the question, why do teachers selectively apply them? As noted earlier, the rationalization approach to curriculum has some negative consequences. It leads schools 
to narrow the content and focus on teaching to the test (Eisner, 2001, in Flinders \& Thornton, 2009, pp. 329-330), a practice that raises issues of equity and excellence in education. Walpole and McKenna (2004) opined that "Standardized testing is a burden most teachers bear resentfully. Such testing often has an undue influence on planning. It is a source of anxiety and frustration for teachers and administrators alike" (p. 77). The politics and the punitive accountability measures that are associated with students' tests scores cause enough anxiety to compel teachers to selectively implement the curriculum. However, teachers are doing their best to implement the curriculum. Amore, et al. (2015) in their study of teacher leadership in relationship to the Common Core success concluded that,

With all of the political posturing, it's easy to lose focus and pay little heed to the voices of the people most affected by the standards - teachers and students. States and districts face serious challenges as they continue the transition to the Common Core, and some places are experiencing more success than others. Yet while the Common Core may continue to be litigated in state houses throughout the country and while national politicians may use it as a political wedge, teachers are hard at work implementing the standards each day. As such, teachers' voices on Common Core implementation are vitally important to its success. (p.1)

\section{Research Question Three}

What concerns do New York State English Language Arts Teachers have regarding the implementation of the Common Core State Standards (CCSS), and at what stages are their concerns?

The Concerns-Based Adoption Model (CBAM) Stages of Concern Questionnaire is more or less a diagnostic tool. These Stages of Concern data, rather than implying teachers' ineffectiveness in implementing the curriculum reveal significant gaps between where the teachers were and where they ought to be. It is used to detect and determine 
how individuals in an innovation process learning and stages of their development, and the stages to which individuals identify with are not for making a comparative value judgment about them. The authors strongly recommend limiting their use for diagnostic purposes for personnel directly involved in the process of an innovation adoption or production (George, et al. 2013, p.55).

A frequently asked question about the Stages of Concern data, noted Hall and Hord (2011), is if an individual can have concerns at more than one stage at the same time. They said that it is possible and that most of the time, an individual's intense concerns can be at more than one stage. In general, they further explained, teachers had "a conglomeration of concerns representing several of the stages, with some more strongly felt than others and some absent altogether" (p. 75).

I also took into account that the authors further noted that concerns are inappropriately analyzed when viewed in terms of good or bad, which they are not. Belonging to the different stages does not compare individuals in terms of being better than the other, but rather an indication of the differences in the assistance they need with the innovation (George et al. 2013, p.55). So, with the Stages of Concerns data obtained, teachers' needs were diagnosed, and conclusions about them were made.

To determine the several stages that represent teachers' conglomeration of concerns, I conducted a descriptive analysis of the data. Table 14 shows that approximately 50 percent of the teachers are in Stages 4 through 6. These teachers are concerned about how the implementation of the core standards impact their students and that they may have better ideas for implementing the curriculum or changing it altogether. 
Concern Stage 4 is the first of the three impact stages of the Concerns-Based Adoption Model (CBAM). Teachers in this stage focus more on reflecting on the impact of CCSS on students in their immediate sphere of influence. All Stage 4 concerns, to some extent, were true of the eleven teachers in this stage.

When we imagine the potential practical impact of the hasty adoption of the curriculum and the threatening consequences of underperformance measured by students' test scores, having $21 \%$ of teachers in this stage is commendable within the first three to four years of adopting the CSSS, irrespective of the selectiveness in the implementation of the curriculum. Darling Hammond \& McLaughlin (1995) noted that "Teachers learn by doing, reading, and reflecting....” (p. 598, in Blintz, 2007, p. 204). This data suggests that when teachers are adequately prepared for the adoption of a new curriculum and are provided targeted professional development opportunities, more of them would move up to higher stages of concern. All teachers ought to be reflective practitioners as required in the Danielson's Framework for Teaching (Danielson, 2013, see Appendix C).

Concern Stage 5 is the second of the three CBAM impact stages. The $22.6 \%$ of teachers in this study who were in this stage focus on how to coordinate and collaborate with their colleagues in implementing the CCSS. As we all know, collaboration is at the heart of professional development and a successful implementation of any innovation. This finding is important and makes a case against inadequate collaboration among teachers in implementing the curriculum. The data show that, in all cases $26.4 \%$ of the participants were not concerned or did not care about collaborating with other faculty members in implementing the curriculum. Collaboration is a highly valued professional practice enshrined in Domain 4 of Danielson's framework (Danielson, 2013, see 
Appendix C). Overemphasis on the standards and a hasty adoption process could lead to overlooking effective curriculum and professional development for teachers (Main, 2012, p. 73; see also McPartland \& Schneider).

Also, the high-stakes assessment component of the Common Core State Standards could be responsible for the lack of teachers' interest in collaboration detected in this study. As noted earlier, "High-stakes, test-driven assessment inhibits collaboration among educators, hinders student engagement, and undermines critical thinking" (Barlowe \& Cook, 2016, p. 6). The moderate concern for collaboration could be related to the Stage 3 Concerns in Table 18, where one-half of the teachers expressed concern about inadequate time to organize themselves each day. The collaboration would be difficult if teachers don't have enough time even to stay organized daily. Amore, et al. (2015) found that Teachers identified professional development as an important element in Common Core implementation (p. 2).

Concern Stage 6 is the third and highest of the impact stages of the CBAM. The $11.3 \%$ of teachers in this stage focus on exploring ways to reap more universal benefits from the CCSS, making significant changes to it, or replacing it with a more robust alternative. If the Stages of Concern data were to be used in determining good and bad teachers, the teachers in this stage would be described as the good ones. All Stage 6 teachers appear to have more understanding of the Common Core curriculum. They were refocusing - exploring ways to other ways to reap more universal benefits from the curriculum, make major changes to it, or replace it with a more robust alternative. This finding is important for at least two reasons. One, if this finding is representative of what is happening in the general population, then these teachers could be recruited as 
instructional coaches, facilitators, and mentors to teachers in nonimpact stages state-wide, and that would make the achievement of the goals of Every Student Succeeds Act (ESSA) easily achievable.

Second, when we consider the rushed adoption and implementation of the CCSS and the political climate surrounding it from its inception to the present, this finding suggests that teachers are doing all they can to learn about the curriculum and to transform teaching and learning. According to Martin (2015),

The truth is that Common Core implementation varies dramatically in schools and districts across the country. Some districts and schools made missteps during the transition by moving too quickly, not providing the necessary training and support, or failing to communicate with parents about what to expect and why it matters. Yet other schools have managed an almost seamless transition that has energized teachers and transformed teaching and learning.

\section{Implications for Practice}

The varying levels of implementation of the Common Core State Standards (CCSS) indicate that teachers are selectively implementing the standards they knew were mostly tested and leaving out the least tested (Tables 4-8). This presumed selective approach to implementation of the standards could be related to the strict accountability measures attached to the curriculum.

First, the Every Student Succeeds Act (ESSA) mandates providing an equitable opportunity for academic success to all students, irrespective of their backgrounds (nysed.org). Students whose teachers neglect specific standards would end up lacking abilities in those areas. Case in point, with the outbreak of the Corona Virus (COVID19), schools across America are struggling with the urgent need to provide remote education and to get their students to adapt to it. Many students, especially those in poor 
districts, are unable to participate in remote learning because they lack the skills to work in the online environment.

Second, the inadequate or selective implementation of the curriculum standards could predictably result in inadequately prepared high school students who lack the skills they need to be successful in college. Poorly prepared students spend more on failed courses or in taking remedial courses or may even drop out of college. If this trend continues, the Every Student Succeeds Act would be another failed legislation.

According to Ostashevsky (2016), “The number of students passing exit tests and graduating from high school is at an all-time high, but nearly 60 percent of students in community colleges need remedial courses before they can take college-level classes." Similarly, Sarah Butrymowicz (2017), in Hechinger Report (a national nonprofit newsroom that reports on only education), noted that most schools place students in remedial courses in math or English before they can move on to a full load of collegelevel, credit-bearing courses. This process is a financial drain on not only students but also colleges and taxpayers, costing up to an estimated $\$ 7$ billion a year. What is concerning about this picture is that the enrollment in the remedial courses does not guarantee college graduation. "Students who enroll in these remedial courses often never even make it into the classes that will count toward a degree" (Butrymowicz, 2017).

Another Hechinger Report writer, Luba Ostashevsky (2016), noted that colleges even consider students who have passed state tests inadequate for college-level work, and this may come to students and their parents as news. This challenge has forced teachers to teach to the test at the expense of the critical skills students need for college work. These inadequacies have implications for students of color in many New York State low- 
income school districts where the failure and dropout rates are already high. Santelises (2016) has noted that

students of color and low-income students had considerably lower rates of mastery than their peers, with the starkest difference among graduates who had completed a college-ready curriculum: 82 percent of white graduates had a 2.5 GPA or higher in their academic courses, compared with just 51 percent of black graduates and 63 percent of Latino graduates.

In all, this study's findings represent a preliminary road map to broader studies on teachers' implementation of and stages of concern regarding English Language Arts (ELA) Common Core State Standards (CCSS) in New York State. The Common Core is a recent reform with no studies on teacher's stages of concern and the extent to which they are implementing them. Teachers' and administrators' implementation of any curriculum requires ongoing reflections to help them understand deeply the innovation and their implementation processes. Blintz (2007) in a study on how learning is evaluated and assessed found that teachers' stories can challenge us to "think more broadly and more deeply about curriculum and curriculum development. They also have reminded us that creating challenging and meaningful curriculum is very thoughtful work" (p. 223).

Third, identifying the precise location of teachers on the Stages of Concern framework and attending to their concerns are critical for developing and sustaining a non-selective implementation of a new curriculum. Providing teachers and administrators adequate time for professional development, common planning, and collaboration to understand a new curriculum before they start implementing it would likely increase the number of teachers at the highest impact stage levels.

To do so requires strong leadership to organize teachers around a clear goal and to develop a shared mission and a uniform implementation culture. According to City et al. 
(2009), an investment in teacher professional development without a clear goal and student performance expectations results in random implementation across classrooms. Consequently, it results in no system-wide or school-wide impact on student learning (p.25).

Targeted and ongoing professional development for teachers and administrators is necessary to learn enough about a new curriculum before and during implementation. Elizabeth City et al. (2009) opined, a failure to attend to teachers' professional development and skill as part of the improvement strategy results in low-level teaching of high-level content. This phenomenon is commonplace in American classrooms (p.25). "Asking people to reflect on their perceptions prior to beginning the reform process involves them early on, gives them the message that what they think is important, and provides rich data and information for the future" (Johnson, 2002, p. 128).

Fourth, to implement the Common Core State Standards or any new curriculum evenly and equitably, schools should be data-driven. Schools should have a data collection, collation, and analysis protocols in place. According to Johnson (2002), "Processes and practices affect student outcomes, but little time is spent in systematically looking at the everyday workings of the institution. Most of the answers to why outcomes appear as they do are embedded in norms and practices" (p. 127). Johnson further also noted that to address teachers' concerns and curriculum implementation issues effectively, schools need a system for analyzing school indicators such as student characteristics, school characteristics, administrator and teacher characteristics, student outcome information and aspirations, parent involvement, and resources, or the process. "In the adoption and implementation of a new reform initiative, "a coherent system for 
gathering and analyzing indicator data should be developed at the outset of the reform effort, or the process can become fragmented and ineffective" (p.219).

\section{Recommendations for Future Research}

Lessons learned from this study would help in effective planning for the phasing in of the new curriculum, Next Generation, which will replace the Common Core State Standards (CCSS) starting in 2021/2022 school year, or any other curriculum. Based on the findings and their implications, I proffer the following recommendations for future research.

1. Change in Study Design. This study's findings and conclusions, as expected, were limited to the number of accurately completed surveys. Future studies on this subject can conducted regionally or nationally. A longitudinal or a mixed-method (interview and observation) study of this topic would allow for sufficient time to collect and collate a large volume of data to make broader generalizations on the subject.

2. Studies of Professional Development. Focused studies on the relevance, timing, and extent of professional development opportunities teachers are getting when a new curriculum is adopted is necessary. According to Reyes and Lappan (2007), the implementation of a coherent and rigorous curriculum requires leadership, cooperation, and collaboration (as cited in Main, 2012, p. 74). Therefore, studies are needed to determine the extent to which school administrators are involved in curriculum adoption with regards to what monitoring and feedback strategies they are using to ensure that all teachers are collaborating and adequately implementing all components of the curriculum. 


\section{APPENDIX A}

\section{INFORMED CONSENT}

lork State Teachers' Stages $\times \quad 6$ www.commoncorestudy.com $\times 1+$

New York State Teachers' Stages of Concern and Extent of Implementation of English Language Arts Common Core State Standards in the Wake of Every Student Succeeds Act (ESSA)

\section{Informed Consent}

$1 / 18$ $5 \%$

Alozie Ogbonna

School of Education

Department of Curriculum and Instruction

Andrews University

Berrien Springs, Michigan

Teachers across America have many concerns regarding the Common Core State Standards and how to effectively implement them. The high stakes testing involved and the use of test scores from these tests in student, teacher, and school evaluations have sparked a heated debate amongst the various stakeholders of education—parents, students, teachers, school administrators, the public, and politicians alike

This study seeks to understand Grades 6-12 New York State English Language Arts teachers' stages of concern regarding the Common Core State Standards (CCSS) and extent of implementation of the CCSS in the wake of Every Student Succeeds Act (ESSA). You have arrived at this survey website by following the link from the published advertisement for this study. As a result, your participation in the research project will remain completely anonymous. Involvement in this study is voluntary and the only expectation for participants is to complete an electronic survey. The survey should take no longer than 10 minutes to complete. Participants will not be contacted after the completion of the survey

Inclusion/Exclusion: Grades 6-12 English Language Arts teachers, tenured and non-tenured, who have no less than one year of Common Core State Standards implementation experience will be surveyed. Grades 1-5 ELA teachers will not participate. Responses of teachers with less than one year experience and private school teachers will not be included in the study.

The general benefit of this study is that it will help to determine teachers' concerns and problems with implementing the Common Core State Standards. The identification of these concerns and problems will help in determining what types of professional learning experiences teachers need to help them understand the CCSS, how to implement them to increase student achievement, and what resources they need to enhance their teaching.

For questions or more information about this study, I can be reached by email at alozie247@gmail.com, by phone or text message at 917-5157889, and by regular mail at Alozie Ogbonna, 2749 Yates Avenue, Bronx, NY 10469. You may also contact my research advisor, Professor Larry D. Burton, by mail at Teaching, Learning, \& Curriculum Department, 4195 Administration Drive, Berrien Springs, MI, 49104-0101, and by email burton@andrews.edu, or by phone or text message at 269-519-8733. Your completion of this electronic survey serves as a form of implied consent to participate in this research. That means that you have read the information on this screen, understood the information presented, and choose to participate in the study. You understand that participation is voluntary and you may withdraw from the study at any time by exiting the survey before its completion. Please click the "Next" to continue with the survey. 


\section{APPENDIX B}

\section{SURVEY INSTRUMENTS}

\section{EXTENT OF IMPLEMENTATION}

New York State Teachers' Stages of Concern and Extent of Implementation of English Language Arts Common Core State Standards in the Wake of Every Student Succeeds Act (ESSA)

\section{COLLEGE AND CAREER READINESS ANCHOR STANDARDS FOR READING}

$2 / 19$ $11 \%$

KEY IDEA S AND DETAILS (KID)

1. I implement activities that require students to

$$
\begin{array}{cc}
\text { Once Every } & \begin{array}{c}
\text { Once Every } \\
\text { Second Week } \\
\text { Month Across }
\end{array} \\
\text { Across All } \\
\text { All Classes | } & \text { Classes | }
\end{array}
$$

Once Weekly Across All

Classes I

2-3Times Weekly Acros

All Classes

Once Daily
Across All

Across All

More than 3

Teach Teach

Teach

Teach

Across Al

Classes I

Teach

More than 3 times per day

read closely to determine

what the text says

explicitly and to make

logical inferences from it,

and cite specific textual

evidence.

determine central ideas or

themes of a text and

analyze their

development; summarize

the key supporting details and ideas.

analyze how and why

individuals, events, and

ideas develop and interact over the course of a text.

Never


New York State Teachers' Stages of Concern and Extent of Implementation of English Language Arts Common Core State Standards in the Wake of Every Student Succeeds Act (ESSA)

\section{COLLEGE AND CAREER READINESS ANCHOR STANDARDS FOR READING}

$3 / 18$ $16 \%$

\section{CRAFT AND STRUCTURE (CS) \& INTEGRATION OF KNOWLEDGE AND IDEAS (IKI)}

2. (CS) I implement activities that require students to

\begin{tabular}{|c|c|c|c|c|c|c|c|c|}
\hline & Never & $\begin{array}{c}\text { Once Every } \\
\text { Month Across } \\
\text { All Classes I } \\
\text { Teach }\end{array}$ & $\begin{array}{c}\text { Once Every } \\
\text { Second Week } \\
\text { Across All } \\
\text { Classes I } \\
\text { Teach }\end{array}$ & $\begin{array}{c}\text { Once Weekly } \\
\text { Across All } \\
\text { Classes I } \\
\text { Teach }\end{array}$ & $\begin{array}{c}\text { 2-3Times } \\
\text { Weekly Across } \\
\text { All Classes I } \\
\text { Teach }\end{array}$ & $\begin{array}{c}\text { Once Daily } \\
\text { Across All } \\
\text { Classes I } \\
\text { Teach }\end{array}$ & $\begin{array}{l}\text { 2-3 Times Daily } \\
\text { Across All } \\
\text { Classes I } \\
\text { Teach }\end{array}$ & $\begin{array}{c}\text { More than } 3 \\
\text { Times Daily } \\
\text { Across All } \\
\text { Classes I } \\
\text { Teach }\end{array}$ \\
\hline $\begin{array}{l}\text { interpret words and } \\
\text { phrases as they are used } \\
\text { in a text, and how specific } \\
\text { word choices shape } \\
\text { meaning or tone. }\end{array}$ & & & & & & & & \\
\hline $\begin{array}{l}\text { analyze the structure of } \\
\text { texts, including how } \\
\text { specific sentences, } \\
\text { paragraphs, and larger } \\
\text { portions of the text relate } \\
\text { to each other and the } \\
\text { whole. }\end{array}$ & & & & & & & & \\
\hline $\begin{array}{l}\text { assess how point of view } \\
\text { or purpose shapes the } \\
\text { content and style of a text. }\end{array}$ & & & & & & & & \\
\hline
\end{tabular}

3. (IKI) I implement activities that require students to

\begin{tabular}{|c|c|c|c|c|c|c|c|c|}
\hline & Never & $\begin{array}{c}\text { Once Every } \\
\text { Month Across } \\
\text { All Classes I } \\
\text { Teach }\end{array}$ & $\begin{array}{c}\text { Once Every } \\
\text { Second Week } \\
\text { Across All } \\
\text { Classes I } \\
\text { Teach }\end{array}$ & $\begin{array}{c}\text { Once Weekly } \\
\text { Across All } \\
\text { Classes I } \\
\text { Teach }\end{array}$ & $\begin{array}{c}\text { 2-3Times } \\
\text { Weekly Across } \\
\text { All Classes I } \\
\text { Teach }\end{array}$ & $\begin{array}{l}\text { Once Daily } \\
\text { Across All } \\
\text { Classes I } \\
\text { Teach }\end{array}$ & $\begin{array}{c}\text { 2-3 Times Daily } \\
\text { Across All } \\
\text { Classes I } \\
\text { Teach }\end{array}$ & $\begin{array}{c}\text { More than } 3 \\
\text { Times Daily } \\
\text { Across All } \\
\text { Classes I } \\
\text { Teach }\end{array}$ \\
\hline $\begin{array}{l}\text { integrate and evaluate } \\
\text { content presented in } \\
\text { diverse formats and } \\
\text { media... }\end{array}$ & & & & & & & & \\
\hline $\begin{array}{l}\text { delineate and evaluate the } \\
\text { argument and specific } \\
\text { claims in a text. }\end{array}$ & & & & & & & & \\
\hline $\begin{array}{l}\text { analyze how two or more } \\
\text { texts address similar } \\
\text { themes or topics. }\end{array}$ & & & & & & & & \\
\hline
\end{tabular}

Prev Next

Powered by

SurveyMonkey 
New York State Teachers' Stages of Concern and Extent of Implementation of English Language Arts Common Core State Standards in the Wake of Every Student Succeeds Act (ESSA)

\section{COLLEGE AND CAREER READINESS ANCHOR STANDARDS FOR READING}

$4 / 19$ $21 \%$

RANGE OF READING AND LEVEL OF TEXT COMPLEXITY (RLTC) \& RESPONSE TO LITERATURE (RL)

4. (RLTC) I implement activities that require students to

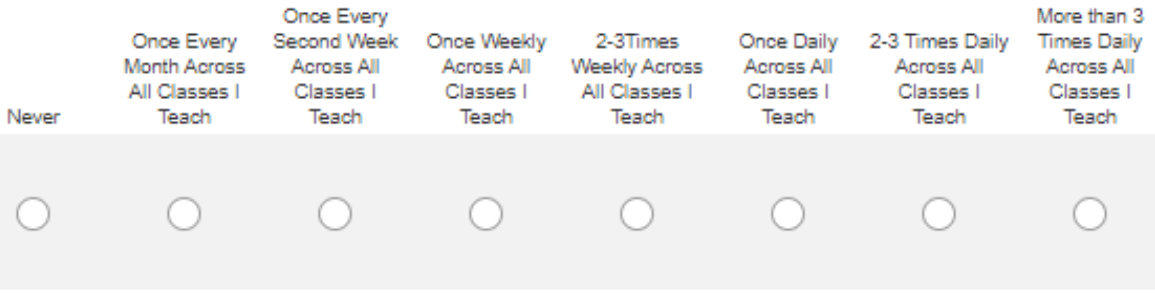

5. (RL) I implement activities that require students to

read and comprehend complex literary and

informational texts

independently and

proficiently.

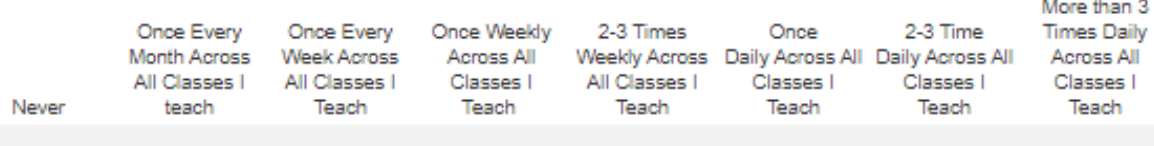

respond to literature by

employing knowledge of

literary language, textual

features, and forms.

Teach

$\bigcirc$ 
New York State Teachers' Stages of Concern and Extent of Implementation of English Language Arts Common Core State Standards in the Wake of Every Student Succeeds Act (ESSA)

5. COLLEGE AND CAREER READINESS ANCHOR STANDARDS FOR WRITING

$5 / 19$

\section{TEXT TYPES AND PURPOSE (W-TTP) \& PRODUCTION AND DISTRIBUTION OF WRITING (W-PDW)}

6. (W-TTP) I implement activities that require students to

\begin{tabular}{|c|c|c|c|c|c|c|c|c|}
\hline & Never & $\begin{array}{c}\text { Once Every } \\
\text { Month Across } \\
\text { All Classes I } \\
\text { Teach }\end{array}$ & $\begin{array}{l}\text { Once Every } \\
\text { Second Week } \\
\text { Across All } \\
\text { Classes I } \\
\text { Teach }\end{array}$ & $\begin{array}{c}\text { Once Weekly } \\
\text { Across All } \\
\text { Classes I } \\
\text { Teach }\end{array}$ & $\begin{array}{c}\text { 2-3Times } \\
\text { Weekdy Across } \\
\text { All Classes I } \\
\text { Teach }\end{array}$ & $\begin{array}{c}\text { Once Daily } \\
\text { Across All } \\
\text { Classes I } \\
\text { Teach }\end{array}$ & $\begin{array}{c}\text { 2-3 Times Daily } \\
\text { Across All } \\
\text { Classes I } \\
\text { Teach }\end{array}$ & $\begin{array}{c}\text { More than } 3 \\
\text { Times Daily } \\
\text { Across All } \\
\text { Classes I } \\
\text { Teach }\end{array}$ \\
\hline $\begin{array}{l}\text { to write arguments to } \\
\text { support claims in an } \\
\text { analysis of topics or texts, } \\
\text { using valid reasoning and } \\
\text { relevant and sufficient } \\
\text { evidence }\end{array}$ & & & & & & & & \\
\hline $\begin{array}{l}\text { write } \\
\text { informative/explanatory } \\
\text { texts to examine and } \\
\text { convey complex ideas and } \\
\text { information clearly and } \\
\text { accurately. }\end{array}$ & & & & & & & & \\
\hline $\begin{array}{l}\text { write narratives to develop } \\
\text { real or imagined } \\
\text { experiences or events. }\end{array}$ & & & & & & & & \\
\hline
\end{tabular}

7. (W-PDW) I implement activities that require students to

\begin{tabular}{|c|c|c|c|c|c|c|c|c|}
\hline & Never & $\begin{array}{c}\text { Once Every } \\
\text { Month Across } \\
\text { All Classes I } \\
\text { Teach }\end{array}$ & $\begin{array}{l}\text { Once Every } \\
\text { Second Week } \\
\text { Across All } \\
\text { Classes I } \\
\text { Teach }\end{array}$ & $\begin{array}{c}\text { Once Weekly } \\
\text { Across All } \\
\text { Classes I } \\
\text { Teach }\end{array}$ & $\begin{array}{c}\text { 2-3 Times } \\
\text { Weekly Across } \\
\text { All Classes I } \\
\text { Teach }\end{array}$ & $\begin{array}{c}\text { Once Daily } \\
\text { Across All } \\
\text { Classes I } \\
\text { Teach }\end{array}$ & $\begin{array}{c}\text { 2-3 Times } \\
\text { Daily Across All } \\
\text { Classes I } \\
\text { Teach }\end{array}$ & $\begin{array}{l}\text { More than } 3 \\
\text { times Daily } \\
\text { Across All } \\
\text { Classes I } \\
\text { Teach }\end{array}$ \\
\hline $\begin{array}{l}\text { produce clear and } \\
\text { coherent writing }\end{array}$ & & & & & & & & \\
\hline $\begin{array}{l}\text { develop and strengthen } \\
\text { writing process }\end{array}$ & & & & & & & & \\
\hline $\begin{array}{l}\text { use technology to produce } \\
\text { and publish writing and to } \\
\text { interact and collaborate } \\
\text { with others. }\end{array}$ & & & & & & & & \\
\hline
\end{tabular}


New York State Teachers' Stages of Concern and Extent of Implementation of English Language Arts Common Core State Standards in the Wake of Every Student Succeeds Act (ESSA)

\section{COLLEGE AND CAREER READINESS ANCHOR STANDAR FOR WRITING}

$6 / 19$ $32 \%$

\section{RESEARCH TO BUILD AND PRESENT KNOWLEDGE (W-RBPK), RANGE OF WRITING (W-RW), AND RESPONDING TO LITERATURE (W-RL)}

8. (R-RBPK) I implement activities that require students to

\begin{tabular}{|c|c|c|c|c|c|c|c|c|}
\hline & Never & $\begin{array}{c}\text { Once Every } \\
\text { Month Across } \\
\text { All Classes I } \\
\text { Teach }\end{array}$ & $\begin{array}{l}\text { Once Every } \\
\text { Second Week } \\
\text { Across All } \\
\text { Classes I } \\
\text { Teach }\end{array}$ & $\begin{array}{l}\text { Once Weekly } \\
\text { Across All } \\
\text { Classes I } \\
\text { Teach }\end{array}$ & $\begin{array}{c}\text { 2-3Times } \\
\text { Weekly Across } \\
\text { All Classes I } \\
\text { Teach }\end{array}$ & $\begin{array}{l}\text { Once Daily } \\
\text { Across All } \\
\text { Classes I } \\
\text { Teach }\end{array}$ & $\begin{array}{c}\text { 2-3 Times Daily } \\
\text { Across All } \\
\text { Classes I } \\
\text { Teach }\end{array}$ & $\begin{array}{c}\text { More than } 3 \\
\text { Times Daily } \\
\text { Across All } \\
\text { Classes I } \\
\text { Teach }\end{array}$ \\
\hline $\begin{array}{l}\text { conduct short as well as } \\
\text { more sustained research } \\
\text { projects based on focused } \\
\text { questions. }\end{array}$ & & & & & & & & \\
\hline $\begin{array}{l}\text { gather relevant information } \\
\text { from multiple print and } \\
\text { digital sources, and } \\
\text { integrate the information } \\
\text { while avoiding plagiarism. }\end{array}$ & & & & & & & & \\
\hline $\begin{array}{l}\text { draw evidence from } \\
\text { literary or informational } \\
\text { texts to support analysis, } \\
\text { reflection, and research. }\end{array}$ & & & & & & & & \\
\hline
\end{tabular}

9. (W-RW) I implement activities that require students to

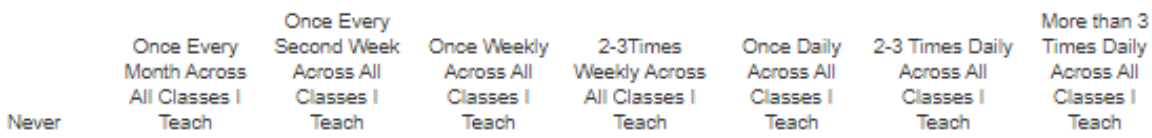

write routinely over

extended time frames,

reflection, and revision)

and shorter time frames

for a range of tasks,

purposes, and audiences.

10. (W-RL) I implement activities that require students to

develop personal, cultural,

and thematic connections

across genres.
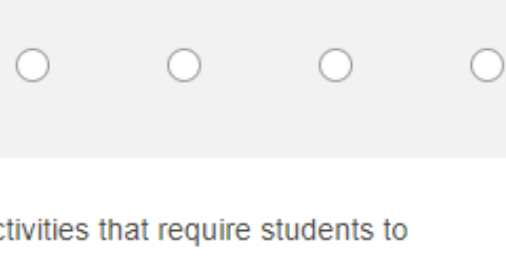

0
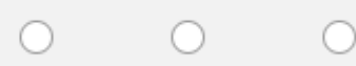
New York State Teachers' Stages of Concern and Extent of Implementation of English Language Arts Common Core State Standards in the Wake of Every Student Succeeds Act (ESSA)

7. COLLEGE AND CAREER READINESS STANDARDS FOR SPEAKING AND LISTENING

$7 / 19$ $37 \%$

\section{COMPREHENSION AND COLLABORATION (SL-CC)}

11. (SL-CC) I implement activities that require students to

$\begin{array}{ccccccc} & \text { Once Every } & & & & \text { More than } 3 \\ \text { Once Every } & \text { Second Week } & \text { Once Weekly } & \text { 2-3Times } & \text { Once Daily } & 2-3 \text { Times Daily } & \text { Times Daily } \\ \text { Month Across } & \text { Across All } & \text { Across All } & \text { Weekly Across } & \text { Across All } & \text { Across All } & \text { Across All } \\ \text { All Classes I } & \text { Classes I } & \text { Classes I } & \text { All Classes I } & \text { Classes I } & \text { Classes I } & \text { Classes I } \\ \text { Teach } & \text { Teach } & \text { Teach } & \text { Teach } & \text { Teach } & \text { Teach } & \text { Teach }\end{array}$

prepare for and participate

effectively in a range of

conversations and

collaborations with diverse

partners.

integrate and evaluate

information presented in

diverse media and

formats.

evaluate a speaker's point

of view, reasoning, and

use of evidence and

rhetoric.

Nerer

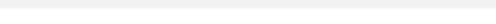

Prev

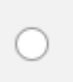

$\bigcirc$

$\bigcirc$

$\bigcirc$

$\bigcirc$

C

O

$\bigcirc$

$\bigcirc$

0

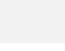

Powered by

Sh SurveyMonkey

See how easy it is to create a survey. 
New York State Teachers' Stages of Concern and Extent of Implementation of English Language Arts Common Core State Standards in the Wake of Every Student Succeeds Act (ESSA)

\section{COLLEGE AND CAREER READINESS STANDARDS FOR SPEAKING AND LISTENING}

$8 / 19$

$42 \%$

\section{PRESENTATION OF KNOWLEDGE AND IDEAS (SL-PKI)}

12. (PKI) I implement activities that require students to

$\begin{array}{ccccccc} & \text { Once Every } & & & & \text { More than } 3 \\ \text { Once Every } & \text { Second Week } & \text { Once Weekly } & \text { 2-3Times } & \text { Once Daily } & 2-3 \text { Times Daily } & \text { Times Daily } \\ \text { Month Across } & \text { Across All } & \text { Across All } & \text { Weekly Across } & \text { Across All } & \text { Across All } & \text { Across All } \\ \text { All Classes I } & \text { Classes I } & \text { Classes I } & \text { All Classes I } & \text { Classes I } & \text { Classes I } & \text { Classes I } \\ \text { Teach } & \text { Teach } & \text { Teach } & \text { Teach } & \text { Teach } & \text { Teach } & \text { Teach }\end{array}$

present information,

Never

Teach Teach

Teach

Teach

Teach

Teach

Teach

findings, and supporting

evidence such that

listeners can follow the

line of reasoning and the

organization,

development, and style.

make strategic use of

digital media and visual

displays of data to express

information and enhance

understanding of

presentations.

adapt speech to a variety

of contexts and

communicative tasks

demonstrating command

of formal English when

indicated or appropriate.

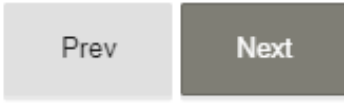

Powered by

SurveyMonkey

See how easy it is to create a survey. 
New York State Teachers' Stages of Concern and Extent of Implementation of English Language Arts Common Core State Standards in the Wake of Every Student Succeeds Act (ESSA)

\section{COLLEGE AND CAREER READINESS ANCHOR STANDARDS FOR LANGUAGE}

$\theta / 19$ $47 \%$

\section{CONVENTIONS OF STANDARD ENGLISH (CSE)}

13. (CSE) I implement activities that require students to

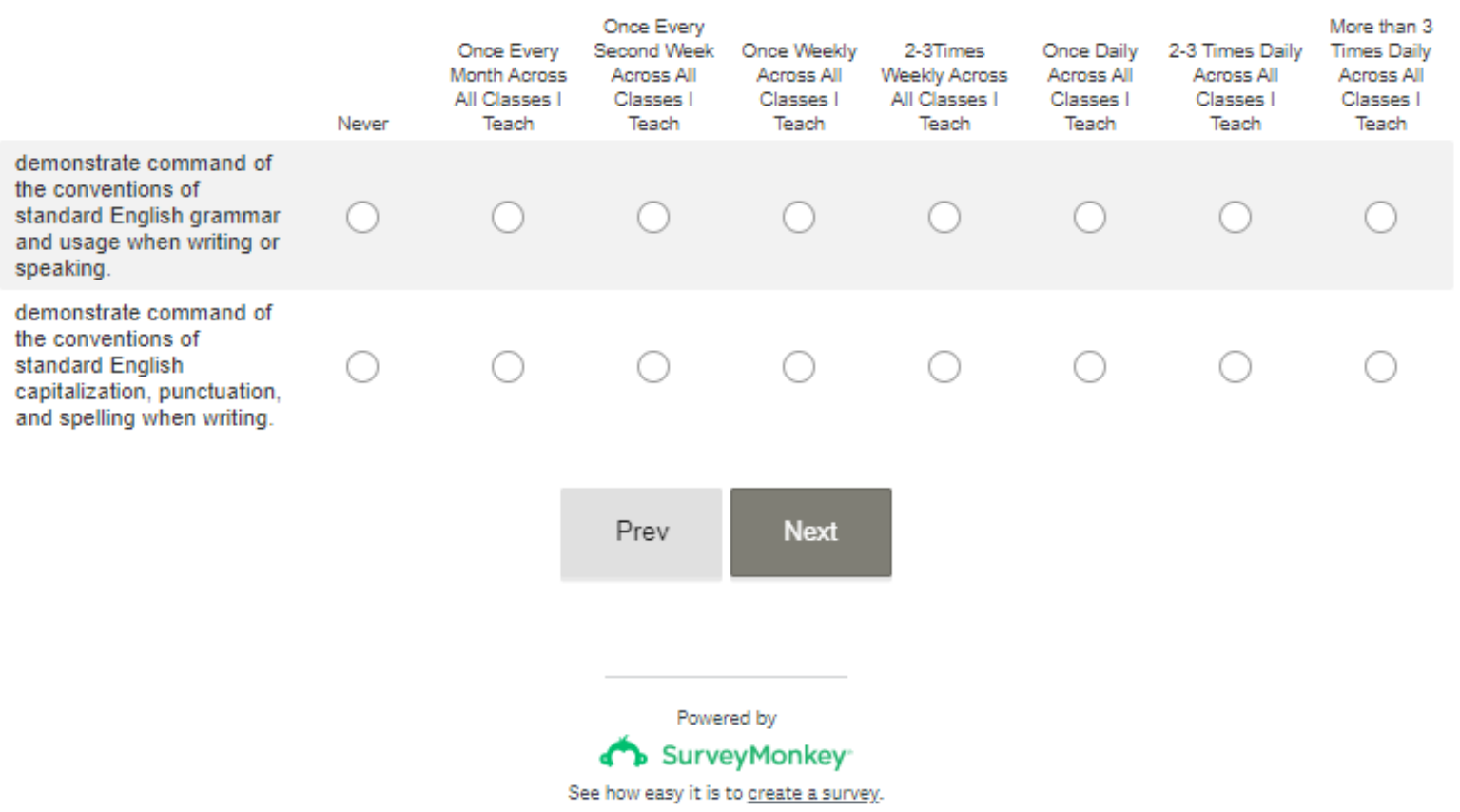


New York State Teachers' Stages of Concern and Extent of Implementation of English Language Arts Common Core State Standards in the Wake of Every Student Succeeds Act (ESSA)

\section{COLLEGE AND CAREER READINESS ANCHOR STANDARDS FOR LANGUAGE}

$10 / 18$

\section{KNOWLEDGE OF LANGUAGE (L-KL) \& VOCABULARY ACQUISITION AND USE (L-VAU)}

14. (L-KL) I implement activities that require students to

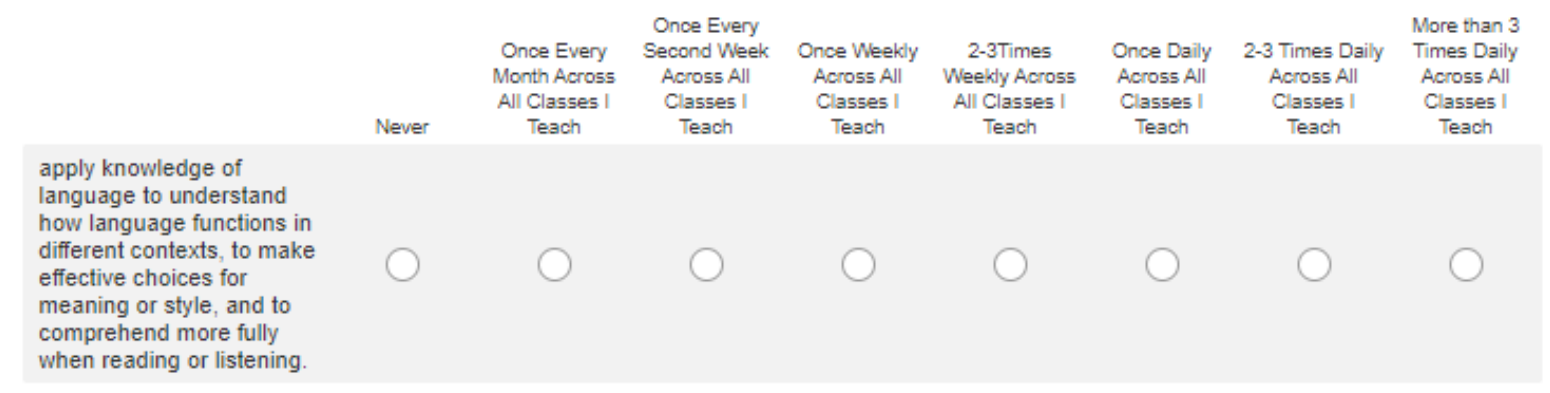

15. (L-VAU) I implement activities that require students to

\begin{tabular}{|c|c|c|c|c|c|c|c|c|}
\hline & Never & $\begin{array}{c}\text { Once Every } \\
\text { Month Across } \\
\text { All Classes I } \\
\text { Teach }\end{array}$ & $\begin{array}{c}\text { Once Every } \\
\text { Second Week } \\
\text { Across All } \\
\text { Classes I } \\
\text { Teach }\end{array}$ & $\begin{array}{c}\text { Once Weekly } \\
\text { Across All } \\
\text { Classes I } \\
\text { Teach }\end{array}$ & $\begin{array}{l}\text { 2-3 Times } \\
\text { Weekly Across } \\
\text { All Classes I } \\
\text { Teach }\end{array}$ & $\begin{array}{c}\text { Once Daily } \\
\text { Across All } \\
\text { Classes I } \\
\text { Teach }\end{array}$ & $\begin{array}{c}\text { 2-3 Times } \\
\text { Daily Across } \\
\text { All Classes I } \\
\text { Teach }\end{array}$ & $\begin{array}{c}\text { More Than } 3 \\
\text { Times Daily } \\
\text { Across All } \\
\text { Classes I } \\
\text { Teach }\end{array}$ \\
\hline \multicolumn{9}{|l|}{$\begin{array}{l}\text { determine or clarify the } \\
\text { meaning of unknown and } \\
\text { multiple-meaning words } \\
\text { and phrases. }\end{array}$} \\
\hline \multicolumn{9}{|l|}{$\begin{array}{l}\text { demonstrate } \\
\text { understanding of figurative } \\
\text { language, word } \\
\text { relationships, and nuances } \\
\text { in word meanings. }\end{array}$} \\
\hline $\begin{array}{l}\text { acquire and use } \\
\text { accurately a range of } \\
\text { general academic and } \\
\text { domain-specific words and } \\
\text { phrases. }\end{array}$ & & & & & & & & \\
\hline
\end{tabular}




\section{STAGES OF CONCERN QUESTIONNAIRE}

New York State Teachers' Stages of Concern and Extent of Implementation of English Language Arts Common Core State Standards in the Wake of Every Student Succeeds Act (ESSA)

\section{Stages of Concern Questionnaire:1-5}

$11 / 18$ $58 \%$

Use this response scale to guide your answers: 12 $3 \quad 4 \quad 5$ 67

Irrelevant Not true of me now Somewhat true of me now Very true of me know

16. In terms of the Common Core State Standards as an innovation

I am concerned about
students' attitude toward
the innovation.
I now know of some other
approaches that might
work better.
I am more concerned
about another innovation
I am concerned about not
having enough time to
organize myself each day.
I would like to help other
faculty in their use of the
innovation

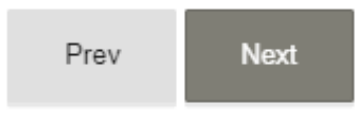

Powered by

SurveyMonkey

See how easy it is to create a survey. 
New York State Teachers' Stages of Concern and Extent of Implementation of English Language Arts Common Core State Standards in the Wake of Every Student Succeeds Act (ESSA)

12. Stages of Concern Questionnaire: 6-10

$12 / 19$ $63 \%$

Use this response scale to guide your answers:
0
12
$\begin{array}{lll}3 & 4 & 5\end{array}$
67

Irrelevant Not true of me now Somewhat true of me now Very true of me know

17. In terms of the Common Core State Standards as an innovation

I have a very limited
knowledge of the
innovation.
I would like to know the
effect of reorganization on
my professional status.
I am concerned about
conflict between my
interests and my
responsibilities.
I am concerned about
revising my use of the
innovation.
I would like to develop
working relationships with
both our faculty and
outside faculty using this
innovation.

\section{Prev Next}

Powered by

ho SurveyMonkey

See how easy it is to create a survey. 
New York State Teachers' Stages of Concern and Extent of Implementation of English Language Arts Common Core State Standards in the Wake of Every Student Succeeds Act (ESSA)

13. Stages of Concern Questionnaire: 11-15

$13 / 19$

$68 \%$

Use this response scale to guide your answers:

$\begin{array}{lllllllll}0 & 1 & 2 & 3 & 4 & 5 & 6 & 7\end{array}$

Irrelevant Not true of me now Somewhat true of me now Very true of me know

18. In terms of the Common Core State Standards as an innovation

I am concerned about how
the innovation affects
students.
I am not concerned about
the innovation at this time.
I would like to know who
will make decisions in the
new system.
I would like to discuss the
possibility of using the
innovation.
I would like to know what
resources are available if
we decide to adopt the
innovation.

Prev Next

Powered by

ho SurveyMonkey

See how easy it is to create a survey. 
New York State Teachers' Stages of Concern and Extent of Implementation of English Language Arts Common Core State Standards in the Wake of Every Student Succeeds Act (ESSA)

14. Stages of Concern Questionnaire: $16-20$

$14 / 18$ $74 \%$

Use this response scale to guide your answers:

$\begin{array}{cccccccc}0 & 1 & 2 & 3 & 4 & 5 & 6 & 7 \\ \text { Irelevant } & \text { Not true of me now } & & \text { Somewhat true of me now } & \text { Very true of me know }\end{array}$

19. In terms of the Common Core State Standards as an innovation

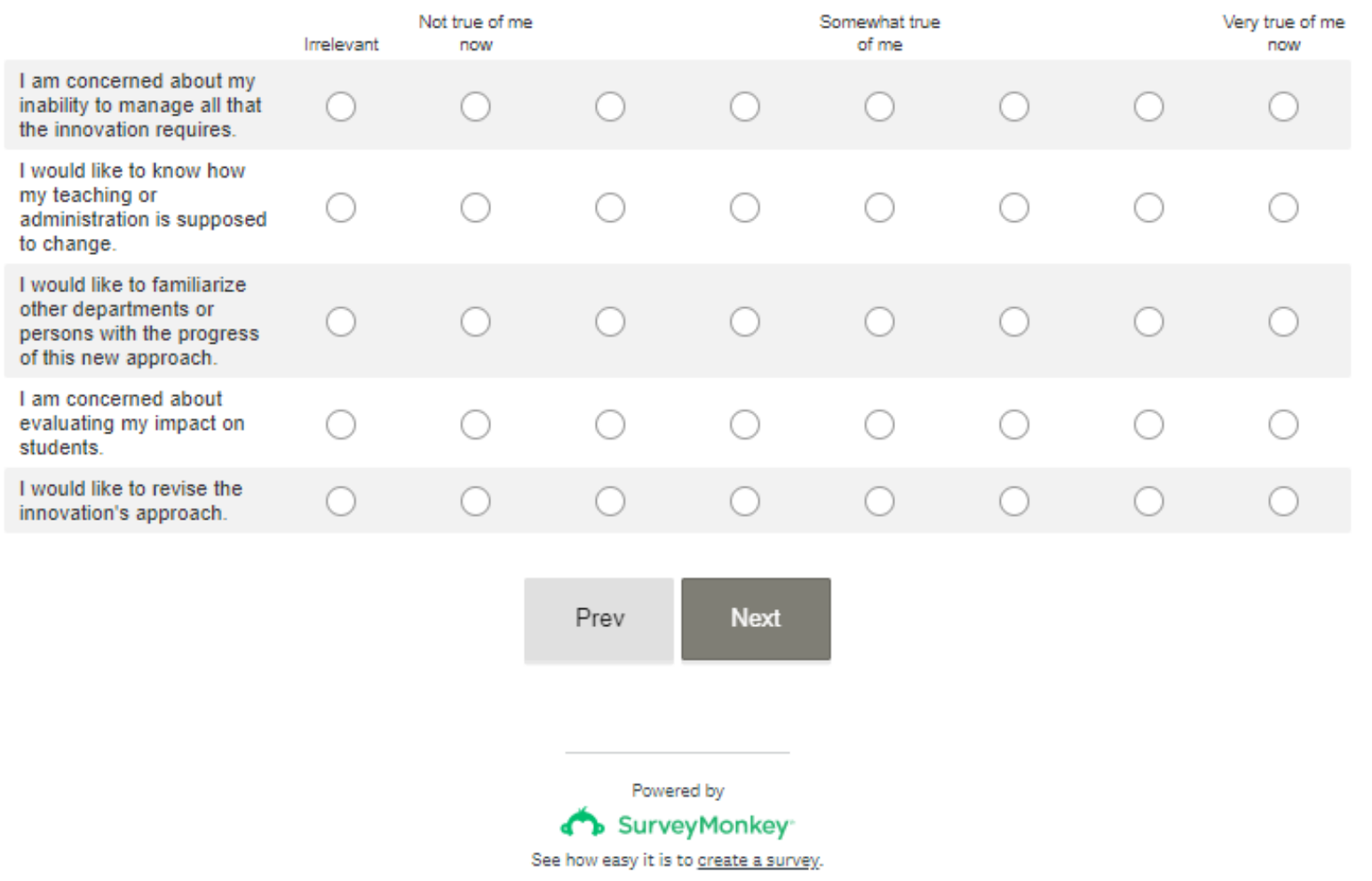


New York State Teachers' Stages of Concern and Extent of Implementation of English Language Arts Common Core State Standards in the Wake of Every Student Succeeds Act (ESSA)

15. Stages of Concern Questionnaire: 21-25

$15 / 19$ $79 \%$

Use this response scale to guide your answers:

$\begin{array}{cccccccc}0 & 1 & 2 & 3 & 4 & 5 & 6 & 7 \\ \text { Irelevant } & \text { Not true of me now } & \text { Somewhat true of me now } & \text { Very true of me know }\end{array}$

20. In terms of the Common Core State Standards as an innovation

I am preoccupied with
things other than the
innovation.
I would like to modify our
use of the innovation
based on the experiences
of our students.
I spend little time thinking
about the innovation.
I would like to excite my
students about their part in
this approach.
I am concerned about time
spent working with
nonacademic problems
related to the innovation.


New York State Teachers' Stages of Concern and Extent of Implementation of English Language Arts Common Core State Standards in the Wake of Every Student Succeeds Act (ESSA)

\section{Stages of Concern Questionnaire: $26-30$}

$16 / 19$ $84 \%$

Use this response scale to guide your answers:

$\begin{array}{cccccccc}0 & 1 & 2 & 3 & 4 & 5 & 6 & 7 \\ \text { Intevant } & \text { Not true of me now } & \text { Somewhat true of me now } & \text { Very true of me know }\end{array}$

21. In terms of the Common Core State Standards as an innovation

I would like to know what
the use of the innovation
will require in the
immediate future.
I would like to coordinate
my efforts with others to
maximize the innovation's
effects.
I would like to have more
information on time and
energy commitments
required by the innovation.
I would like to know what
other faculty are doing in
this area.
Currently, other priorities
prevent me from focusing
my attention on the
innovation.

\section{Prev Next}

Powered by

SurveyMonkey

See how easy it is to create a survey. 
New York State Teachers' Stages of Concern and Extent of Implementation of English Language Arts Common Core State Standards in the Wake of Every Student Succeeds Act (ESSA)

17. Stages of Concern Questionnaire: 31-35

$17 / 19$ $89 \%$

Use this response scale to guide your answers:

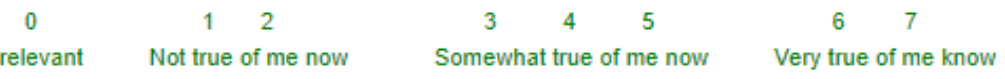

22. In terms of the Common Core State Standards as an innovation

I would like to determine
how to supplement,
enhance, or replace the
innovation.
I would like to use
feedback from students to
change the program.
I would like to know how
my role will change when I
am using the innovation.
Coordination of tasks and
people is taking too much
of my time.
I would like know how the
innovation is better than
what we have now/used to
have.

Powered by

the SurveyMonkey

See how easy it is to create a survey- 


\section{Demographic and Clarifying Questions}

New York State Teachers' Stages of Concern and Extent of Implementation of English Language Arts Common Core State Standards in the Wake of Every Student Succeeds Act (ESSA)

\section{Open-Ended Questions}

$18 / 19$ $95 \%$

23. How long have you been involved with Common Core State Standards, not counting this year?

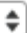

24. In your implementation of the Common Core State Standards, do you consider yourself to be a:

25. Have you received adequate formal training regarding the implementation of the Common Core State Standards?

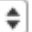

26. What do you consider your biggest concem overall?

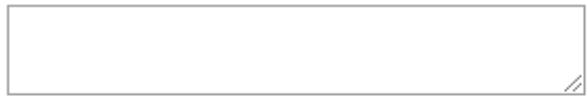

27. Overall, what are the major concerns you have with Common Core State Standards? If possible, list them in order of importance beginning with the most important concern.

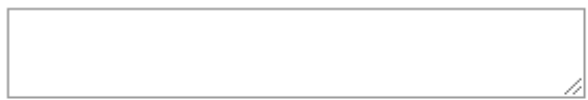

28. How would you describe your professional development needs?

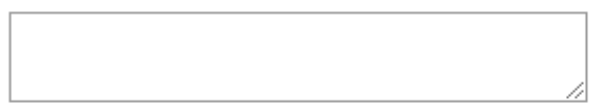

29. What are your professional development needs?

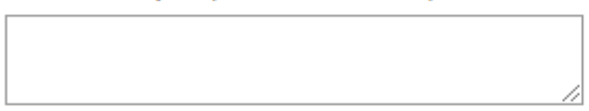

30. How would you describe the professional development you are currently getting?

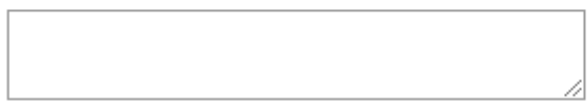

31. How would you describe your professional development needs?

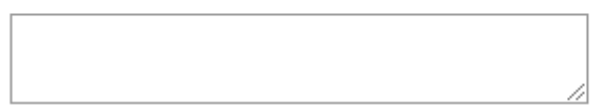


New York State Teachers' Stages of Concern and Extent of Implementation of English Language Arts

Common Core State Standards in the Wake of Every Student Succeeds Act (ESSA)

\section{DEMOGRAPHIC DATA}

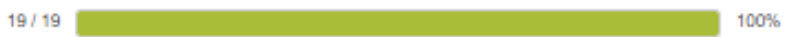

Please give me a little information about yourself to help me understand other factors that will contribute to the usefulness of this study when it is completed. All the information you give are confidential and would not personally identify you. There are no hidden codes to track you personally. All Andrews University IRB privacy protocols are observed in this study.

32. Wat is your public school type?

$\rightarrow$

33. What is your tenure status?

$\rightarrow$

34. How many years have you implemented the Common Core State Standards?

$\rightarrow$

35. What category of students do you mostly teach?

\section{$\rightarrow$}

36. How many years have you been teaching ELA?

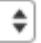

37. What is your highest level of education?

\section{$\rightarrow$}

38. Are you certified to teach English Language Arts and/or ENL, LEP students?

\section{$\rightarrow$}

39. What grade levels do you teach?

$\rightarrow$

40. What is your gender?

\section{$\rightarrow$}

41. Which of these groups describe you?

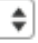

42. What is your age range? Drag the slider from left to right until it reaches your age. 


\section{CHARLOTTE DANIELSON'S FRAMEWORK FOR TEACHING}

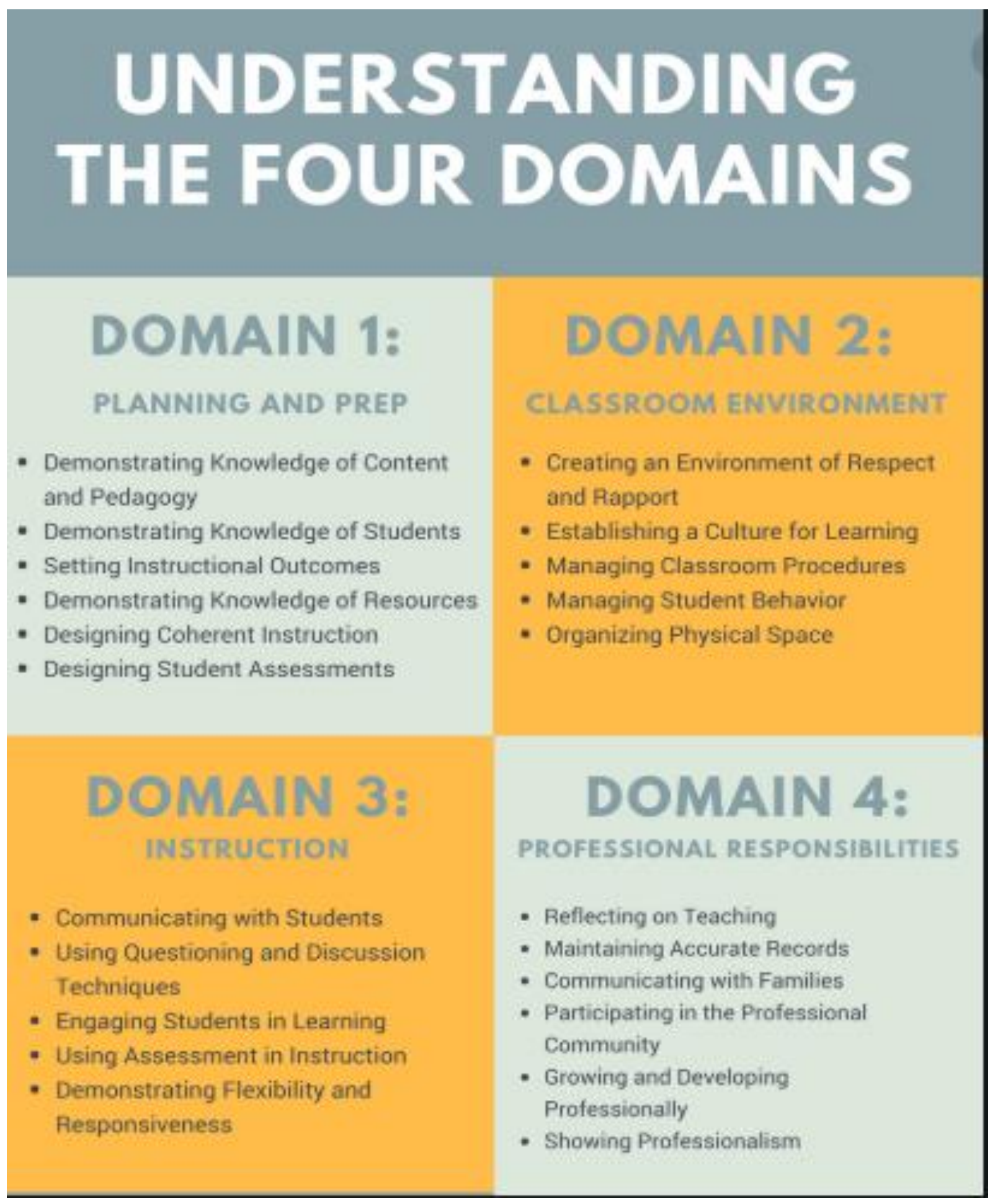




\section{CHARLOTTE DANIELSON'S FRAMEWORK FOR TEACHING (Continued)}

\section{Domain 4: Professional Responsibilities}

\begin{tabular}{|c|c|c|c|c|c|}
\hline & Component & Unsatisfactory & Basic & Proficient & Distinguished \\
\hline & $\begin{array}{l}\text { Reflecting on } \\
\text { Teaching }\end{array}$ & $\begin{array}{l}\text { The teacher does not know whether a lesson was } \\
\text { effective or achieved its instructional outcomes, or the } \\
\text { teacher profoundly misjudges the success of a lesson. } \\
\text { The teacher has no suggestions for how a lesson could } \\
\text { be improved. }\end{array}$ & $\begin{array}{l}\text { The teacher has a generally accurate impression } \\
\text { of a lesson's effectiveness and the extent to which } \\
\text { instructional outcomes were met. The teacher makes } \\
\text { general suggestions about how a lesson could be } \\
\text { improved. }\end{array}$ & $\begin{array}{l}\text { The teacher makes an accurate assessment of a lesson's } \\
\text { effectiveness and the extent to which it achieved its } \\
\text { instructional outcomes and can cite general references } \\
\text { to support the judgment. The teacher makes a few } \\
\text { specific suggestions of what could be tried another time } \\
\text { the lesson is taught. }\end{array}$ & $\begin{array}{l}\text { The teacher makes a thoughtful and accurate assessment of } \\
\text { a lesson's effectiveness and the extent to which it achieved its } \\
\text { instructional outcomes, citing many specific examples from } \\
\text { the lesson and weighing the relative strengths of each. Drawing } \\
\text { on an extensive repertoire of skills, the teacher offers specific } \\
\text { alternative actions, complete with the probable success of } \\
\text { different courses of action. }\end{array}$ \\
\hline & $\begin{array}{l}\text { Maintaining Accurate } \\
\text { Records }\end{array}$ & \begin{tabular}{|l|} 
The teacher's system for maintaining information on \\
student completion of assignments and student progress \\
in learning is nonexistent or in disarray. The teacher's \\
records for noninstructional activities are in disarray, \\
the result being errors and confusion.
\end{tabular} & $\begin{array}{l}\text { The teacher's system for maintaining information on } \\
\text { student completion of assignments and student progress } \\
\text { in learning is rudimentary and only partially effective. } \\
\text { The teacher's records for noninstructional activities } \\
\text { are adequate but inefficient and, unless given frequent } \\
\text { oversight by the teacher, prone to errors. }\end{array}$ & \begin{tabular}{|l|} 
The teacher's system for maintaining information on \\
student completion of assignments, student progress in \\
learning, and noninstructional records is fully effective.
\end{tabular} & $\begin{array}{l}\text { The teacher's system for maintaining information on student } \\
\text { completion of assignments, student progress in learning, and } \\
\text { noninstructional records is fully feffective. Students contribute } \\
\text { information and participate in maintaining the records. }\end{array}$ \\
\hline $4 \mathrm{c}:$ & $\begin{array}{l}\text { Communicating with } \\
\text { Families }\end{array}$ & \begin{tabular}{|l|} 
The teacher provides little information about the \\
instructional program to families; the teacher's \\
communication about students' progress is minimal. \\
The teacher does not respond, or responds insensitively, \\
to parental concerns.
\end{tabular} & \begin{tabular}{|l|} 
The teacher makes sporadic attempts to communicate \\
with families about the instructional program and \\
about the progress of individual students but does not \\
attempt to engage families in the instructional program. \\
Moreover, the communication that does take place may \\
not be culturally sensitive to those families.
\end{tabular} & $\begin{array}{l}\text { The teacher provides frequent and appropriate } \\
\text { information to families about the instructional } \\
\text { program and conveys information about individual } \\
\text { student progress in a culturally sensitive manner. The } \\
\text { teacher makes some attempts to engage families in the } \\
\text { instructional program. }\end{array}$ & $\begin{array}{l}\text { The teacher communicates frequently with families in a } \\
\text { culturally sensitive manner, with students contributing to the } \\
\text { communication. The teacher responds to family concerns with } \\
\text { professional and cultural sensitivity. The teacher's efforts to } \\
\text { engage families in the instructional program are frequent and } \\
\text { successful. }\end{array}$ \\
\hline 4d: & $\begin{array}{l}\text { Participating in } \\
\text { the Professional } \\
\text { Community }\end{array}$ & $\begin{array}{l}\text { The teacher's relationships with colleagues are negative } \\
\text { or self-serving. The teacher avoids participation in a } \\
\text { professional culture of inquiry, resisting opportunities to } \\
\text { become involved. The teacher avoids becoming involved } \\
\text { in school events or school and district projects. }\end{array}$ & $\begin{array}{l}\text { The teacher maintains cordial relationships with } \\
\text { colleagues to fulfill duties that the school or district } \\
\text { requires. The teacher participates in the school's culture } \\
\text { of professional inquiry when invited to do so. The } \\
\text { teacher participates in school events and school and } \\
\text { district projects when specifically asked. }\end{array}$ & $\begin{array}{l}\text { The teacher's relationships with colleagues are } \\
\text { characterized by mutual support and cooperation; the } \\
\text { teacher actively participates in a culture of professional } \\
\text { inquiry. The teacher volunteers to participate in school } \\
\text { events and in school and district projects, making a } \\
\text { substantial contribution. }\end{array}$ & $\begin{array}{l}\text { The teacher's relationships with colleagues are characterized } \\
\text { by mutual support and cooperation, with the teacher taking } \\
\text { initiative in assuming leadership among the faculty. The teacher } \\
\text { takes a leadership role in promoting a culture of professional } \\
\text { inquiry. The teacher volunteers to participate in school events } \\
\text { and district projects, making a substantial contribution and } \\
\text { asssuming a leadership role in at least one aspect of school or } \\
\text { district life. }\end{array}$ \\
\hline 4e: & $\begin{array}{l}\text { Growing and } \\
\text { Developing } \\
\text { Professionally }\end{array}$ & \begin{tabular}{|l|} 
The teacher engages in no professional development \\
activities to enhance knowledge or skill. The teacher \\
resists feedback on teaching performance from either \\
supervisors or more experienced colleagues. The teacher \\
makes no effort to share knowledge with others or to \\
assume professional responsibilities.
\end{tabular} & $\begin{array}{l}\text { The teacher participates to a limited extent in } \\
\text { professional activities when they are convenient. The } \\
\text { teacher engages in a limited way with colleagues and } \\
\text { supervisors in professional conversation about practice, } \\
\text { including some feedback on teaching performance. The } \\
\text { teacher finds limited ways to assist other teachers and } \\
\text { contribute to the profession. }\end{array}$ & \begin{tabular}{|l|} 
The teacher seeks out opportunities for professional \\
development to enhance content knowledge and \\
pedagogical skill. The teacher actively engages with \\
colleagues and supervisors in professional conversation \\
about practice, including feedback about practice. The \\
teacher participates actively in assisting other educators \\
and looks for ways to contribute to the profession.
\end{tabular} & $\begin{array}{l}\text { The teacher seeks out opportunities for professional } \\
\text { development and makes a systematic effort to conduct action } \\
\text { research. The teacher solicits feedback on practice from both } \\
\text { supervisors and colleagues. The teacher initiates important } \\
\text { activities to contribute to the profession. }\end{array}$ \\
\hline $4 \mathrm{f}$ & $\begin{array}{l}\text { Showing } \\
\text { Professionalism }\end{array}$ & $\begin{array}{l}\text { The teacher displays dishonesty in interactions with } \\
\text { colleagues, students, and the public. The teacher } \\
\text { is not alert to students' needs and contributes to } \\
\text { school practices that result in some students' being } \\
\text { ill served by the school. The teacher makes decisions } \\
\text { and recommendations that are based on self-serving } \\
\text { interests. The teacher does not comply with school and } \\
\text { district regulations. }\end{array}$ & $\begin{array}{l}\text { The teacher is honest in interactions with colleagues, } \\
\text { students, and the public. The teacher's attempts to serve } \\
\text { students are inconsistent, and unknowingly contributes } \\
\text { to some students being ill served by the school. The } \\
\text { teacher's decisions and recommendations are based on } \\
\text { limited though genuinely professional considerations. } \\
\text { The teacher must be reminded by supervisors about } \\
\text { complying with school and district regulations. }\end{array}$ & $\begin{array}{l}\text { The teacher displays high standards of honesty, integrity, } \\
\text { and confidentiality in interactions with colleagues, } \\
\text { students, and the public. The teacher is active in serving } \\
\text { students, working to ensure that all students receive a } \\
\text { fair opportunity to succeed. The teacher maintains an } \\
\text { open mind in team or departmental decision making. } \\
\text { The teacher complies fully with school and district } \\
\text { regulations. }\end{array}$ & $\begin{array}{l}\text { The teacher can be counted on to hold the highest standards } \\
\text { of honesty, integrity, and confidentiality and takes a leadership } \\
\text { role with colleagues. The teacher is highly proactive in serving } \\
\text { students, seeking out resources when needed. The teacher } \\
\text { makes a concerted effort to challenge negative attitudes } \\
\text { or practices to ensure that all students, particularly those } \\
\text { traditionally underserved, are honored in the school. The } \\
\text { teacher takes a leadership role in team or departmental decision } \\
\text { making and helps ensure that such decisions are based on the } \\
\text { highest professional standards. The teacher complies fully with } \\
\text { school and district regulations, taking a leadership role with } \\
\text { colleagues. }\end{array}$ \\
\hline
\end{tabular}

Excerpt from The Framework for Teaching Evaluation Instrument, 2013 Edition. Copyright $\otimes 2013$ The Danielson Group. All rights reserved. 


\title{
APPENDIX D
}

\section{ANDREWS UNIVERSITY IRB APPROVAL}

\section{RE: IRB 17-018 MODIFICATION EXEMPT DETERMINATION}

2 messages

IRB <irb@andrews.edu>

Mon, Apr 17, 2017 at 5:41 PM

To: Alozie Ogbonna <alozie247@gmail.com>, Larry Burton <burton@andrews.edu>

Dear Alozie,

Your IRB modification application for approval of research involving human subjects entitled: 'New York State teachers' stages of concern and extent of implementation of English Language Arts common state standards in the wake of Every Student Succeeds Act (ESSA)" IRB protocol \# 17-018 has been evaluated and determined Exempt from IRB review under regulation 46.101 (b) (2). Please find attached your letter of determination.

Thank you.

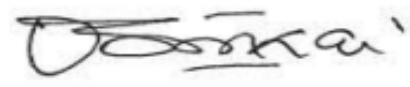

\section{Mordekai Ongo}

\author{
Research Integrity \& Compliance Officer \\ Andrews University \\ 4150 Administration Dr \\ Berrien Springs, MI 49104-4910 \\ Tel. Office: 269-471-6361 \\ Email: irb@andrews.edu
}




\title{
Andrews $\mathbf{Q}$ University
}

April 17, 2017

Alozie Ogbonna

Tel. (917) 515-7889

Email: ogbanna@andrews.edu

\begin{abstract}
RE: APPLICATION FOR APPROVAL OF RESEARCH INVOLVING HUMAN SUBJECTS
IRB Protocol \# :17-018 Application Type: Original Dept.: Curriculum \& Instruction Review Category: Exempt Action Taken: Approved Advisor: Larry Burton

Title: New York State teachers' stages of concern and extent of implementation of English Language Arts common state standards in the wake of Every Student Succeeds Act (ESSA).
\end{abstract}

Your IRB modification application for approval of research involving human subjects entitled: 'New York State teachers' stages of concern and extent of implementation of English Language Arts common state standards in the wake of Every Student Succeeds Act (ESSA)" IRB protocol \# 17-018 has been evaluated and determined Exempt from IRB review under regulation 46.101 (b) (2). You may now proceed with your research.

Please note that any future changes (see IRB Handbook pages 11-12) made to the study design and/or informed consent form require prior approval from the IRB before such changes can be implemented. Incase you need to make changes please use the attached report form.

While there appears to be no more than minimum risks with your study, should an incidence occur that results in a research-related adverse reaction and/or physical injury, (see IRB Handbook pages 12) this must be reported immediately in writing to the IRB. Any research-related physical injury must also be reported immediately to the University Physician, Dr. Katherine, by calling (269) 473-2222.

We ask that you reference the protocol number in any future correspondence regarding this study for easy retrieval of information.

Best wishes in your research.

Sincerely,

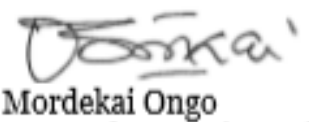

Research Integrity and Complaince Officer

Institutional Review Board - 4150 Administration Dr Room 322 - Berrien Springs, MI 49104-0355 Tel: (269) 471-6361 Fax: (269) 471-6543 E-mail: irb@andrews.edu 


\section{APPENDIX E}

\section{NEW YORK CITY DEPARTMENT OF EDUCATION IRB APPROVAL}

\section{NYC Department of Education (NYCDOE) Service Provider Information (Please open - Action required)}

1 message

PETSAdminSupport@schools.nyc.gov <PETSAdminSupport@schools.nyc.gov>

To: alozie247@gmail.com

Dear Alozie Ogbonna ,

Congratulations!

This email confirms that an organization or agency providing services to the NYC Department of Education (NYCDOE) has nominated you for a position. This email covers paid positions and unpaid roles such as student teachers and volunteers. In order for you to begin working or providing services, your prompt action is required. This nomination is contingent upon a satisfactory outcome of several pre-employment screening activities including: fingerprinting, the completion of a questionnaire and a security clearance review. Please be advised that if the DOE does not grant you security. clearance, your nomination is rescinded effective immediately and you may not work for or provide services to the DOE.

Security Clearance Required:

Any person working in the New York City DOE buildings, working with NYC DOE students or who has access to NYCDOE confidential information is required by New York State law to undergo a fingerprint-supported security review prior to commencing services. All prospective employees (either working for theNYCDOE, a Vendor or in an unpaid role) must have a security clearance before starting work. No one can be fingerprinted by the NYCDOE or undergo the security clearance unless they have been added to the organization or agency's PETS (Personnel Eligibility Tracking System) roster.

\section{Applicant Gateway:}

Your next step is to log into the DOE's Applicant Gateway!ıMPORTANT NOTE: To ensure that you correctly activate your account, you must use the same email address this nomination was sent to. If for any reason you must use a different email address than the one you originally provided, you must notify your hiring manager as soon as possible. Once in the Gateway, follow the specific steps required and fill out any required forms. Please visit the NYCDOE Applicant Gateway athttps://www.nycenet.edu/Offices/DHR/agway/ and see the 'Forms Requiring Action' column for information. 
Valid Social Security_Number

Any person being fingerprinted to work in a NYCDOE school or for a NYCOE program must have a VALID Social Security Number (SSN) issued by the Social Security Administration (SSA) and assigned to the person undergoing the security clearance review. Using a number other than your own VALID SSN is exposing yourself to possible persecution for identity fraud.

If you login into Applicant Gateway and your Social Security number listed is incorrect, immediately contact the employer/office that added you to PETS. Failure to address this issue prior to being fingerprinted may result in new fingerprints needing to betaken at anadditional cost to you.

\section{Fingerprinting}

If the Applicant Gateway indicates you need to be fingerprinted, please print the Fingerprint Referral Form (in the Applicant Gateway). This form can be printed only after you have completed all other required forms. Bring the Fingerprint Referral Form and a valid government-issued photo ID (US Passport, State driver's license, etc.) to:

\section{HR Connect Walk-In Center Division of Human Resources 65 Court Street, Room 102 (between Livingston \& Joralemon Streets) Brooklyn, N.Y. 11201}

Bus Attendants Only: Please note that Bus Attendants should not report to the HR Connect Walk-In Center for fingerprinting. Instead, Bus Attendants should report to the following:

\section{Office of Pupil Transportation \\ 44-36 Vernon Boulevard \\ Long Island City, NY 11101}

The HR Connect Walk-In Center is open every business day from 8:30 AM to 5:00 PM. The telephone number is 718-935-4000. The cost of fingerprinting effective July 1st, 2016 is $\$ 135$; you may pay by check, money order, or credit card (Note: cash is NOT accepted). Please come in to be fingerprinted as soon as possible, but no later than 10 days after you receive this letter. Please note that this process is required in order for your security clearance to proceed.

\footnotetext{
**Please remember that you may not work or provide services until your employer, agency or organization confirms in PETS your eligibility to start work. Your employer will then determine your actual first day of employment and work schedule. Please be advised that you will not get paid for any work completed prior to obtaining security clearance.
} 
Please be advised that all vendor applicants who complete the security clearance process are subject to Chancellor's Regulation C-105, here: http://docs.nycenet.edu/ docushare/dsweb/Get/Document-55/C-105.pdf

If you have any questions, please email oPIINFO@schools.nyc.gorwith your inquiry. You will receive a response within one (1) business day.

\section{Sincerely,}

New York City Department of Education

Ref Number : GX3350961 N332 PETS Nomination 
NIH CERTIFICATE OF COMPLETION OF TRAINING ON "PROTECTION O FHUMAN RESEARCH PARTICIPANTS"

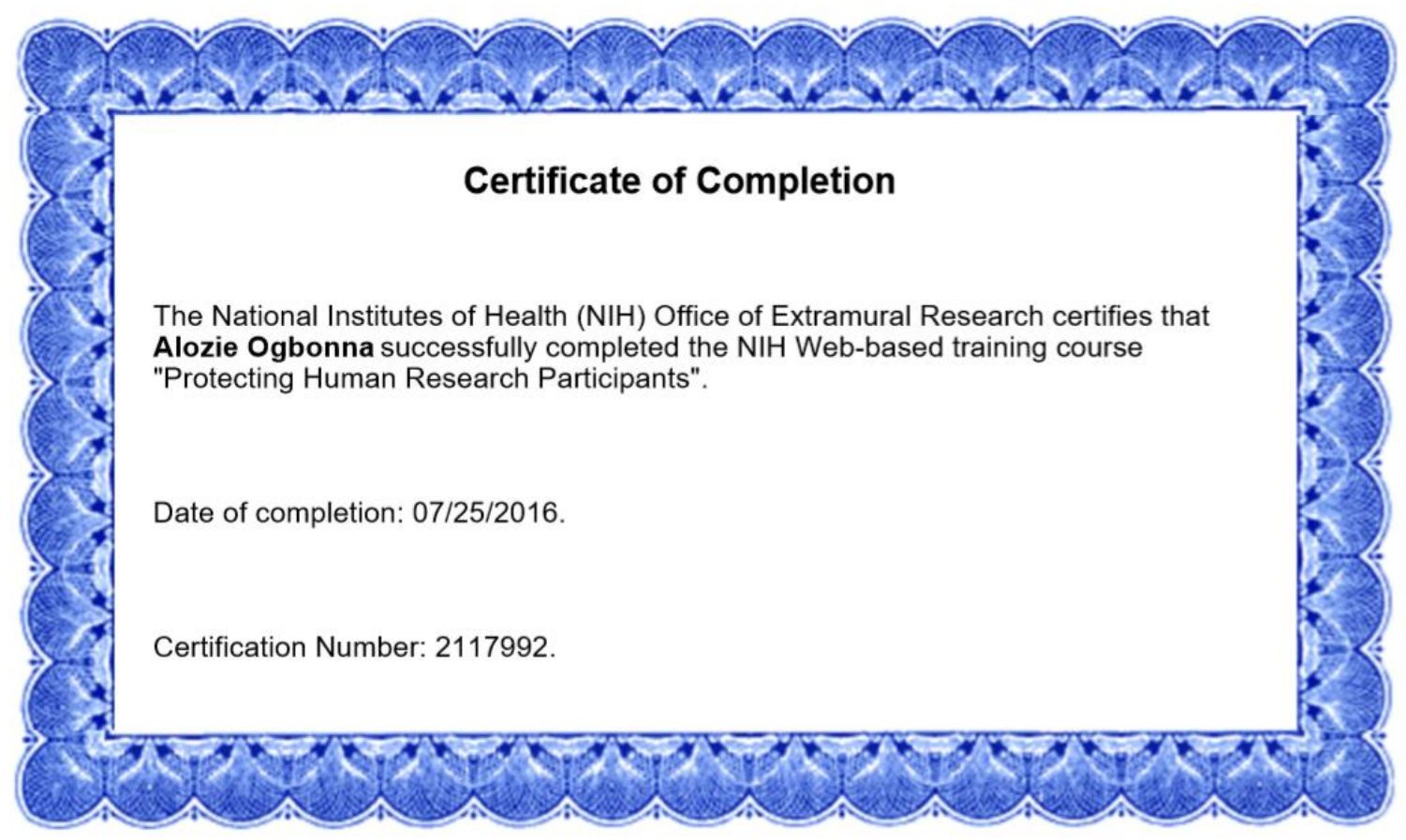




\section{APPENDIX G}

\section{SOLICITATION FOR PARTICIPATION CARD}

Dear English Teacher,

CALL FOR PARTICIPATION: ELA COMMON CORE STUDY

ELA TEACHERS GRADES 6-12 - fellow ELA teacher seeking participants to complete a short ANONYMOUS survey for doctoral dissertation: New York State Teachers' Stages of Concern and Extent of Implementation of ELA Common Core State Standards in the Wake of Every Student Succeeds Act (ESSA). The survey can be found through any of the two links below:

\section{www.commoncorestudy.weebly.com}

\section{or https://surveymonkey.com/r/NYS_ELA}

Your involvement in this study is voluntary and anonymous. The only expectation for participants is to complete an electronic survey. The survey should take no longer than 10 minutes to complete. INCLUSION: Grades 6-12 ELAVENLESLTESOL teachers who have implemented, or are currently implementing ELA Common Core State Standards. Participants will not be contacted after the completion of the survey. Please participate. Thank you for your anticipated participation.

APPROVED BY THE NEW YORK CITY DEPT. OF EDUCATION IRB: FILE \# 1980 


\section{APPENDIX H}

\section{SOLICITATION FOR PARTICIPATION IN THE NYSUT NEWSPAPER}

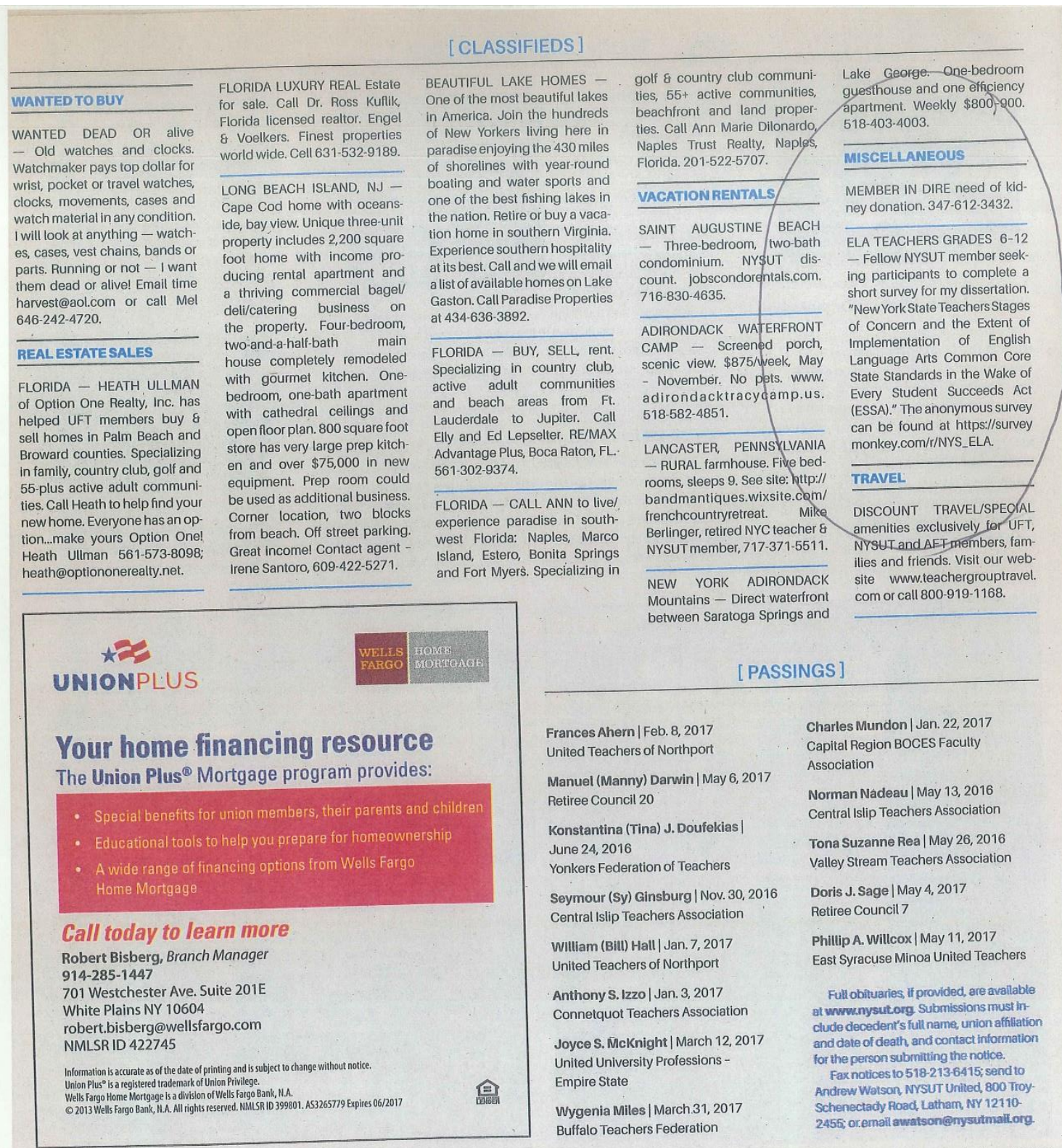

Page 20 | June 2017

Official Publication of NYSUT 


\section{APPENDIX I}

\section{SOLICITATION FOR PARTICIPATION IN THE NEW YORK DAILY NEWS}

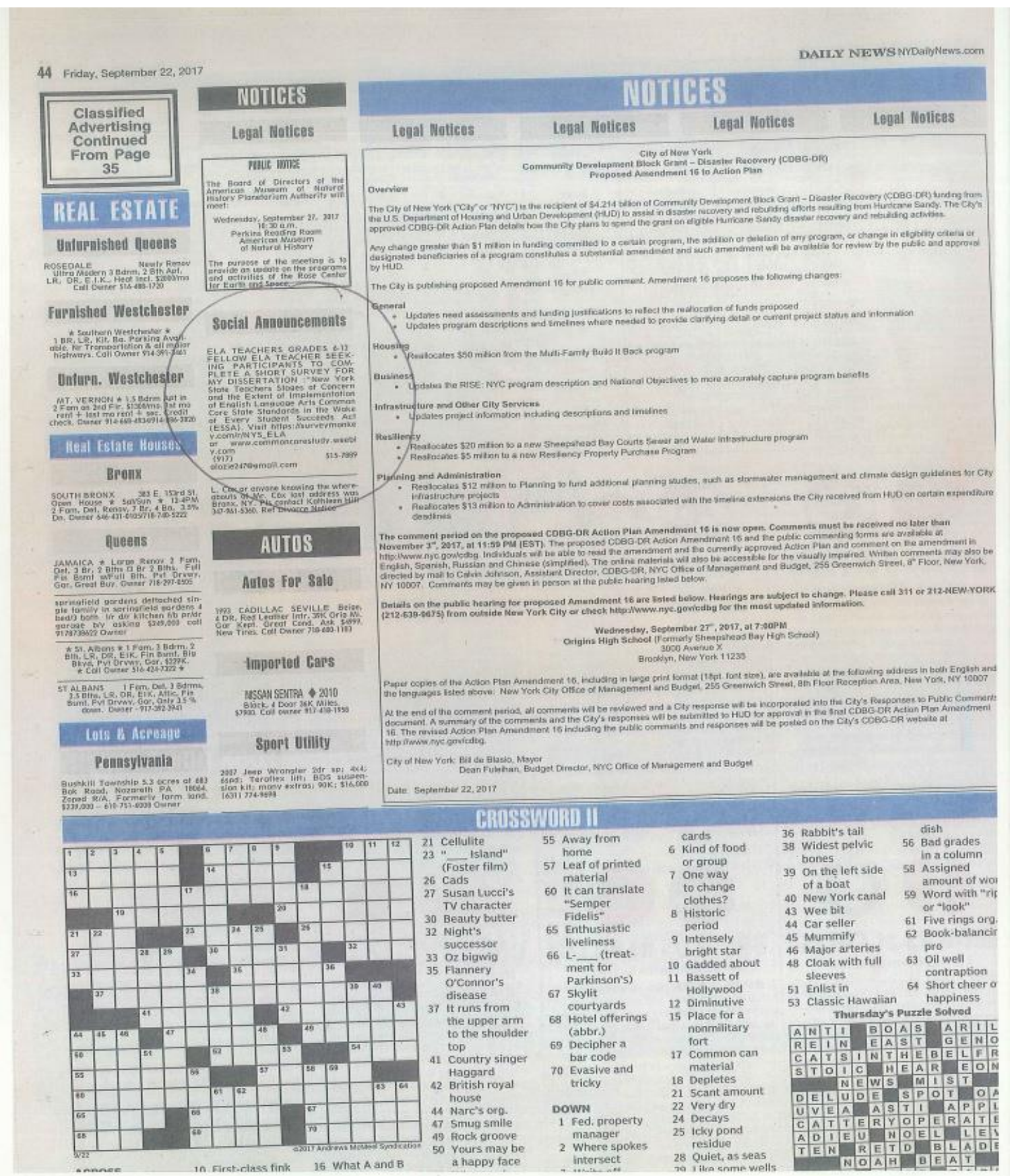




\section{APPENDIX J}

\section{EMAIL SOLICITATION FOR PARTICIPATION}

Dear fellow English teacher,

Please kindly complete my doctoral dissertation survey briefly described below. Click on any of the two links below for a full introduction to the study and to take the survey.

Thanks

Alozie Ogbonna, SVHS

ELA/ENL/ESL/TESOL TEACHERS GRADES 6-12 - fellow teacher seeking participants to complete a short survey for dissertation: "New York State Teachers' Stages of Concern and the Extent of Implementation of English Language Arts Common Core State Standards in the Wake of Every Student Succeeds Act (ESSA)."

Approved by Andrews University IRB and New York City Dept. of Education IRB (Approval \# 1980).

The anonymous survey can be found at https://surveymonkey.com/r/NYS_ELA

or

www.commoncorestudy.weebly.com 


\section{REFERENCE LIST}

Anderson, L. W., \& Krathwohl, D. R. (2001). A taxonomy for learning, teaching, and assessing: a revision of Bloom's taxonomy of educational objectives (Complete ed.). New York: Longman.

Amore, A., Hoeflich, N. M., \& Pennington, K. (2015). Teacher leadership:

The pathway to Common Core success. Retrieved on June 4, 2020, from https://cdn.americanprogress.org/wpcontent/uploads/2015/04/CCTeacherVoiceFinal.pdf

Ballard, K., \& Bates, A. (2008). Making a connection between student achievement, teacher accountability, and quality classroom instruction, The Qualitative Report, 13(4), 560-580. Available at: http://www.nova.edu/ssss/QR/QR13-4/ballard.pdf/.

Barlowe, A. \& Cook, A (2016). Putting the focus on student engagement: Benefits of performance-based assessment. American Educator. Spring, 2016

Barshay, J. (2019) Five years after Common Core, a mysterious spike in failure rate among NY high school students: Potential signs of long-lasting problems for lowachieving students. Retrieved on May 9, 2020, from https://hechingerreport.org/five-years-after-common-core-a-mysterious-spike-infailure-rate-among-ny-high-school-students/.

Bartholomew, A., Papay, C., McConnell, A., \& Cease-Cook, J. (2015). Embedding Secondary Transition in the Common Core State Standards. Teaching Exceptional Children, 47(6), 329-335. doi:10.1177/0040059915580034

Black, P. \& William, D. (1998). In the black box: Raising standards through classroom assessment. Retrieved from Kappanmagazine.org on February 27, 2016.

Black, P., \& William, D. (2010). Inside the Black Box: Raising Standards through Classroom Assessment. Phi Delta Kappan, 92(1), 81-90. doi:10.1177/003172171009200119

Bintz, W. P., \& Dillard, J. (2007). Teachers as Reflective Practitioners: Examining Teacher Stories of Curricular Change in a 4th Grade Classroom. Reading Horizons: A Journal of Literacy and Language Arts, 47 (3). Retrieved from https://scholarworks.wmich.edu/readinghorizons/vol47/iss3/4

Boser, U. (2014). "Teacher Diversity Revisited: A New State-by-State Analysis." Center for American Progress 5: 1-10.

Butrymowicz, S. (2017). "Most colleges enroll many students who aren't prepared for higher education: At more than 200 campuses, more than half of incoming 
students must take remedial courses." Retrieved August 4, 2019, from https://hechingerreport.org/colleges-enroll-students-arent-prepared-highereducation/.

Caldwell, K. M. (2007). A Guide to Curriculum Design: The Implementation of Student Development for Levels K-12. Kyra M. Caldwell (Standard Copyright License)

Center for Online Education (2019). College Writing Guide. Retrieved July 29, 2019, from https://www.onlinecolleges.net/for-students/academic-writing-guide/.

City, E. A. (2009). Instructional rounds in education: a network approach to improving teaching and learning. Cambridge, Mass.: Harvard Education Press.

Common Core. (n.d.). Retrieved April 21, 2013 from www.commoncore.org

Creswell, J. W., \& Creswell, J. W. (2013). Qualitative inquiry and research design: choosing among five approaches (3rd ed.). Los Angeles: SAGE Publications.

Darling-Hammond, L., \& McCloskey, L. (2011). Assessment for learning around the world: What would it mean to be internationally competitive? In Ornstein, A. C., Pajak, E., \& Ornstein, S. B. (2011). Contemporary issues in curriculum ( $5^{\text {th }}$ ed., pp. 336-347). Boston: Pearson.

Danielson, Charlotte (2013). The framework for teaching. Retrieved from https://www.ode.state.or.us/wma/teachlearn/commoncore/danielson-2013-rubriconly.pdf February 22, 2020.

DeVellis, R. F. (2012). Scale development: theory and applications (3rd ed.). Thousand Oaks, CA: SAGE.

Disare M. (2017). 'Common Core' no more: New York moves to adopt revised standards with new name. Retrieved on May 9, 2020 from https://ny.chalkbeat.org/2017/9/11/21100905/common-core-no-more-new-yorkmoves-to-adopt-revised-standards-with-new-name.

East Ramapo Central School District. About us. Retrieved June 20, 2016 from http://www.ercsd.org/pages/East_Ramapo_CSD/District_Pages/About_East_Ram apo.

Ecker, A. J. (2016). Implementation science: From dangerous canyons to fields of dream. Lower Hudson RSE-TASC. 5, (8), May 2016.

EducationNext (2018). EdStat: \$18 Billion a Year is Spent on Professional Development for U.S. Teachers. Retrieved from https://www.educationnext.org/edstat-18-billion-yearspent-professional-development-u-s-teachers/ 
Eisner, E. W. (2009). What does it mean to say a school is doing well? In D. J. Flinders $\&$ S. J. Thornton (Eds.) The curriculum studies reader $\left(3^{\text {rd }}\right.$ ed., pp. 106-113). New York, NY: Routledge.

Elliot, P. (2013). Common core opposition leaves educators smarting. Community College Week. December 23.

Engage New York (EngageNY) (2012). Common Core Shifts. Retrieved from https://www.engageny.org/resource/common-core-shifts

Engage New York (EngageNY) (2013). Regents Exam. Retrieved from https://www.engageny.org/resource/regents-exams.

Engage New York (EngageNY) (2014). Spring 2014 Regents Examination in ELA (Common Core) Resources. Retrieved from https://www.engageny.org/resource/spring-2014-regents-examination-elacommon-core-resources.

Engage New York. Regents Exams. Retrieved from https://www.engageny.org/resource/regentsexams. June 20, 2016.

Fermin, L. (2015). "Survey: Most high school students feel unprepared for college, careers." Retrieved July 29, 2019, 2019, from https://edsource.org/2015/surveymost-high-school-students-feel-unprepared-for-college-careers/83752.

Flinders, D. J., \& Thornton, S. J. (2009). The curriculum studies reader (3rd ed.). New York: Routledge.

Fullan, M. (2001). The new meaning of educational change (3rd ed.). New York: Teachers College Press.

George, A. A., Hall, G. E., \& Steigelbauer, S. M. (2013). Measuring implementation in Schools: The Stages of Concern Questionnaire. Austin, TX: SEDL

George, C. (2015). The relationship between attitudes toward the "no child left behind" law and perceived levels of burnout among teachers in Berrien County, Michigan (Order No. 3684962). Available from ProQuest Dissertations \& Theses Global. (1660978194). Retrieved from https://search-proquestcom.ezproxy.andrews.edu/docview/1660978194?accountid=8313

Hall, G.E., Dirksen, D.J., \& George, A. A. (2013). Measuring implementation in schools: Levels of use. Austin, TX: SEDL 
Hall, G. E., \& Hord, S. M. (2011). Implementing change: patterns, principles, and potholes (3rd ed.). Boston: Pearson.

Hannah, D. \& Dempster, M. (2012). Psychology statistics for dummies. Chichester, West Sussex, England: Wiley

Hechinger Report (2016). What can be done about failing U.S. high schools? A look back and ahead. Retrieved from https://hechingerreport.org/what-can-be-doneabout-failing-u-s-high-schools-a-look-back-and-ahead/

Heifetz, R. A., \& Linsky, M. (2004). When leadership spells danger. Educational Leadership, 61(7), 33-37. Retrieved from $<$ Go to ISI >://WOS:000220687300007

Holloway, K. (2003). A measure of concern: Research-based program aids innovation by addressing teacher concerns. Tools for Schools. February/March

Johnson, M. M. (2017). Assigning More Writing -With Less Grading: check out four best practices for teaching writing that can help you improve student learning without creating a mountain of grading work. Retrieved from https://www.edutopia.org/article/assigning-more-writing-less-grading. February $16,2020$.

Johnson, R. S. (2002). Using data to close the achievement gap: how to measure equity in our schools. Thousand Oaks, Calif.: Corwin Press.

Main, L. F. (2012). Too much too soon? Common core math standards in early years. Early Childhood Education Journal, 40, 73-77.

Marshall, J.D., Sears, J.T., Allen, L.A., Roberts, P.A., \& Schubert, W.H. (2007). Turning Points in Curriculum (2nd ed.). Upper Saddle River, NJ: Pearson

Marshall, J. D. (2007). Turning points in curriculum: a contemporary American memoir (2nd ed.). Upper Saddle River, N.J.: Pearson/Merrill Prentice hall.

Martin, C. (2015). Power to Change the Teachers: Teachers are key to implementing the Common Core Standards. Retrieved from

https://www.usnews.com/opinion/knowledge-bank/2015/04/29/why-teachers-arekey-to-implementing-common-core-standards

Maxwell, R. J. \& Meiser, M. J. (2001). Teaching English in middle and secondary schools (3rd ed.). Upper Saddle River, N.J.: Pearson/Merrill Prentice hall.

McMillan, J. H. \& Sally Schumacher. (2010). Research in education: evidencebased inquiry. Seventh Edition. New York: Pearson Allyn and Bacon. 
McPartland, J. M., \& Schneider, B. (1996). Opportunities to learn and student diversity: Prospects and pitfalls of a common core curriculum. Sociology of Education, 6681. Retrieved from <Go to ISI>://WOS:A1996UQ98200005

Mohamud, A., \& Fleck, D. (2010). Alignment of Standards, Assessment and Instruction: Implications for English Language Learners in Ohio. Theory into Practice, 49(2), 129-136. doi:10.1080/00405841003626643

National Association of Special Education Teachers (NASET). (n.d.). Highly qualified teachers. Retrieved from https://www.naset.org/index.php?id=highlyqualiedteacher. May 26, 2019

New York City Department of Education (NYCDE) (n.d.) Yearly testing. Retrieved March 25, 2015 from http://schools.nyc.gov/Accountability/resources/testing/New+York+State+English+Lang uage+Arts+ (ELA) +Test.htm

New York City Department of Education (NYCDE) (n.d.) New York State English Language Arts Test (ELA). Retrieved from https://www.schools.nyc.gov/learning/in-our-classrooms/testing/ny-state-englishlanguage-arts

New York State Education Department (NYSED). (n.d.). Every Student Succeeds Act. Retrieved from http://www.nysed.gov/essa, February 16, 2020.

Office of State Assessments (OSA) (2018). New York State Education Department Test Development Process. Retrieved May 18, 2020. From http://www.p12.nysed.gov/assessment/teacher/testdevprocess.html.

Office of State Assessments (OSA) (2020). Regents Examination in English Language Arts. Retrieved February, 17, 2020 from https://www.nysedregents.org/hsela/118/reela12018-exam.pdf

Office of State Assessments (OSA) (2020). Regents Examination in English Language Arts. Retrieved from https://www.nysedregents.org/hsela/619/reela62019-exam.pdf. Retrieved February 17, 2020

Office of State Assessments (OSA) (2020). Regents Examination in English Language Arts. Retrieved May, 18, 2020 from https://www.nysedregents.org/hsela/120/reela12020-exam.pdf

Ornstein, A. C., Pajak, E., \& Ornstein, S. B. (2011). Contemporary issues in curriculu $\left(5^{\text {th }}\right.$ ed.). Boston: Pearson.

Ostashevsky, L. (2016). "Many who pass state high school graduation tests show up to college unprepared: So what do the exams, now being conducted in classrooms nationwide, actually measure?". Retrieved August 4, 2019, from 
https://hechingerreport.org/many-who-pass-state-high-school-graduation-testsshow-up-to-college-unprepared/

Phillips, B., \& Vandal, B. (2011). Standards: A golden opportunity for K-16 collaboration. Education Week, 20-23.

Pinar, F. W., Reynolds, W. M., Slattery, P; \& Taubman, P. M. (2008). Understanding curriculum. New York: Peter Lang.

Pinar, W. (2012). What is curriculum theory? (2nd ed.). New York; London: Routledge.

Polikoff, M. S. (2017). Is Common Core "Working"? And Where Does Common Core Research Go From Here? AERA Open. https://doi.org/10.1177/2332858417691749

Portney, L. G., \& Watkins, M. P. (2000). Foundations of clinical research: applications to practice (2nd ed.). Upper Saddle River, NJ: Prentice Hall.

Rock, D. (2008). SCARF: a brain-based model for collaborating with and influencing others. Retrieved June 11, 2019, from www.Neuroleadership.org.

Rogers, E. M. (2003). Diffusion of innovations (5th ed.). New York: Free Press.

Rudestam, K. E., \& Newton, R. R. (2015). Surviving your dissertation: a comprehensive guide to content and process (Fourth edition. ed.). Thousand Oaks, California: Sage Publication.

Rycik, J. A. (2014). Support continues to erode for Common Core Standards and Assessments.American Secondary Education. 42(3). Summer.

Santelises, S. B. (April 6, 2016). Are high schools preparing students to be college- and career-ready?. Retrieved July 29, 2019, from https://hechingerreport.org/are-highschools-preparing-students-to-be-college-and-career-ready/.

Sawchuk, S. (2012). Common standards present new frontiers for teaching and learning: Schools scramble to get educators ready for instructional changes. Education Week. 4-6.

Schiro, M. (2013). Curriculum theory: conflicting visions and enduring concerns (2nd ed.). Thousand Oaks, Calif.: SAGE Publications.

Schmidt, W. H., \& Prawat, R. S. (2006). Curriculum coherence and national control of education: issue or non-issue? Journal of Curriculum Studies, 38(6), 641-658. doi: 10.1080/00220270600682804

Schneider, M. K. (2015). Common core dilemma: who owns our schools? New York, NY: Teachers College Press. 
SEDL. (n.d.). Stages of Concern. Retrieved April 9, 2015 from https://sedl.org/cbam/stages_of_concern.html

Siskin, L. S. (2009). Outside the core: Accountability in tested and untested subjects. In D. J. Flinders \& S. J. Thornton (Eds.) The curriculum studies reader (3rd ed., pp. 318-326). New York, NY: Routledge

Sleeter, C. \& Stillman, J. (2009). Standardized knowledge in a multicultural society. In D. J. Flinders \& S. J. Thornton (Eds.) The curriculum studies reader (3rd ed., pp. 303-317). New York, NY: Routledge

Supovitz, J., Fink, R., \& Newman, B. (2016). From the inside in: Common Core knowledge and communication within schools. AERA Open, 2 (3), 1-18.

Troia, G. A., \& Olinghouse, N. G. (2013). The Common Core State Standards and Evidence-Based Educational Practices: The Case of Writing. School Psychology Review, 42(3), 343-357. Retrieved from <Go to ISI>://WOS:000325119000007

Ujifusa, A. (2013). Common-Core Hurdle: Calming jittery districts. Education Week, 33, 11,1 .

United Federation of Teachers. (n.d.). Retrieved May 25, 2019 from http://www.uft.org/category/faq/tenure

Wang, W. (2014). Teachers' Stages of Concern and Levels of Use of a curriculum innovation in China: A case study. International Journal of English Language Teaching, 1(1). doi: https://doi.org/10.5430/ijelt.v1n1p22

Wallender, J. (2014). The Common Core State Standards in American public education: Historical underpinnings and justifications. Delta Kappa Gamma Bulletin, 80(4), 7-11. Retrieved from http://search.ebscohost.com/login.aspx?direct=true\&db=a9h\&AN= 96688858\&site=ehost-live

Walpole, S. and M. C. McKenna (2004). The literacy coach's handbook: a guide to research-based practice. New York, Guilford Press.

Weingarten, R. (2016). A reset we need to get right. American Educator.

Wraga, W. G. (1999). The educational and political implications of curriculum alignment and standards-based reform. Journal of Curriculum and Supervision, 15(1), 4-25. Retrieved from http://www.ascd.org/publications/jcs/fall1999/The_Educational_and_Political_ Implications_of_Curriculum_Alignment_and_Standards-Based_Reform.aspx 


\section{ALOZIE AUGUSTINE OGBONNA}

Tel: 1-917-515-7889

alozie247@gmail.com

\section{PROFESSIONAL EXPERIENCE}

\section{Graduate Assistant}

Andrews University, Berrien Springs, Michigan, summer 2019-spring 2020

- Assisted in planning and teaching graduate courses to graduate students

\section{English and Speech Teacher}

Spring Valley High School, Spring Valley, New York, 2015-present

Pomona Middle School, Spring Valley, New York, 2004-2014

\section{English Teacher (General Education Program)}

Yeshivas Ohr Reuven, Spring Valley, New York, 2017-present

\section{English Teacher (General Education Program)}

Mesivta Maamar Mordechai (Yeshivas), Spring Valley, New York, 2016-2017

Health Teacher, 2002-2004

John Philip Sousa Middle School (MS 142)—NYC Dept. of Education

Clinical/Administrative Assistant, 1998-2002

Our Lady of Mercy Medical Center

- Performed a variety of clinical/administrative duties

- Worked successfully in collaboration with other staff members in a variety of special assignments

English Language Teacher and Assistant Academic Dean, 1997-1998.

Adventist Secondary Technical College, Owerri-nta, Nigeria

\section{EDUCATION}

PhD. in Curriculum and Instruction (Candidate)

Andrews University, 2012-Present

Dissertation Title: “Teachers' Implementation of and Stages of Concern Regarding English Language Arts (ELA) Common Core State Standards (CCSS) in New York State"

\section{Certificate in Advanced Educational Leadership (CAEL)}

Harvard University School of Graduate Education, 2020

\section{MA in Educational Leadership and Administration}

New York University, 2006

\section{MA in Health Education and Promotion}


Lehman College, 2002

\section{Postgraduate Diploma in Education (PGDE)}

Abia State University, 2000

\section{BA in Theology/ English/French}

Andrews University, 1995

\section{LICENSES:}

NYS School Building Leader (Certification in process)

NYS English Language Arts (Permanent)

NYS Trainer: Child Abuse Identification and Reporting

NYS Health (Permanent)

\section{PROFESSIONAL DEVELOPMENT ACTIVITIES}

\section{Harvard Graduate School of Education}

“Driving Change: a module of the Certificate of Advanced Education Leadership" program,

September 23, 2019-December16, 2019

- Learned to examine what is known about the change process in school organizations,

understand how people experience disruption and change.

- Learned how to manage constraints and exploit opportunities in order to implement new practices with purpose and success.

- Explored the principles of change development, beginning with an understanding how I think about the problem I am trying to solve, and how I might approach working with others to develop a theory of action and to develop a strategy.

- Learned how to scan my educational setting, examining components such as culture, structure, systems, and stakeholders as I consider what I am trying to accomplish and what process might lead me there.

- Learned how effective change management targets and develops the various constituencies affected by the proposed change, including leaders at all levels of the organization itself and those outside the organization.

- Used tools and practiced concrete strategies to help me work with others to build awareness of the need for change, a shared mission, and a common agenda. 


\section{Harvard Graduate School of Education}

"Developing Myself: a module of the Certificate of Advanced Education Leadership" program, May

6-July27, 2019

- Learned the importance of intentional self-development and use a variety of tools to support that development.

- Practiced how deep listening, the ladder of inference, and testing big assumptions will help me leverage both relationships I form with others in the module, and existing relationships within in current contexts, as invaluable resources for my growth.

- Learned how the concepts and tools offered in the module will help me develop my capacity to diagnose and respond successfully to the complex demands inherent in systems level education leadership.

- Learned how to practice intentional self-development, identify a high-level leadership goal and make progress toward that goal.

- Learned how to apply the tools and practices used within the module's learning community to further my development within the context my workplace

\section{Harvard Graduate School of Education}

“Think-Tank on Global Education: Empowering Global Citizens,” May 16-17, 2019

- Participated in workshops that focused on testing and developing cutting-edge curriculum

to advance global competence in global studies, in classrooms, schools and districts

\section{Harvard Graduate School of Education}

"Leading for Excellence and Equity: a module of the Certificate of Advanced Education

Leadership" program, February 4 to April 28, 2019

- Learned about the ways that race impacts and effects the learning in our $\mathrm{K}$ through 12 and beyond

- Learned how to apply the Courageous Conversation Compass and Constructivist Listening Interviews in addressing race and equity issues

- Learned how to address the challenges of achieving excellence and equity for children and communities, for schools and organizations, here in America and across the world

- Learned and developed the skills to engage, appreciate, support, and lead diverse learning communities across the board to achieve equity and excellence for all students

\section{Harvard Graduate School of Education}


"Leading Learning: a module of the Certificate of Advanced Education Leadership" program,

September 24 to December 14, 2018

- Learned to analyze learning at multiple layers of the system, beginning with tasks in classrooms and then considering what adult learning needs to look like to support the learning of all children

- Learned and developed concrete skills in observing learning and teaching, planning effective meetings, discussing the intersection of race and learning, and using design thinking approaches to think more imaginatively and purposefully about learning throughout the system

\section{Bureau of Educational and Cultural Affairs, United States Department of States}

“Global Teaching Dialogue” Conference, July 27, 2018

- Learned best practices for globalizing curricula and implementing virtual exchanges from alumni of the Department's Teacher Exchange Programs and other global education leaders

- Participated in U.S. Diplomacy Center simulation workshop, a strategy for engaging students in difficult conversations

\section{Harvard Graduate School of Education}

“Think-Tank on Global Education: Empowering Global Citizens,” May 17-18, 2018

- Participated in workshops that focused on testing and developing cutting-edge curriculum

to advance global competence in global studies, in classrooms, schools and districts

\section{Strategic Education Research Partnership}

“Strategic Adolescent Reading Invention (STARI)" program, August 16-17, 2017

- Learned how to implement STARI, a literature-focused, Tier II intervention program for students in grades 6-9 who are reading 2-4 years below grade level. Using research-based practices and highly engaging texts, STARI addresses gaps in fluency, decoding, reading stamina, and basic comprehension, aiming to move struggling students to higher levels of proficiency at the end of one year. STARI actively engages students in discussions of cognitively challenging content aligned to the Common Core and other 21st century standards. (https://stari.serpmedia.org/)

\section{ADMINISTRATIVE AND COMMUNITY SERVICE POSITIONS}




\section{East Ramapo Central School District}

Leadership in Action (Member), 2018

- Participated in the district's strategic improvement meetings with the district administrators

\section{Clifford University Foundation, Inc.}

Founding Member and Administrative Secretary, 2018-present

- Schedule and prepare the agendas for teleconferences

- Work with the Fundraising Committee in planning and implementing fundraising events

- Serve as a liaison between the foundation and Clifford University Cabinet

\section{Spring Valley High School, East Ramapo Central School District}

School Leadership Team (Member), 2019-present

- Participated in developing and strategizing for implementation of the School Improvement Plan (SIP)

\section{Pablo Casals Middle School 181}

PA Vice President, 2011-2014

- Presided at PA meetings in the absence of the president

- Collaborated with the president in planning and conducting parent association meetings

- Collaborated with the president in organizing student enrichment academic and social programs

- Participated in meetings with the school administration in making administrative decisions, hiring and discharging of employees

\section{Oakview Academy (of the Seventh-day Adventists)}

School Board Member, 2007- Present

- Participate in the school board policy and decision-making

\section{Greater New York Society for Public Health Education, Inc. (GNYSOPHE)}

Immediate Past-President, 2006-2007

- Advised the President on administrative and policy matters

- Coordinated the appointment and election of officers

Greater New York Society for Public Health Education, Inc.(GNYSOPHE) 
President, 2005-2006

- Presided at board and membership meetings

- Represented the chapter at national events

- Implemented the organization's strategic plans

- Delegated responsibilities to the organization's officials

- Prepared documents for chapter re-designation in consonance with the national SOPHE guidelines.

Pomona Middle School, Suffern, New York

Internship in Educational Administration and Leadership, 2005

- Participated in school cabinet meetings

- Participated in planning and administration of field tests

- Participated in reviewing the school's strategic plan

- Participated in organizing and implementing staff development workshops

\section{Society for Public Health Education (SOPHE)}

Member, Continuing Education Committee, 2004-2007

- Reviewed a variety of continuing education programs and college health education courses

\section{Greater New York Society for Public Health Education (GNYSOPHE)}

President-Elect, 2004-2005

- Networked with other public health agencies for program collaboration

- Presided at board meetings, strategic planning meetings and membership meetings in the absence of the president

- Planned and implemented chapter programs

\section{Greater New York Society for Public Health Education, Inc. (GNYSOPHE)}

Continuing Education Committee Chair, 2003-2004

- Acted as the coordinator for all CE questions and problems and interpreted the CE policy for the Chapter

- Acted as the liaison to the National CE Committee

- Participated in all National CE calls and meetings

- Designed goals and objectives for the Chapter CE Committee that are based on the National CE Committee goals and objectives

- Interpreted CE policy and procedures and ensured that the policies are adhered to and that all materials required are submitted to the national office on time and in the format required

- Maintained chapter records of all CE events and acted as the resource person for all local CE questions

- Worked with another committee member to work with and be a part of the program planning committees for local CE events and local co-sponsored events 


\section{Sterling Montessori Schools (Nursery \& Primary), Nigeria}

Founder and Principal, 1996

- Worked with the department of education for approval of the school to provide quality education to underprivileged children in the community

- Hired teachers and implemented necessary professional development support programs

- Educated parents during PTA meetings on the need to sacrifice for the education of their children, especially girls.

\section{ACADEMIC PRESENTATION}

\section{Andrews University}

Teaching and Learning Conference, 2015

- "What Was Life Like During the Harlem Renaissance?" (A first-place winner presentation)

\section{Bronx Community College, New York}

Fifth Annual Health Education Career Forum, 2003

- "Health Education: An Enduring Career"

\section{Special Skills and Technology Experience}

- Online instruction development and delivery

- Web site development and management

- Graphic designing

- Various computer applications and statistical software such as PowerPoint, Adobe Illustrator, Corel Draw, Excel, Intuit QuickBooks, SPSS, AMOS, etc. 